Portland State University

PDXScholar

7-28-1986

\title{
The Chemistry of Novel Chromium(IV) Systems and Fluorinated Hypochlorites
}

Joseph Onuorah Udeaja

Portland State University

Follow this and additional works at: https://pdxscholar.library.pdx.edu/open_access_etds

Part of the Chemistry Commons

Let us know how access to this document benefits you.

\section{Recommended Citation}

Udeaja, Joseph Onuorah, "The Chemistry of Novel Chromium(IV) Systems and Fluorinated Hypochlorites" (1986). Dissertations and Theses. Paper 3652.

https://doi.org/10.15760/etd.5536

This Thesis is brought to you for free and open access. It has been accepted for inclusion in Dissertations and Theses by an authorized administrator of PDXScholar. Please contact us if we can make this document more accessible: pdxscholar@pdx.edu. 
AN ABSTRACT OF THE THESIS OF Joseph Onuorah Udeaja for the Master of Science in Chemistry presented July 28, 1986.

Title: The Chemistry of Novel Chromium(IV) Systems and Fluorinated Hypochlorites.

APPROVED BY MEMBERS OF THE THESIS COMMITTEE:

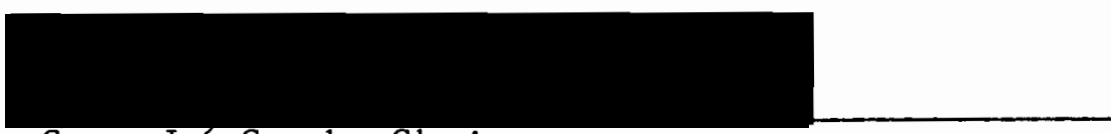

Gary d. Gard, Chairman

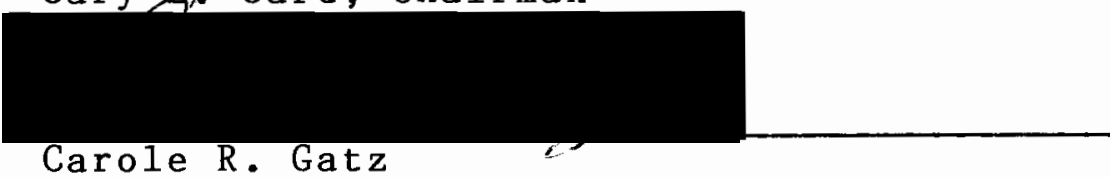

Carole R. Gatz

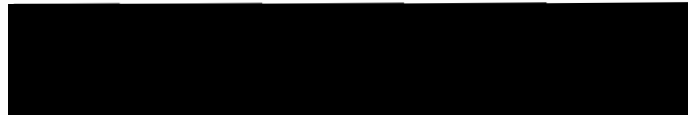

Morris B. Silverman

Chromium(IV) has been of interest for some time because of its role as an intermediate in chromic oxidation reactions. Since there are not a great number of stable tetravalent chromium complexes known, and the use of such species as oxidizing agents has not been widely explored, the preparation, isolation and characterization of new stable tetravalent chromium species may allow chemists the opportunity to more fully 
understand the role which tetravalent chromium plays in oxidation reactions. The present study thus involves the synthesis of $\mathrm{Cr}\left(\mathrm{OC}_{4} \mathrm{H}_{9}\right)_{4}$ and other $\mathrm{Cr}(\mathrm{IV})$ derivatives and the use of $\mathrm{Cr}\left(\mathrm{OC}_{4} \mathrm{H}_{9}\right)_{4}$ in oxidative reactions with selected fluorinated alcohols. Interestingly, the reaction of fluorinated alcohols with $\mathrm{Cr}\left(\mathrm{OC}_{4} \mathrm{H}_{9}\right)_{4}$ or $\mathrm{Cr}\left(\mathrm{NEt}_{2}\right)_{3}$ was found to be a useful method for preparing similar products.

The reaction of fluorinated hypochlorites, $\mathrm{CF}_{3} \mathrm{OCl}$ and $\left(\mathrm{CF}_{3}\right)_{3} \mathrm{COCl}$, have been extensively studied; both the oxidative displacement and addition reactions of F-tert-butyl hypochlorite with transition and post-transition metal chlorides have been studied by Dr. Gard's group at Portland State University and Dr. Shreeve's group at University of Idaho. We have now extended the chemistry of fluorinated hypochlorite to include the heptafluoroisopropyl hypochlorite, $i-C_{3} F_{7} 0 \mathrm{Cl}$, and we report the preparation of a new fluorinated hypochlorite, perfluoro-tertiary-amyl hypochlorite, $\mathrm{CF}_{3} \mathrm{CF}_{2} \mathrm{C}\left(\mathrm{CF}_{3}\right)_{2} \mathrm{OCl}$, which is an important addition to the fluorinated hypochlorite chemistry studied in Dr. Gard's laboratory at Portland State University.

Analytical data, infrared and nmr spectra are presented in order to support the proposed structures of the new compounds formed. 
THE CHEMISTRY OF

NOVEL CHROMIUM(IV) SYSTEMS

AND

FLUORINATED HYPOCHLORITES

by

JOSEPH ONUORAH UDEAJA

A thesis submitted in partial fulfillment of the requirements for the degree of

\author{
MASTER OF SCIENCE \\ in \\ CHEMISTRY
}

Portland State University

1986 
TO THE OFFICE OF GRADUATE STUDIES AND RESEARCH:

The members of the Committee approve the thesis of Joseph Onuorah Udeaja presented July 28, 1986.

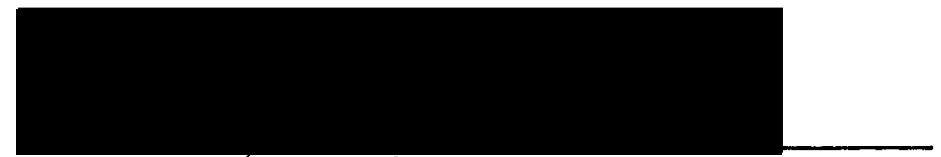

Gary $/$. Gard, Chairman

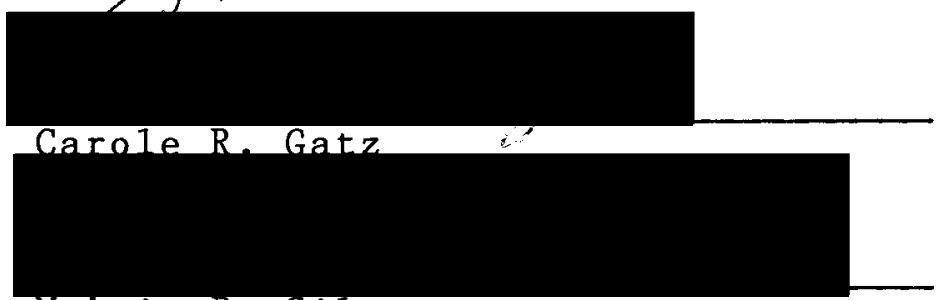

Morris B. Silverman

APPROVED :
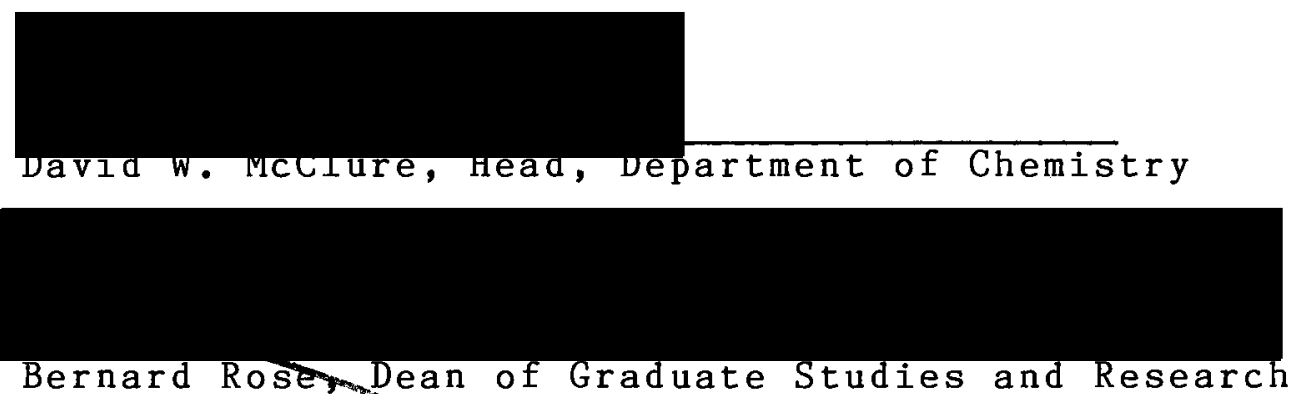


\section{ACKNOWLEDGEMENTS}

The author extends gratitude to Dr. Gary L. Gard for his assistance, guidance and patience; to Dr. R. Sheets for obtaining the NMR spectra; to Robin J. Terjeson for help in interpreting the NMR spectra and also for supplying the $\mathrm{SF}_{5}$-olefins. Additional appreciation is extended to all the group in Dr. Gard's laboratory. In many ways you all helped to make my work possible. 
TABLE OF CONTENTS

PAGE

ACKNOWLEDGEMENTS

LIST OF TABLES . . . . . . . . . . . . . . . vi v

LIST OF FIGURES . . . . . . . . . . . . . . . vii

CHAPTER

I INTRODUCTION • • . • . . . . . . . . . . I

A. Chromium (IV) Systems . . . . . . 1

B. F1uorinated Hypochlorites... . . 19

I I EXPERIMENTAL METHODS . . . . . . . . . 32

Apparatus . . . . . . . . 32

Physical Methods . . . . . . . 37

Reagents . . . . . . . . . 38

III SYNTHESIS OF $\mathrm{Cr}(\mathrm{IV}) / \mathrm{Cr}(\mathrm{III})$ COMPOUNDS $• \cdot$. 44

Introduction . . . . . . . . . . 44

Experimental . . . . . . . . 50

Infrared Spectra........ . 58

Summary/Conclusion . . . . . . 62

IV SYNTHESIS OF F-HYPOCHLORITES . . . . . . 66

Introduction . . . . . . . . . 66 
CHAPTER

PAGE

Experimental . • . . . . . . . 70

Elemental Analysis • • • . • . • • . 77

Mass Spectra . . . . . . . . . 77

Infrared Spectra . . . . . . . . 77

Nuclear Magnetic Resonance Spectra • . 88

Summary/Conclusion . • • • • • • • • 94

REFERENCES CITED • • • • • • • • • • • • • • • • • 96

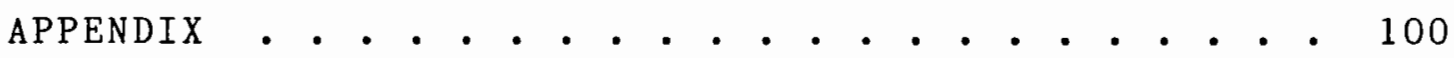


I Known Chromyl Compounds $\left(\mathrm{Cr}^{+6}\right.$ systems $) \cdot .2$

II Some $\mathrm{Cr}^{+5}$ Systems . . . . . . . . . 5

II Some Known $\mathrm{Cr}^{+4}$ Compounds \& Their Synthetic Pathways . . . . . . . . . . . . . 7

IV Physical Properties of Cr(IV)-t-alkoxides . . 11

$V$ Reactions Discussed in Chapter III . . . . 18

VI Some Known reactions of F-t-butyl Hypochlorites . . . . . . . . . . . 23

VII Some Reactions of F-t-butyl Hypochlorites Studied in Dr. Gard's Laboratory at PSU . . 24

VIII Reactions of $\left(\mathrm{CF}_{3}\right)_{3} \mathrm{COHgCl} \cdot$. . . • • • 25

IX Reactions Discussed in Chapter IV . . . . 30

$X$ Results of Reactions of $\mathrm{Cr}\left(\mathrm{OC}_{4} \mathrm{H}_{9}\right)_{4}$ with

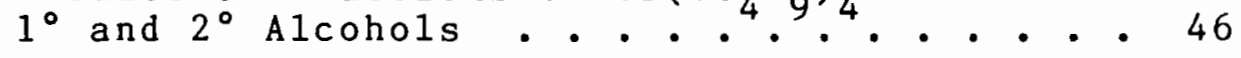

XI Oxidation of Alcohols \& Selected Metal and Non-metal Ions . . . . . . . . . . . 48

XII Infrared Absorption Bands for $\mathrm{Cr}$ (IV)/Cr(III) Compounds . . . . . . . . . . . . 59

XII Mass Spectra Data for the F-Hypochlorite Compounds... . . . . . . . . . . 78

XIV Infrared Absorption Bands for F-Hypochlorite Compounds . . . . . . . . . . . 86

XV NMR Chemical Shifts for F-Hypochlorite Compounds... . . . . . . . . . . 9 92

XVI NMR Coupling Constants for F-Hypochlorite Compounds . . . . . . . . . . . . . 93 


\section{LIST OF FIGURES}

FIGURE

PAGE

1. Pyrex-glass Vacuum Manifold . . . . . . 33

2. Fluorine Vacuum Line . . . . . . . . 35 


\section{CHAPTER I}

\section{INTRODUCTION}

\section{A. CHROMIUM IV COMPOUNDS}

For a number of years, Dr. Gard's research group at Portland State University has been studying the synthesis and properties of chromium in its high valent states of $+4,+5$, and $+6(1,2,3)$. For example, in the +6 state the following new oxidants are known, see Table I.

With $\mathrm{Cr}^{+5}$ the following systems have been studied, see Table II.

Interesting structural studies have also been carried out in conjunction with Dr. Kenneth Hedberg's group at Oregon State University and Dr. Roger Willet's group at Washington State University. In particular, the structures of $\mathrm{CrOF}_{3}$ and $\mathrm{CrF}_{5}$ have been elucidated and reported $(5,6,7)$.

It thus became of interest to expand our studies of high valent chromium compounds to include the +4 oxidation state. It is interesting to note that the +4 oxidation state has been relatively uncommon for chromium. Some of the known compounds in this group include: 


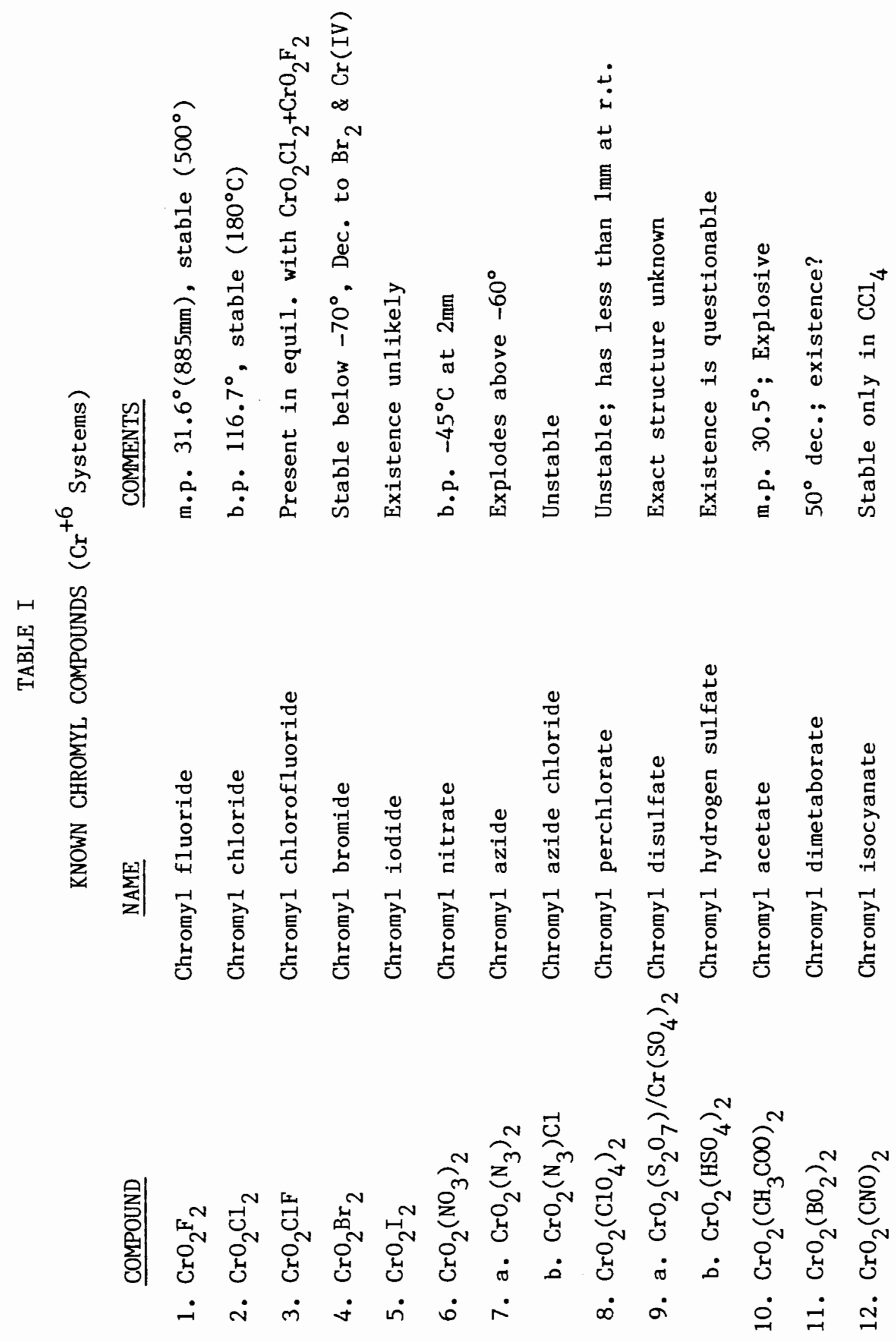



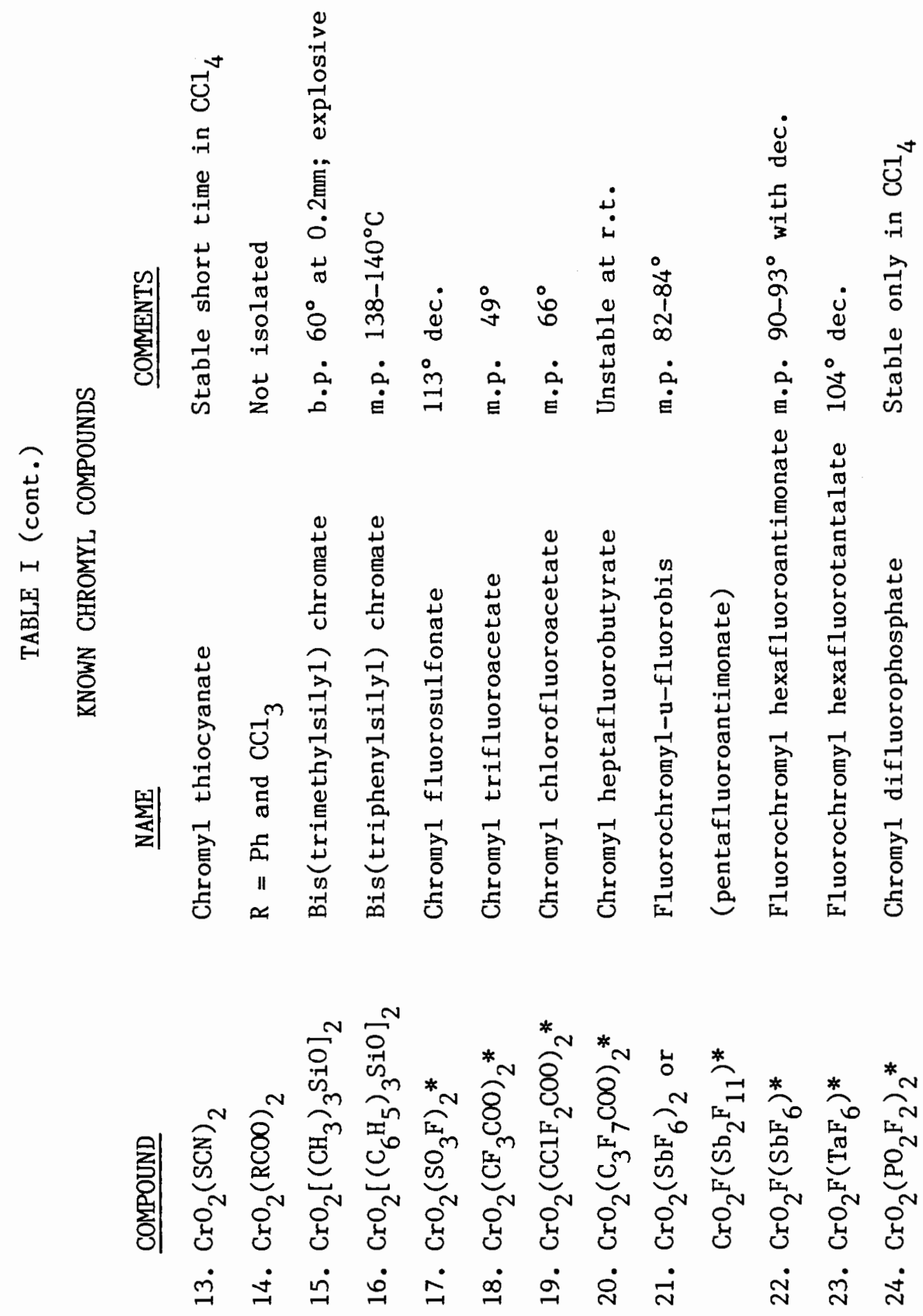


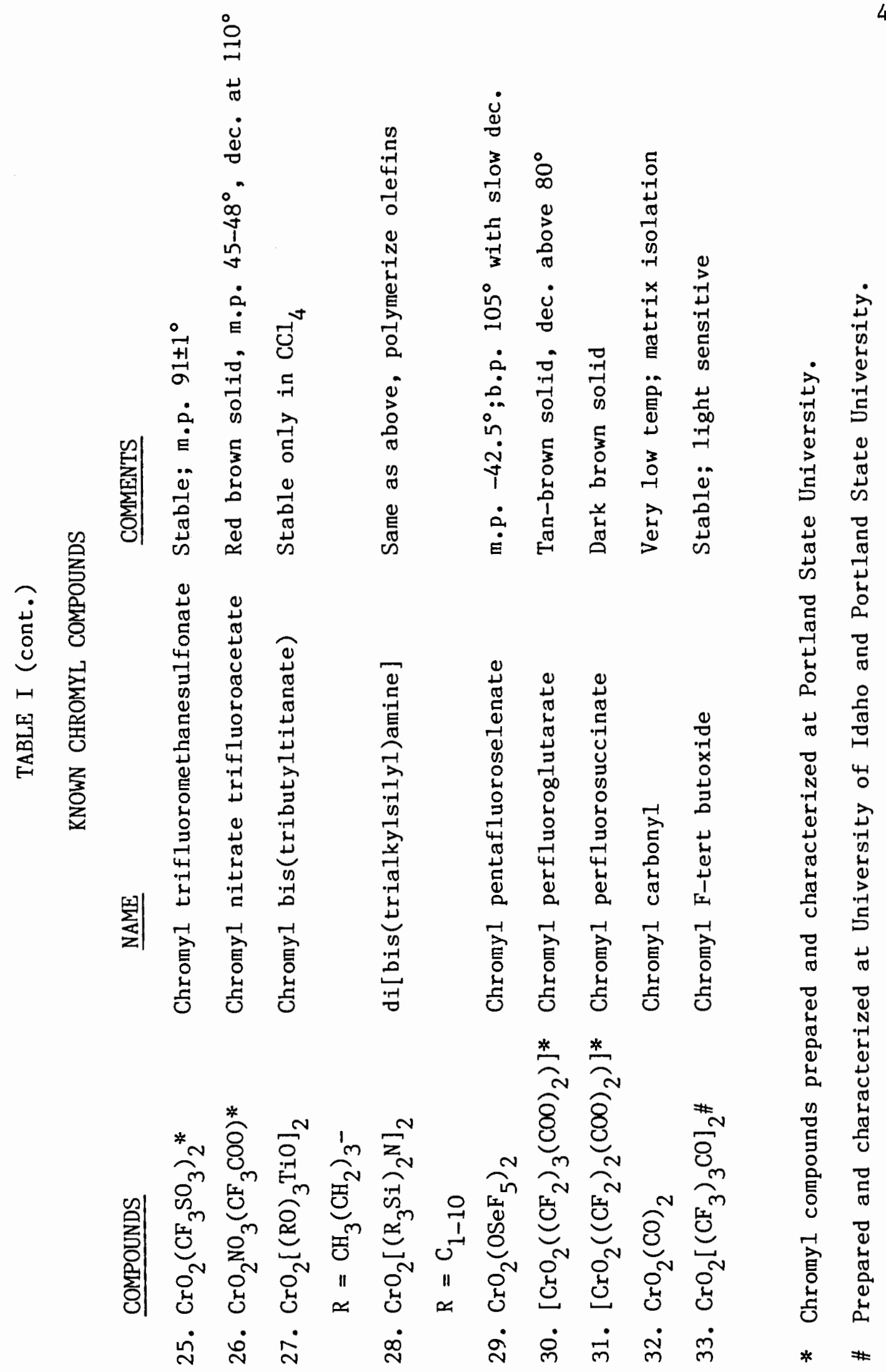


TABLE II

SOME $\mathrm{Cr}^{+5}$ SYSTEMS

REACTANTS

Cr (V) PRODUCTS

$\begin{array}{lll}\mathrm{Ag}_{2} \mathrm{Cr}_{2} \mathrm{O}_{7}+\mathrm{BrF}_{3} & --> & 2 \mathrm{AgCrOF}_{4} \\ \mathrm{CrF}_{3}+\mathrm{F}_{2} & -\rightarrow & \mathrm{CrF}_{5} \text { (7) }\end{array}$

$\mathrm{CrO}_{2} \mathrm{Cl}_{2}+2 / 3 \mathrm{BCl}_{3}-\rightarrow \mathrm{CrOCl}_{3}$

$\mathrm{XeF}_{2}+2 \mathrm{CrO}_{2} \mathrm{Cl}_{2} \quad-->\mathrm{CrOF}_{3}$

$\mathrm{CrOF}_{3}+\mathrm{KF}+\mathrm{HF} \quad-->\quad \mathrm{KCrOF}_{4}$ 
(i) the halides, $\mathrm{CrX}_{4}(\mathrm{X}=\mathrm{F}, \mathrm{C} 1, \mathrm{Br})(10)$

$$
M^{\prime} \mathrm{CrF}_{5} \text { and } M^{\prime}{ }_{2} \mathrm{CrF}_{6}\left(M^{\prime}=\mathrm{K}, \mathrm{Rb}, \mathrm{Cs}\right)
$$

(ii) the dialkylamides, $\mathrm{Cr}_{\left(\mathrm{NR}_{2}\right)_{4}}(\mathrm{R}=\mathrm{Et}, \operatorname{Pr}, \mathrm{MePr})$

(iii) the mixed oxides, $\mathrm{M}_{4}{ }_{4} \mathrm{CrO}_{6}$ and $\mathrm{M}_{3} \mathrm{CrO}_{5}\left(\mathrm{M}^{\prime \prime}=\mathrm{Sr}, \mathrm{Ba}\right)$

(iv) the alkoxides, $\mathrm{Cr}(\mathrm{OR})_{4}\left(\mathrm{R}=\mathrm{t}-\mathrm{Bu},-\mathrm{SiEt}_{3},-\mathrm{C}\left(\mathrm{CH}_{3}\right)_{2} \mathrm{Et}\right.$,

$$
\left.-\mathrm{CEt}_{3}\right)
$$

Table III summarizes the list of some of the known Cr(IV) compounds and their suggested synthetic pathways.

In $\mathrm{CrO}_{2}$, the presence of $\mathrm{Cr}(\mathrm{IV})$ has recently been questioned and it has been suggested that it is a $\mathrm{Cr}(\mathrm{III})-\mathrm{Cr}(\mathrm{VI})$ compound, $(\mathrm{CrO})_{2} \mathrm{CrO}_{4}(10)$. The tetrabromide and tetrachloride are very unstable and appear to exist on $1 y$ in the vapor state.

Chromium tetrafluoride. $\mathrm{CrF}_{4}$ is a very dark greenish-black solid, steel blue in the gas phase, which on exposure to moisture rapidly acquires a brown coating due to hydrolysis. The hydrolysis reaction:

$\mathrm{I}-14 \mathrm{H}_{2} \mathrm{O}+3 \mathrm{Cr}^{+4}--\rightarrow \mathrm{CrO}_{4}^{2-}+2 \mathrm{Cr}^{+3}+8 \mathrm{H}^{+}$(10) is similar for many $\operatorname{Cr}(I V)$ systems. It is surprisingly chemically inert and does not react with ammonia, sulfur dioxide, sulfur trioxide or pyridine(10). 
TABLE III

$\underline{\text { Reactants }}$

$\mathrm{Cr}+2 \mathrm{~F}_{2}$

$\mathrm{CrO}_{2} \mathrm{~F}_{2}$ (500-525 atm.)

$\mathrm{MCl}+\mathrm{CrF}_{4}+\mathrm{BrF}_{3}$

$$
(M=K, R b, C s)
$$

$2 \mathrm{CrCl}_{3}+\mathrm{Cl}_{2}$

$\mathrm{MCrO}_{4}+\mathrm{Cr}_{2} \mathrm{O}_{3}+5 \mathrm{M}(\mathrm{OH})_{2}$

$(\mathrm{M}=\mathrm{Ba}, \mathrm{Sr})$

$\mathrm{CrO}_{2} \mathrm{Cl}_{2}+\mathrm{O}_{2}(12-25$ atm.)

$\mathrm{CrCl}_{3} \cdot 3 \mathrm{THF}+4 \mathrm{neo}_{5} \mathrm{C}_{5} \mathrm{H}_{11} \mathrm{Li}$

$\mathrm{Cr}\left(\mathrm{N}(\mathrm{Et})_{2}\right)_{4}+4 \mathrm{t}-\mathrm{BuOH}$

\section{$\underline{\text { Cr (IV) Product }}$}

$\mathrm{CrF}_{4}$ (10)

$\mathrm{CrOF}_{2} \quad$ (14)

$\mathrm{MCrF}_{5} \quad(10)$

$2 \mathrm{CrCl}_{4}$

$3 \mathrm{M}_{2} \mathrm{CrO}_{4}$

$\mathrm{CrO}_{2}+\mathrm{Cl}_{2}$

$\mathrm{Cr}\left(\text { neo- } \mathrm{C}_{5} \mathrm{H}_{11}\right)_{4}$

$\mathrm{Cr}\left(\mathrm{OC}\left(\mathrm{CH}_{3}\right)_{3}\right)_{4}$ 
$\mathrm{CrF}_{4}$ is a stable compound prepared by passing fluorine directly over chromium(10).

$\mathrm{I}-2 \mathrm{Cr}+2 \mathrm{~F}_{2}-->\mathrm{CrF}_{4}$

On heating in vacuo at $100^{\circ}, \mathrm{CrF}_{4}$ sublimes with deposits of a bluish material on the cooler parts of the tube. The rate increases with higher temperature, for example, at $180^{\circ}$ and after 15-20 hours the entire sample had sublimed(10). On exposure to air, it is immediately coated with a brown oxide layer, and is responsible for the cinnamon color reported for the tetrafluoride by Von Wartenberg ( 10$)$.

Chromium oxide difluoride. $\mathrm{CrOF}_{2}$ is a brown-black solid (brown when in a finely divided state) and is insoluble in water, in acids $\left(\mathrm{HCl}, \mathrm{HF}, \mathrm{HNO}_{3}\right)$, in bases $\left(\mathrm{NH}_{4} \mathrm{OH}, \mathrm{NaOH}, \mathrm{KOH}\right)$, and in common organic solvents $(14)$. It is quantitatively obtained as a decomposition product of chromyl fluoride: (14)

$\mathrm{I}-3 \quad \mathrm{CrO}_{2} \mathrm{~F}_{2}--\rightarrow \mathrm{CrOF}_{2}+\frac{1}{2} \mathrm{O}_{2}$

$\mathrm{CrOF}_{2}$ is stable at $1600^{\circ}$ in vacuo, but in a nickel crucible at atmospheric pressure and at $1600^{\circ}$ it is converted to $\mathrm{Cr}_{2} \mathrm{O}_{3}$ and presumably NiF $2(14)$. The magnetic susceptibility of $\mathrm{CrOF}_{2}(1.1 \mathrm{BM})$ is noticeably lower than that calculated for a Cr(IV) state (theoretical: 2.8BM)(14). This is presumably caused by $\mathrm{CrOF}_{2}$ not being magnetically dilute. A similar magnetic effect has been 
observed in other transition metal oxides and fluorides with a probable $d^{2}$ configuration for the metal constituent (14).

Chromium tetradiethylamide. $\operatorname{Cr}\left(\mathrm{NEt}_{2}\right)_{4}$ was discovered as a product of a remarkable valence disproportionation of Chromium (III) diethylamide(11):

$\mathrm{I}-4 \quad \mathrm{CrCl}_{3}+3 \mathrm{LiNR}_{2} \quad-->\mathrm{Cr}\left(\mathrm{NR}_{2}\right)_{3}+3 \mathrm{LiCl}$

$\mathrm{I}-5 \quad 2 \mathrm{Cr}\left(\mathrm{NR}_{2}\right)_{3} \quad-->\quad \mathrm{Cr}\left(\mathrm{NR}_{2}\right)_{2}+\mathrm{Cr}\left(\mathrm{NR}_{2}\right)_{4}$

The disproportionation step (Equation I-5) is facilitated by the volatility of the tetrakis(diakylamide) which can easily be removed under vacuum leaving behind the polymeric chromium(II) dialkylamide. The dialkylamides are air and moisture sensitive, soluble in common organic solvents, and react with primary and secondary alcohols to give the chromium(III) alkoxides and the corresponding aldehydes and ketones in unknown yields (11).

$\mathrm{I}-62 \mathrm{Cr}\left(\mathrm{NEt}_{2}\right)_{4}+7 \mathrm{RR}^{\prime} \mathrm{CHOH} \quad-->2 \mathrm{Cr}\left(\mathrm{OCHRR}^{\prime}\right)_{3}+$ $\mathrm{RR}^{\prime} \mathrm{C}=\mathrm{O}+8 \mathrm{Et}_{2} \mathrm{NH}$

With tertiary alcohols or trialkylsilanols, the tetra(alkoxide) is formed(11). 
$\mathrm{I}-7 \mathrm{Cr}\left(\mathrm{NEt}_{2}\right)_{4}+4 \mathrm{R}^{\mathrm{t}} \mathrm{OH} \quad-->\mathrm{Cr}\left(\mathrm{OR}^{\mathrm{t}}\right)_{4}+4 \mathrm{Et}_{2} \mathrm{NH}$

The compounds are all paramagnetic but exhibit no ESR to at least $98^{\circ} \mathrm{K}$ and they appear to be distorted from tetrahedral to Dad stereochemistry(15).

Chromium(IV) alkoxides. The alkoxides, especially, the volatile blue solid $\mathrm{Cr}\left(\mathrm{OBu}^{\mathrm{t}}\right)_{4}$, are the best authenticated and characterized quadrivalent chromium(IV) compounds. A wide variety of methods is available for the preparations. These include;

(i) the action of di-t-butyl peroxide on dibenzene chromium(13)

(ii) alcoholysis of tetrakis(dialkylamides)(11,12)

(iii) oxidation of $\mathrm{Cr}\left(\mathrm{OBu}^{t}\right)_{3}$ in the presence of t-butyl alcohol by various reagents, e.g. $\mathrm{Bu}_{2}^{\mathrm{t}} \mathrm{O}_{2}, \mathrm{CrO}_{2}\left(\mathrm{OBu}^{\mathrm{t}}\right), \mathrm{Pb}(\mathrm{OAC})_{4}, \mathrm{Br}_{2}$, or $\mathrm{O}_{2}$ (12)

(iv) from the reaction of $\mathrm{CrCl}_{3} 3 \mathrm{THF}$ with $\mathrm{NaOBu}{ }^{\mathrm{t}}$ and $\mathrm{CuCl}$ (12)

(v) addition of cuprous chloride to a suspension of LiCr $\left(\mathrm{OBu}^{\mathrm{t}}\right)_{4}$ in refluxing tetrahydrofuran

The first method was used originally to prepare $\mathrm{Cr}\left(\mathrm{OBu}^{\mathrm{t}}\right)_{4}$ and a number of pure tetra-t-alkoxides were prepared through method two. 
Benzene is preferred as the solvent since it aids in the removal of tertiary-butyl alcohol through the formation of an azeotrope.

Cr(IV) alkoxides are $d^{2}$ systems with a characteristic blue color ascribed to absoption in the $15,000 \mathrm{~cm}^{-1}$ region interpreted in terms of the three d-d transitions expected for a tetrahedral $d^{2}$ complex:

${ }^{3} \mathrm{~T}_{2}(\mathrm{~F})<--{ }^{3} \mathrm{~A}_{2}(\mathrm{~F})\left(9100 \mathrm{~cm}^{-1}\right)$;

${ }^{3} \mathrm{~T}_{1}(\mathrm{~F})<--{ }^{3} \mathrm{~A}_{2}\left(15,200 \mathrm{~cm}^{-1}\right) ;{ }^{3} \mathrm{~T}_{1}(\mathrm{P})<--{ }^{3} \mathrm{~A}_{2}\left(25,000 \mathrm{~cm}^{-1}\right)$ with $10 \mathrm{Dq}=9430 \mathrm{~cm}^{-1}$ and $B=795 \mathrm{~cm}^{-1}$ (16). However, the lowest energy bands were doublets $(8700,9500$, and 13,700, $15,750 \mathrm{~cm}^{-1}$ ) suggesting a lowering in symmetry to $D_{2} \mathrm{~d}$, which would split the $T$ terms(16).

Bradley et a1.(12) has prepared several t-amyl alkoxides and the mixed alkoxides. Table IV lists these compounds along with their physical properties(12).

TABLE IV

Physical properties of $\operatorname{Cr}($ IV)-t-alkoxides (12)

Compound ${ }^{*}$

$\mathrm{Cr}\left(\mathrm{OCMe}_{2} \mathrm{Et}\right)_{4}$

$\mathrm{Cr}\left(\mathrm{OCMeEt}_{2}\right)_{4}^{4}$

$\mathrm{Cr}\left(\mathrm{OCEt}_{3}\right)_{4}$

$\mathrm{Cr}\left(\mathrm{OSiEt}_{3}\right)_{4}$
$\frac{M P}{36-37} \quad \frac{\text { Volatility }}{66 / 2.7}$

1 iquida

liquid

liquid

viscous

liquid
$110 / 2.5$

$135 / 2.5$

decomp.

decomp.
$\frac{\mathrm{IR}}{623} \frac{\mathrm{c}}{2.82}$

$\begin{array}{ll}633 & 2.79\end{array}$

$625 \quad 2.79$

a 1iquid at $20^{\circ}$; b bath temp, ${ }^{\circ} \mathrm{C} / \mathrm{mm}_{-1}$

c Cr-0 stretching mode $\mathrm{v}_{3}\left(\mathrm{t}_{2}\right), \mathrm{cm}^{-1}$.

* All were royal blue in color. 
They are all low-melting solids, paramagnetic, and can be easily distilled in vacuo; molecular-weight determinations (cryoscopic in cyclohexane) showed that they are monomeric(12). Thermochemical measurements(17) have shown that for $\mathrm{Cr}\left(\mathrm{OBu}^{\mathrm{t}}\right)_{4} \Delta \Delta_{\mathrm{f}}{ }_{\mathrm{f}}=-305 \mathrm{kcal} / \mathrm{mole}$, implying considerable thermodynamic stability. Also it was noticed, in the spectroscopic work (UV region) with dilute solutions in cyclohexane, that $\mathrm{Cr}\left(\mathrm{OBu}^{\mathrm{t}}\right)_{4}$ was less readily hydrolyzed than $\left.\mathrm{Ti}_{(\mathrm{OBu}}{ }^{\mathrm{t}}\right)_{4}$. This hydrolytic effect can be related to a kinetic effect with the ligand-field stabilized $d^{2}$ system for $\operatorname{Cr}(I V)$ having a higher activation energy to nucleophilic attack by water than the ${ }^{\circ}$, Ti(IV) system(12).

$\mathrm{Cr}\left(\mathrm{OBu}^{\mathrm{t}}\right)_{4}$ shows a noticeably slow alcoholysis and a mixed alkoxide $\mathrm{Cr}\left(\mathrm{OBu}^{\mathrm{t}}\right)_{2}\left(\mathrm{OCMe}_{2} \mathrm{Et}_{2}\right)_{2}$ was obtained from a reaction involving $\mathrm{Cr}\left(\mathrm{OBu}^{\mathrm{t}}\right)_{4}$ and $t$-pentyl alcohol(12). The $\operatorname{Cr}(I V)$ system retains a high oxidizing potential $\left(E^{\circ}=+2.1\right.$ Volts $)$ and attempts to prepare primary or secondary alkoxides led to oxidation of the ligand with formation of the $\operatorname{Cr}($ III) alkoxide, aldehydes or ketones, e.g. (12).

$\mathrm{I}-82 \mathrm{Cr}\left(\mathrm{OBu}^{\mathrm{t}}\right)_{4}+7 \mathrm{RCH}_{2} \mathrm{OH} \rightarrow--2 \mathrm{Cr}\left(\mathrm{OCH}_{2} \mathrm{R}\right)_{3}+\mathrm{RCHO}$ $+8 \mathrm{Bu}^{\mathrm{t}} \mathrm{OH}$

Similarly, attempts to synthesize $\operatorname{Cr}(\mathrm{IV})$ compounds in 
higher co-ordination states by exchange reactions with chelating ligands, e.g. acetic anhydride, hexafluoroacetone, always led to redox reactions and formation of $\operatorname{Cr}($ III) tris-chelates(12). For example, the reaction of $\mathrm{Cr}\left(\mathrm{OBu}^{\mathrm{t}}\right)_{4}$ with hexafluoroacetylacetone forms the chromium(III) complex, t-butyl alcohol and hexafluoroacetone; acetic anhydride reacted to yield acetone, and t-butyl alcohol. The stability of $\operatorname{Cr}$ (IV) tertiary butoxide is clearly due to the absence of alpha $\mathrm{CH}$ bonds and this also explains the ready formation of the triethylsilyloxy derivative, $\operatorname{Cr}\left(\mathrm{OSiEt}_{3}\right)_{4}(12)$.

Genera1 Overview of the Chemistry of Transition Metal Alkoxides as Related to Chromium Alkoxides.

Transition metal alkoxides have been known for a long time but an intensive study of their chemistry has only been recently attempted; most of these studies have centered around the preparation and characterization of the transition metal alkoxides(15).

Physica1 properties. The tendency to expand their coordination by polymerization through alkoxy bridging is a characteristic feature of the alkoxides(15). 
The degree of polymerization of the solids seems to depend on the coordination number of the metal and the steric bulk of the surrounding groups. Thus, the more highly branched the alkoxy group, the lower the degree of polymerization(15). The monomeric nature of t-butoxides, in many cases, is ascribed to large steric effect(15). A similar trend is observed in the alkoxides; the lower, less sterically hindered alkoxides are less volatile due to a higher degree of polymerization. The alkoxides do not seem to form many coordination compounds with donor molecules such as alcohols or amines(15). The few adducts known include:

$$
\begin{array}{lc}
\mathrm{Ti}\left(\mathrm{OBu}^{\mathrm{i}}\right)_{4} \cdot \mathrm{Bu}^{\mathrm{i} O H} & \mathrm{Zr}\left(\mathrm{OPr}^{\mathrm{i}}\right)_{4} \cdot \mathrm{Pr}^{\mathrm{i} O H} \\
\mathrm{Zr}\left(\mathrm{OPr}^{\mathrm{i}}\right)_{4} \cdot \mathrm{C}_{5} \mathrm{H}_{5} \mathrm{~N}, & \mathrm{Ce}\left(\mathrm{OPr}^{i}\right)_{4} \cdot \mathrm{Pr}^{i} \mathrm{OH}, \\
\mathrm{Ce}\left(\mathrm{OPr}^{\mathrm{i}}\right)_{4} \cdot \mathrm{C}_{5} \mathrm{H}_{5} \mathrm{~N}, & \text { and } \mathrm{Sn}\left(\mathrm{OPr}^{i}\right)_{4} \cdot \mathrm{Pr}^{i} \mathrm{OH}(15) .
\end{array}
$$

An explanation by Bradley(15) implies that since these compounds all contain the iso-propyl or iso-butyl group, it may indicate that these molecules are too sterically hindered to polymerize, but still can accept donor molecules(15). Hagikara and Yamazaki found that $\mathrm{Cr}\left(\mathrm{OBu}^{\mathrm{t}}\right)_{4}$ did not polymerize styrene in benzene solution but on addition of methanol polymerization occurred along with the formation of $\mathrm{Cr}(\mathrm{OMe})_{3}, \mathrm{Bu}^{\mathrm{t}} \mathrm{OH}$, and formaldehyde(15). Apparently, methanol produced radicals during the reaction. Wiberg and Foster(19) using 
${ }^{15} 0-1$ abelled water in a medium of $91 \%$ acetic acid and 0.23 $M$ perchloric acids showed that in the hydrolysis of $\mathrm{Cr}\left(\mathrm{OBu}^{\mathrm{t}}\right)_{4}$, the $\mathrm{Cr}-0$ bonds were cleaved. Subsequently, they also observed that $\mathrm{Cr}\left(\mathrm{OBu}^{\mathrm{t}}\right)_{4}$, dissolved in styrene, was stable for a week showing that butoxo radicals were not produced, thus confirming the earlier work of Hagihara and Yamazaki(18). Magnetic susceptibility showed that for all of the $\operatorname{Cr}(O R)_{4}$ compounds measured, the magnetic moments are close to the spin-only value of 2.83 for a $d^{2}$ system(12).

\section{Chemical properties.}

a) Hydrolysis: With the simple exception of alkoxides with extremely bulky ligand groups, all transistion metal alkoxides undergo rapid hydrolysis giving hydrated metal oxides (20):

$\mathrm{I}-9 \quad \mathrm{M}(\mathrm{OR})_{\mathrm{x}}+\mathrm{XH}_{2} \mathrm{O} \rightarrow-\rightarrow \mathrm{M}(\mathrm{OH})_{\mathrm{x}}+\mathrm{X} \mathrm{ROH}$

The hydrolysis reaction involves cleavage of the M-0 bond. In the hydrolysis of $\mathrm{Ti}\left(\mathrm{OCH}_{2} \mathrm{C}\left(\mathrm{CH}_{3}\right)_{3}\right)_{4}$, only neo-pentyl alcohol was formed; if $\mathrm{C}-\mathrm{O}$ bond cleavage occurred, there would have been a rapid Meerwein rearrangement of the intermediate carbonium ion to give t-amy1 a1cohol(15).

b) Alcoholysis: Interchange reaction between alcohol and many alkoxides has been used by Bradley as a preparative method(15):

$\mathrm{I}-10 \mathrm{Cr}(\mathrm{OR})_{\mathrm{x}}+\mathrm{R}^{\prime} \mathrm{OH} \longrightarrow \mathrm{Cr}\left(\mathrm{OR}^{\prime}\right)_{\mathrm{x}}+\mathrm{X} \mathrm{ROH}$ 
Exchange is fast in cases where steric hindrance is not a major factor. However, for bulky ligands (e.g. t-butyl, t-amyl, etc.) the exchange is slow(15). The mechanism of the reaction is not fully understood; Varma and Mehrota(21) gave the following comparative reactivity of alkoxy groups in alcoholysis as: MeO $>E_{t} O>\mathrm{Pr}^{i} \mathrm{O}>\mathrm{Bu}^{\mathrm{t}} \mathrm{O}$.

c) Reaction with Carbonyl Compounds. The products from the reaction of alkoxides and carbonyl compounds were found to depend on the basicity of the alkoxide(15). In a Cannizzaro-like reaction, tha Tischenko reaction converts alkoxides into esters using metal alkoxides such as a 1 uminium ethoxide(15):

I-11 RCHO $\rightarrow \mathrm{RCO}_{2} \mathrm{CH}_{2} \mathrm{R}$.

As is characteristic of Cannizzaro reactions, the reaction probably goes through a hydride transfer. In the we11-known Meerwein-Ponndorf-Verley reaction, aldehydes or ketones are converted to alcohols in the presence of alkoxides(15):

$\mathrm{I}-12 \quad \mathrm{R}_{2} \mathrm{CO}+\mathrm{R}^{\prime} \mathrm{CH}_{2} \mathrm{OH} \rightarrow \mathrm{R}_{2} \mathrm{CHOH}+\mathrm{R}^{\prime} \mathrm{CHO}$

d) Reaction with Anhydrides and Ethers. Metal alkoxides react with anhydrides and esters to give transesterification products(15):

$\mathrm{I}-13 \mathrm{M}(\mathrm{OR})_{\mathrm{x}}+\mathrm{X} \mathrm{RCO}_{2} \mathrm{R}^{\prime} \rightarrow \mathrm{M}(\mathrm{OR})_{\mathrm{x}}+\mathrm{x} \mathrm{RCO}_{2} \mathrm{R}$

Statement of purpose. 
The purpose of the present study was to prepare, characterize and study the chemistry of new chromium(IV) butoxides. Several exchange reactions were performed as well as oxidation of fluorinated alcohols. Chromium(IV) tertiary butoxide was selected as the most convenient compound in the group. A summary of the reactions studied is given in Table $V$. 


\section{TABLE V}

REACTIONS DISCUSSED IN CHAPTER III.

REACTANTS

\section{$\underline{\text { PRODUCTS }}$}

$$
\begin{aligned}
& \mathrm{CrF}_{3}+\mathrm{F}_{2} \\
& -->\quad \mathrm{CrF}_{5} \\
& \mathrm{CrF}_{5}+\frac{1}{2} \mathrm{Cl}_{2} \\
& -->\mathrm{CrF}_{4}+\mathrm{ClF} \\
& \mathrm{CrCl}_{3}+3 \text { LiNEt }_{2} \\
& -\rightarrow \quad \mathrm{Cr}\left(\mathrm{NEt}_{2}\right)_{4}+\mathrm{Cr}\left(\mathrm{NEt}_{2}\right)_{2} \\
& \mathrm{Cr}\left(\mathrm{OC}_{4} \mathrm{H}_{9}\right)_{4}+4 \mathrm{AgCF}_{3} \mathrm{COO} \\
& -->\mathrm{Cr}\left(\mathrm{CF}_{3} \mathrm{COO}\right)_{4}+4 \mathrm{C}_{4} \mathrm{H}_{9} \mathrm{OAg} \text { ? } \\
& \mathrm{Cr}\left(\mathrm{OC}_{4} \mathrm{H}_{9}\right)_{4}+4 \mathrm{HF} \\
& -->\mathrm{CrF}_{4}+4 \mathrm{C}_{4} \mathrm{H}_{9} \mathrm{OH} \text { ? } \\
& \mathrm{Cr}\left(\mathrm{OC}_{4} \mathrm{H}_{9}\right)_{4}+4 \mathrm{CF}_{3} \mathrm{CH}_{2} \mathrm{OH} \\
& -->\mathrm{Cr}\left(\mathrm{OCH}_{2} \mathrm{CF}_{3}\right)_{4}+4 \mathrm{C}_{4} \mathrm{H}_{9} \mathrm{OH} \text { ? } \\
& \mathrm{Cr}\left(\mathrm{OC}_{4} \mathrm{H}_{9}\right)_{4}+4\left(\mathrm{CF}_{3}\right)_{2} \mathrm{CHOH}---\mathrm{Cr}\left(\mathrm{OCH}\left(\mathrm{CF}_{3}\right)_{2}\right)_{4} \\
& +4 \mathrm{C}_{4} \mathrm{H}_{9} \mathrm{OH} \text { ? } \\
& \mathrm{Cr}\left(\mathrm{OC}_{4} \mathrm{H}_{9}\right)_{4}+\mathrm{C}_{6} \mathrm{~F}_{5} \mathrm{OH} \\
& -->\quad * \\
& \mathrm{Cr}\left(\mathrm{OC}_{4} \mathrm{H}_{9}\right)_{4}+\left(\mathrm{C}_{6} \mathrm{H}_{5}\right)_{3} \mathrm{SiOH} \quad-\rightarrow \text { * } \\
& \mathrm{Cr}\left(\mathrm{OC}_{4} \mathrm{H}_{9}\right)_{4}+\left(\mathrm{CF}_{3}\right)_{3} \mathrm{COH} \quad-->\text { * } \\
& \mathrm{Cr}\left(\mathrm{NEt}_{2}\right)_{3}+3 \mathrm{CF}_{3} \mathrm{CH}_{2} \mathrm{OH} \quad--\mathrm{Cr}\left(\mathrm{OCH}_{2} \mathrm{CF}_{3}\right)_{3} \text { * } \\
& \mathrm{Cr}\left(\mathrm{NEt}_{2}\right)_{3}+3\left(\mathrm{CF}_{3}\right)_{2} \mathrm{CHOH} \rightarrow-\rightarrow \mathrm{Cr}\left(\mathrm{OCH}\left(\mathrm{CF}_{3}\right)_{2}\right)_{3} \text { * }
\end{aligned}
$$

? the +4 oxidation state of chromium in these products is questionable.

* products not fully characterized. 
B. FLUORINATED HYPOCHLORITES.

For many years, research with organic hypochlorites was limited due to the instability of the hydrocarbon systems. In 1969, perfluorinated alkyl hypochlorites were reported(22). These new compounds, unlike their hydrocarbon analogs, are stable. For example, $\mathrm{CH}_{3} \mathrm{OCl}$ decomposes explosively at room temperature while $\mathrm{CF}_{3} \mathrm{OCl}$ is stable up to $150^{\circ} \mathrm{C}$. The fluorinated hypochlorites have generated much interest and excitement in this field. In addition to the hypochlorite, $\left(\mathrm{CF}_{3}\right)_{3} \operatorname{COCl}(23)$, various fluorinated hypochlorites have been prepared. The list include:

$\mathrm{CF}_{3} \mathrm{OCl}, \mathrm{C}_{2} \mathrm{~F}_{5} \mathrm{OCl} 1, \mathrm{i}-\mathrm{C}_{3} \mathrm{~F}_{7} \mathrm{OCl}, \mathrm{CF}_{2} \mathrm{ClCF}\left(\mathrm{CF}_{3}\right) \mathrm{OCl}, \mathrm{C} 10\left(\mathrm{CF}_{2}\right)_{5} \mathrm{OCl}$, and $\mathrm{SF}_{5} \mathrm{OCl}(22)$.

The preparation of fluorinated hypochlorites seem to follow a regular pattern: the first five in the above list are most conveniently prepared through the cesium fluoride catalyzed addition of chlorine monofluoride to the appropriate carbonyl compound at low temperatures. Pentafluorosulfur hypochlorite is prepared through an analogous reaction in which $\mathrm{F}_{4} \mathrm{SO}$ is used rather than a carbonyl compound(22).

F-(tert-butyl) hypochlorite, $\left(\mathrm{CF}_{3}\right)_{3} \mathrm{COCl}$, was first prepared by the reaction between $\left(\mathrm{CF}_{3}\right)_{3} \mathrm{COH}$ and $\mathrm{ClF}$ at room 
temperature(23). The reaction of sodium hydride with the parent alcohol in diethyl ether to form the sodium salt of F-(tert-butyl) alcohol provided an alternative preparative method. Further reaction of the purified salt with C1F under ambient temperature gave the product in essentially quantitative yield(23).

Previous to the formation of F-(tert-buty 1 ) hypochlorite, only primary and secondary perfluoroalkyl hypochlorites had been synthesized(23). The new perhaloalkyl hypochlorites are easily prepared in high yields, in most cases, through the metal fluoride catalyzed reaction of perhaloalkyl carbonyl compounds with chlorine monofluoride.

The general preparation of hypochlorites involved the addition of C1F across a carbonyl double bond in the presence of a catalyst:

$$
R^{\prime} f \quad R^{\prime} f
$$

$\mathrm{I}-14$

$$
\begin{aligned}
& \mathrm{C}=0+\mathrm{ClF}-\mathrm{F}-\mathrm{C}-\mathrm{OCl} \\
& \mathrm{R}_{\mathrm{f}} \mathrm{R}_{\mathrm{f}}=\mathrm{R}_{\mathrm{f}}^{\prime}=\mathrm{F} \quad \mathrm{R}_{\mathrm{f}} \\
& \mathrm{R}_{\mathrm{f}}=\mathrm{R}_{\mathrm{f}}^{\prime}=\mathrm{CF}_{3} \\
& \mathrm{R}_{\mathrm{f}}=\mathrm{F} ; \mathrm{R}_{\mathrm{f}}^{\prime}=\mathrm{CF}_{3} \\
& \mathrm{R}_{\mathrm{f}}=\mathrm{CF}_{2} \mathrm{Cl} ; \mathrm{R}_{\mathrm{f}}^{\prime}=\mathrm{CF}_{3}
\end{aligned}
$$

The catalyst normally employed was either a metal fluoride, generally CsF, but not $K F$ or $\operatorname{RbF}(22,24)$; a Lewis 
acid $\mathrm{HF}, \mathrm{BF}_{3}, \mathrm{AsF}_{5}$ but not $\mathrm{PF}_{5}(42)$; or the gaseous $\mathrm{FNO}(26)$ have been successfully used. The chlorofluorination technique appears to be quite general and was also used to prepare the difunctional compound, decafluoropentane1,5-dihypoch1orite:

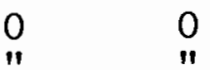

$$
\text { I-15 } \mathrm{FC}\left(\mathrm{CF}_{2}\right)_{2} \mathrm{CF}+2 \mathrm{ClF} \rightarrow-\rightarrow \mathrm{C} 10\left(\mathrm{CF}_{2}\right)_{5} \mathrm{OCl}
$$

as we11 as the inorganic pentafluorosulfur hypochlorite:

I-16

$$
\mathrm{F}_{4} \mathrm{SO}+\mathrm{C} 1 \mathrm{~F}-\rightarrow \mathrm{SF}_{5} \mathrm{OCl} \text { (22). }
$$

The hydrolytic stability of the fluorinated hypochlorites appear to be related to the degree of fluorination in the compound, with the more highly fluorinated compound having a higher degree of susceptibilty towards hydrolysis. Thus $\left(\mathrm{CF}_{3}\right)_{3} \mathrm{COCl}$ was shown to be least hydrolytically stable in the series:

$\left(\mathrm{CF}_{3}\right)_{3} \mathrm{COCl}<\mathrm{CH}_{3} \mathrm{C}\left(\mathrm{CF}_{3}\right)_{3} \mathrm{OC} 1 \approx\left(\mathrm{CF}_{3}\right)_{2} \mathrm{CHOC} 1<\mathrm{CF}_{3} \mathrm{CH}_{2} \mathrm{OCl}$

$$
<\left(\mathrm{CH}_{3}\right)_{3} \mathrm{COC1}(23) \text {. }
$$

The thermal stablity of the hypochlorites is shown by the ease with which they decompose at elevated temperatures. In particular, $\mathrm{CF}_{3} \mathrm{OCl}$ decomposes slowly at $150^{\circ}(22)$. The other hypochlorites are, in general, less stable (or more reactive) than $\mathrm{CF}_{3} \mathrm{OC} 1$ with the order of stability given by the series(22):

$\mathrm{CF}_{3} \mathrm{OCl}>\mathrm{C}_{2} \mathrm{~F}_{5} \mathrm{OCl}=\mathrm{i}-\mathrm{C}_{3} \mathrm{~F}_{7} \mathrm{OCl}>\mathrm{SF}_{5} \mathrm{OCl}$

Hypochlorites have provided a convenient route to the 
preparation of various butoxides. Many of these are listed in Table VI(31). Table VII also lists the reactions of $\mathrm{F}-($ tert-butyl) hypochlorite studied in our laboratory by Dr. G. L. Gard, JoAnn Canich et a1.(27). Polyfluoroalkyl hypochlorites add readily and, in most cases, nearly quantitatively to both unsubstituted and halogen-substituted terminal olefins.

The use of mercurial, $\left(\mathrm{CF}_{3}\right)_{2} \mathrm{COHgCl}$, from the reaction of $\mathrm{F}$-(tert-buty 1 ) hypochlorite with mercury metal in the presence of a solvent(28) has provided yet another useful reagent for the introduction of the F-(tert-butoxy) groups into a number of compounds containing a labile halogen. Table VIII lists several of these reactions(31).

Heptafluoroisopropyl hypochlorite. While a great deal of attention has been given to $\mathrm{CF}_{3} \mathrm{OCl}$ and $\left(\mathrm{CF}_{3}\right)_{3} \mathrm{COCl}$, only a limited number of studies have been carried out with $\left(\mathrm{CF}_{3}\right)_{2} \mathrm{CFOC1}$. The preparation of heptafluoroisopropyl hypochlorite, $i-\mathrm{C}_{3} \mathrm{~F}_{7} \mathrm{OCl}$, follows the usual preparative technique(22). Hexafluoroacetone and a slight excess of C1F were condensed into a CsF vessel at $-20^{\circ}$. Reactions are normally left overnight, although 2 to 3 hours is sufficient for reaction completion. Heptafluoroisopropyl hypochlorite is a clear yellow liquid; the infrared spectrum shows absorptions at $1320(\mathrm{~s}), 1250(\mathrm{~s}), 1215(\mathrm{~m})$, 
TABLE VI

SOME OF THE RNOWN REACTIONS OF F-t-BUTYL HYPOCHLORITE(31)

\section{REACTANTS}

$\left(\mathrm{CF}_{3}\right)_{3} \mathrm{COCl}+\mathrm{SO}_{2}$

$\left(\mathrm{CF}_{3}\right)_{3} \mathrm{COCl}+\mathrm{CO}$

$\left(\mathrm{CF}_{3}\right)_{3} \mathrm{COCl}+\mathrm{CF}_{2}=\mathrm{CF}_{2}$

$\left(\mathrm{CF}_{3}\right)_{3} \mathrm{COCl}+\mathrm{CH}_{2}=\mathrm{CH}_{2}$

$2\left(\mathrm{CF}_{3}\right)_{3} \mathrm{COCl}+\mathrm{CF}_{3} \mathrm{SCl}$

$\left(\mathrm{CF}_{3}\right)_{3} \mathrm{COC} 1+\mathrm{CF}_{3} \mathrm{~S}(\mathrm{O}) \mathrm{Cl}$

$4\left(\mathrm{CF}_{3}\right)_{3} \mathrm{COCl}+\mathrm{SCl}_{2}$

$8\left(\mathrm{CF}_{3}\right)_{3} \mathrm{COCl}+\mathrm{S}_{2} \mathrm{Cl}_{2}$

$\left(\mathrm{CF}_{3}\right)_{3} \mathrm{COCl}+\mathrm{CS}_{2}$

$\left(\mathrm{CF}_{3}\right)_{3} \mathrm{COCl}+\mathrm{PClF}_{4}$

$2\left(\mathrm{CF}_{3}\right)_{3} \mathrm{COCl}+\mathrm{PCl}_{2} \mathrm{~F}_{3}$

$5\left(\mathrm{CF}_{3}\right)_{3} \mathrm{COCl}+\mathrm{PCl}_{5}$

$3\left(\mathrm{CF}_{3}\right)_{3} \mathrm{COCl}+\mathrm{PCl} 3$

$2\left(\mathrm{CF}_{3}\right)_{3} \mathrm{COC} 1+\mathrm{PF}_{3}$

$\left(\mathrm{CF}_{3}\right)_{3} \mathrm{COC} 1+\mathrm{NOCl}$

$4\left(\mathrm{CF}_{3}\right)_{3} \mathrm{COC} 1+\mathrm{S}_{4} \mathrm{~N}_{4}$

$3\left(\mathrm{CF}_{3}\right)_{3} \mathrm{COC} 1+\mathrm{BCl}_{3}$

$2\left(\mathrm{CF}_{3}\right)_{3} \mathrm{COCl}+\mathrm{CrO}_{2} \mathrm{Cl}_{2}$

$4\left(\mathrm{CF}_{3}\right)_{3} \mathrm{COC} 1+\mathrm{TiCl}_{4}$

$\left(\mathrm{CF}_{3}\right)_{3} \mathrm{COCl}+\mathrm{Hg}$
PRODUCTS

$\longrightarrow\left(\mathrm{CF}_{3}\right)_{3} \mathrm{COSO}_{2} \mathrm{Cl}$

$\longrightarrow \quad\left(\mathrm{CF}_{3}\right)_{3} \mathrm{COC}(\mathrm{O}) \mathrm{Cl}$

$\rightarrow\left(\mathrm{CF}_{3}\right)_{3} \mathrm{COCF}_{2} \mathrm{CF}_{2} \mathrm{Cl}$

$\longrightarrow \quad\left(\mathrm{CF}_{3}\right)_{3} \mathrm{COCH}_{2} \mathrm{CH}_{2} \mathrm{Cl}$

$\rightarrow\left[\left(\mathrm{CF}_{3}\right)_{3} \mathrm{CO}\right]_{2} \mathrm{SClCF}_{3}+\mathrm{Cl}_{2}$

$-\rightarrow \mathrm{CF}_{3} \mathrm{~S}(\mathrm{O}) \mathrm{OC}\left(\mathrm{CF}_{3}\right)_{3}+\mathrm{Cl}_{2}$

$\rightarrow \mathrm{S}\left[\mathrm{OC}\left(\mathrm{CF}_{3}\right)_{3}\right]_{4}+3 \mathrm{Cl}_{2}$

$\rightarrow 2 \mathrm{~S}\left[\mathrm{OC}\left(\mathrm{CF}_{3}\right)_{3}\right]_{4}+5 \mathrm{Cl}_{2}$

$\rightarrow \mathrm{S}\left[\mathrm{OC}\left(\mathrm{CF}_{3}\right)_{3}\right]_{4}$

$\rightarrow\left(\mathrm{CF}_{3}\right)_{3} \mathrm{COPF}_{4}+\mathrm{Cl}_{2}$

$\rightarrow\left[\left(\mathrm{CF}_{3}\right)_{3} \mathrm{CO}\right] \mathrm{PF}_{3}+2 \mathrm{Cl}_{2}$

$\rightarrow \mathrm{P}\left[\mathrm{OC}\left(\mathrm{CF}_{3}\right)_{3}\right]_{5}+5 \mathrm{Cl}_{2}$

$\rightarrow P\left[O C\left(\mathrm{CF}_{3}\right)_{3}\right]_{3}+3 \mathrm{Cl}_{2}$

$\rightarrow\left[\left(\mathrm{CF}_{3}\right)_{3} \mathrm{CO}_{2} \mathrm{PF}_{3}+\mathrm{Cl}_{2}\right.$

$\rightarrow\left(\mathrm{CF}_{3}\right)_{3} \mathrm{CONO}+\mathrm{Cl}_{2}$

$\rightarrow \mathrm{N}_{4} \mathrm{~S}_{4}\left[\mathrm{OC}\left(\mathrm{CF}_{3}\right)_{3}\right]_{4}+2 \mathrm{Cl}_{2}$

$\longrightarrow \mathrm{B}\left[\mathrm{OC}\left(\mathrm{CF}_{3}\right)_{3}\right]_{3}+3 \mathrm{Cl}_{2}$

$\longrightarrow \mathrm{CrO}_{2}\left[\mathrm{OC}\left(\mathrm{CF}_{3}\right)_{3}\right]_{2}+2 \mathrm{Cl}_{2}$

$\rightarrow \operatorname{Ti}\left[\mathrm{OC}\left(\mathrm{CF}_{3}\right)_{3}\right]_{4}+4 \mathrm{Cl}_{2}$

$\rightarrow\left(\mathrm{CF}_{3}\right)_{3} \mathrm{COHgCl}$ 
TABLE VII

SOME OF THE REACTIONS OF F-t-BUTYL HYPOCHLORITE STUDIED IN DR. GARD'S LABORATORY AT PORTLAND STATE UNIVERSITY

\section{REACTANTS}

$\left(\mathrm{CF}_{3}\right)_{3} \mathrm{COCl}+\mathrm{VOCl}_{3}$

$\left(\mathrm{CF}_{3}\right)_{3} \mathrm{COCL}+\mathrm{SbCl}_{5}$

$\left(\mathrm{CF}_{3}\right)_{3} \mathrm{COCl}+\mathrm{Cu}_{2} \mathrm{Cl}_{2}$

$\left(\mathrm{CF}_{3}\right)_{3} \mathrm{COCl}+\mathrm{MCl}_{4}$

( $M=S n, S i, T i)$
$\left(\mathrm{CF}_{3}\right)_{3} \mathrm{COCl}+\mathrm{Pb}$

$\left(\mathrm{CF}_{3}\right)_{3} \mathrm{COCl}+\mathrm{Te}$

$\left(\mathrm{CF}_{3}\right)_{3} \mathrm{COCl}+\mathrm{Bi}$

$\left(\mathrm{CF}_{3}\right)_{3} \mathrm{COCl}+\mathrm{Si}$

$\left(\mathrm{CF}_{3}\right)_{3} \mathrm{COCl}+\mathrm{S}_{8}$

$\left(\mathrm{CF}_{3}\right)_{3} \mathrm{COCl}+\mathrm{Br}_{2}$

$\left(\mathrm{CF}_{3}\right)_{3} \mathrm{COCl}+\mathrm{I}_{2}$

$\left(\mathrm{CF}_{3}\right)_{3} \mathrm{COCl}+\mathrm{CF}_{3} \mathrm{I}$

$\left(\mathrm{CF}_{3}\right)_{3} \mathrm{COCl}+\mathrm{ICF}_{2} \mathrm{CF}_{2} \mathrm{I}$

$\left(\mathrm{CF}_{3}\right)_{3} \mathrm{COC} 1+\mathrm{SF}_{5} \mathrm{CF}_{2} \mathrm{CF}_{2} \mathrm{I}$

$\left(\mathrm{CF}_{3}\right)_{3} \mathrm{COCl}+\mathrm{C}_{6} \mathrm{~F}_{5} \mathrm{I}$
PRODUCTS

$\rightarrow \quad \mathrm{VO}\left[\mathrm{OC}\left(\mathrm{CF}_{3}\right)_{3}\right]_{3}$

$\longrightarrow \mathrm{Sb}\left[\mathrm{OC}\left(\mathrm{CF}_{3}\right)_{3}\right]_{x} \mathrm{Cl}_{y}$

--> no reaction occurred

$\rightarrow$ no reaction occurred

$\rightarrow \mathrm{Pb}\left[\mathrm{OC}\left(\mathrm{CF}_{3}\right)_{3}\right]_{2}$

$\rightarrow \operatorname{Te}\left[\mathrm{OC}\left(\mathrm{CF}_{3}\right)_{3}\right]_{4}$

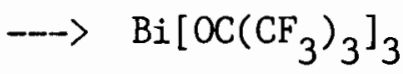

$\rightarrow$ no reaction occurred

$\rightarrow \mathrm{S}\left[\mathrm{OC}\left(\mathrm{CF}_{3}\right)_{3}\right]_{4}$

$\rightarrow\left[\left(\mathrm{CF}_{3}\right)_{3} \mathrm{COBr}\right]$

$\rightarrow\left(\mathrm{CF}_{3}\right)_{2} \mathrm{CO}+\mathrm{CF}_{3} \mathrm{Br}$

$\longrightarrow \mathrm{I}\left[\mathrm{OC}\left(\mathrm{CF}_{3}\right)_{3}\right]_{3}$

$\rightarrow \mathrm{CF}_{3} \mathrm{I}\left[\mathrm{OC}\left(\mathrm{CF}_{3}\right)_{3}\right]_{2}$

$\rightarrow \quad\left[\left(\mathrm{CF}_{3}\right)_{3} \mathrm{CO}_{2} \mathrm{ICF}_{2} \mathrm{CF}_{2} \mathrm{I}\left[\left(\mathrm{CF}_{3}\right)_{3} \mathrm{CO}_{2}\right.\right.$ *

$\rightarrow \mathrm{SF}_{5} \mathrm{CF}_{2} \mathrm{CF}_{2} \mathrm{I}\left[\left(\mathrm{CF}_{3}\right)_{3} \mathrm{CO}_{2}\right.$ *

$\rightarrow \mathrm{C}_{6} \mathrm{~F}_{5} \mathrm{I}\left[\left(\mathrm{CF}_{3}\right)_{3} \mathrm{CO}_{2}\right.$ *

* Dr. G. L. Gard et a1., accepted for publication, Inorg. Chem. 1986. 
TABLE VIII

THE REACTIONS OF $\left(\mathrm{CF}_{3}\right)_{3} \mathrm{COHgCl}(31)$

$$
\begin{aligned}
& \left(\mathrm{CF}_{3}\right)_{3} \mathrm{COHgCl}+\mathrm{CH}_{3} \mathrm{I} \quad \longrightarrow \mathrm{CH}_{3} \mathrm{OC}\left(\mathrm{CF}_{3}\right)_{3} \\
& \left(\mathrm{CF}_{3}\right)_{3} \mathrm{COHgCl}+\mathrm{CF}_{3} \mathrm{SCl} \quad-->\mathrm{CF}_{3} \mathrm{SOC}\left(\mathrm{CF}_{3}\right)_{3} \\
& \left(\mathrm{CF}_{3}\right)_{3} \mathrm{COHgCl}+\mathrm{CF}_{3} \mathrm{C}(\mathrm{O}) \mathrm{Br} \quad \cdots \mathrm{CF}_{3} \mathrm{C}(0) \mathrm{OC}\left(\mathrm{CF}_{3}\right)_{3} \\
& \left(\mathrm{CF}_{3}\right)_{3} \mathrm{COHgCl}+\mathrm{CF}_{3} \mathrm{C}(\mathrm{O}) \mathrm{SCl}-\cdots \mathrm{CF}_{3} \mathrm{C}(0) \mathrm{SOC}\left(\mathrm{CF}_{3}\right)_{3} \\
& \left(\mathrm{CF}_{3}\right)_{3} \mathrm{COHgCl}+\left(\mathrm{CH}_{3}\right)_{3} \mathrm{SiCl}-\cdots\left(\mathrm{CH}_{3}\right)_{3} \mathrm{SiOC}\left(\mathrm{CF}_{3}\right)_{3}
\end{aligned}
$$

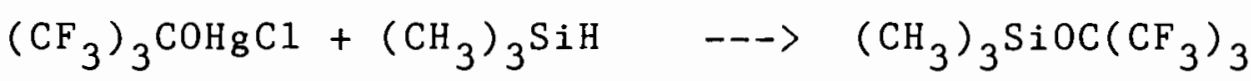

$$
\begin{aligned}
& +\left(\mathrm{CF}_{3}\right)_{3} \mathrm{COH} \\
& \left(\mathrm{CF}_{3}\right)_{3} \mathrm{COHgCl}+\mathrm{CH}_{3} \mathrm{C}(\mathrm{O}) \mathrm{Cl} \quad--\mathrm{CH}_{3} \mathrm{C}(0) \mathrm{OC}\left(\mathrm{CF}_{3}\right)_{3} \\
& \left(\mathrm{CF}_{3}\right)_{3} \mathrm{COHgCl}+\mathrm{CNCl} \quad--\rightarrow\left(\mathrm{CF}_{3}\right)_{3} \mathrm{COCN}
\end{aligned}
$$


$1190(\mathrm{~m}), 1155(\mathrm{~s}), 1005(\mathrm{~s}), \quad 795(\mathrm{w}), \quad 755(\mathrm{~m}), \quad 728(\mathrm{~m}), \quad$ and $665(w)$; these include the characteristic absorptions of C-F and $0-C 1$ bonds(22). The ${ }^{19} \mathrm{~F}$ NMR spectrum contains unresolved peaks at +81.3 and +143 , relative to a $\mathrm{CCl}_{3} \mathrm{~F}$ internal standard(22).

Due to the hydrolytic instability of these hypochlorites in general, melting point and boiling point of the heptafluoroisopropyl hypochlorite have not been determined. However, Gould et al.(22) have calculated a boiling point of $22^{\circ}$ for the hypochlorite and a latent heat of vaporization of $6378 \mathrm{cal}^{\mathrm{mol}}{ }^{-1}$.

Heptafluoroisopropyl hypochlorite is fairly stable at room temperature. However, at higher temperatures it decomposes to $\mathrm{CF}_{3} \mathrm{C}(0) \mathrm{F}, \mathrm{CF}_{3} \mathrm{Cl},\left(\mathrm{CF}_{3}\right)_{2} \mathrm{C}=0$ and $\mathrm{C} 1 \mathrm{~F}$ according to the following mechanistic scheme(22):

$$
\begin{aligned}
& \mathrm{CF}_{3} \quad \mathrm{CF}_{3} \\
& \mathrm{I}-17 \mathrm{~F}-\mathrm{C}-\mathrm{O}-\mathrm{Cl} \rightarrow-\mathrm{F}-\mathrm{C}-\mathrm{O}^{\circ}+\mathrm{Cl} \\
& \mathrm{CF}_{3} \quad \mathrm{CF}_{3} \\
& \mathrm{CF}_{3} \quad \mathrm{CF}_{3} \\
& \mathrm{I}-18 \mathrm{~F}-\mathrm{C}-\mathrm{O}^{\circ} \rightarrow \rightarrow \mathrm{C}=0+\mathrm{F}^{\cdot} \\
& \mathrm{CF}_{3} \quad \mathrm{CF}_{3} \\
& \mathrm{CF}_{3} \\
& \text { I-19 } \mathrm{F}-\mathrm{C}-\mathrm{O}^{\cdot} \rightarrow \mathrm{F}-\mathrm{C}=0+\mathrm{CF}_{3} \\
& \mathrm{CF}_{3} \quad \mathrm{CF}_{3}
\end{aligned}
$$


$\mathrm{I}-20 \cdot \mathrm{CF}_{3}+\mathrm{Cl} \cdot--\rightarrow \mathrm{CF}_{3} \mathrm{Cl}$

$\mathrm{I}-21 \quad \mathrm{C} 1^{\bullet}+\mathrm{F}^{\cdot}--->\mathrm{ClF}$

However, with heptafluoroisopropyl hypochlorite, its reaction with olefins has been reported for only one system; $\quad\left(\mathrm{CF}_{3}\right)_{2} \mathrm{CFOC1}$ adds to TFE quantitatively to yield the corresponding ether according to the equation:(29)

$\mathrm{I}-22 \quad \mathrm{i}-\mathrm{C}_{3} \mathrm{~F}_{7} \mathrm{OCl}+\mathrm{F}_{2} \mathrm{C}=\mathrm{CF}_{2}--\rightarrow \mathrm{i}-\mathrm{C}_{3} \mathrm{~F}_{7} \mathrm{OCF}_{2} \mathrm{CF}_{2} \mathrm{Cl}$

PERFLUORO-tert-AMYL HYPOCHLORITE:

As the chemistry of fluorine and its organic compounds progresses in Dr. Gard's laboratory, it becomes increasingly evident that a vast new field of study is being opened up. The knowledge that one trifluoromethyl group in the alpha position of an alcohol is all that is necessary to allow preparation of the corresponding hypochlorite by reaction with chlorine monofluoride and the experimental evidence provided by the use of other known hypochlorites, prompted this inquisition into the preparation of the new perfluoro-t-amyl hypochlorite from the parent perfluoro-t-amyl alcohol.

This study thus reports the first preparation of the perfluoro-t-amyl hypochlorite, $\quad \mathrm{CF}_{3} \mathrm{CF}_{2} \mathrm{C}\left(\mathrm{CF}_{3}\right)_{2} \mathrm{OCl}$. Its preparation followed an adaptation of the method used by Gould, Anderson, Young and Fox to prepare other 
hypochlorites(22). The parent alcohol, perfluoro-t-amyl alcohol, $\mathrm{CF}_{3} \mathrm{CF}_{2} \mathrm{C}\left(\mathrm{CF}_{3}\right)_{2} \mathrm{OH}$, prepared through the method used by Graham and Weinmayr(30), and chlorine monofluoride were condensed into a reaction vessel and maintained at low temperatures for several hours. Subsequent transfer to a CsF metal reaction vessel and fractionation at $-78^{\circ} \mathrm{C}$ gave the hypochlorite in quantitative yield.

The fluoro-t-amyl hypochlorite represents yet another significant extension of the new class of compounds, known as fluoroalkyl hypochlorites. A11 previous fluorine-substituted hypochlorites $\left(\mathrm{R}_{\mathrm{f}} \mathrm{OC1}\right) \quad$ are structurally related to known fluoxy compounds $\left(R_{f} O F\right)$, although the two types of materials differ significantly in their chemical behavior(23). Interestingly, treatment of fluoro alcohols containing carbon-hydrogen bonds with such a powerful oxidizing agent as chlorine monofluoride did not produce extensive degradation(40).

While no information is available on the use of $\mathrm{CF}_{3} \mathrm{CF}_{2} \mathrm{C}\left(\mathrm{CF}_{3}\right)_{2} \mathrm{OH}$ in the hypochlorite synthesis, in the series; $\mathrm{CH}_{3} \mathrm{OH}, \quad \mathrm{CF}_{3} \mathrm{CH}_{2} \mathrm{OH}, \quad\left(\mathrm{CF}_{3}\right)_{2} \mathrm{CHOH}, \quad\left(\mathrm{CF}_{3}\right)_{3} \mathrm{COH}$, where hydrogen atoms are progressively replaced by trifluoromethyl groups, the last three members react readily and non-violently with C1F to produce excellent yields of the corresponding hypochlorite(23). The hypochlorite will probably provide routes for synthesizing 
other fluorinated systems with the parent fluoro-amyl group. The reactions studied are summarized in Table IX. Applications of F-(tert-butoxides) have included use as textile-treating agents, monomers, plasticizers, solvents and surfactants(31). Being volatile, the metal F-(tert-butoxides) have potential uses as metal vapor sources and gas transport reagents.

Following the work done on F-(tert-butyl) hypochlorite in preparation of new F-(tert-butoxides) by G. L. Gard and JoAnn Canich et a1.(27,31) in our laboratory, the purpose of this study was to

i) study the chemistry of heptafluoroisopropyl hypochlorite via its reaction with metals, non-metals and olefinic systems.

ii) prepare and study the chemistry of a new hypochlorite, perfluoro-t-amyl hypochlorite.

PERFLUORO-E-

Several perfluoro alkyl carbinols- $\mathrm{C}_{6} \mathrm{~F}_{5} \mathrm{OH}$, $\left[\mathrm{CF}_{3}\left(\mathrm{CF}_{2}\right)_{n}\right]_{2} \mathrm{CHOH}$ and $\left(\mathrm{CF}_{3}\right)_{3} \mathrm{COH}$ (not including the one described here), have been prepared through the interaction of the perfluoro alkyl Grignard reagents with suitable reagents such as fluoroester, (e.g. CF ${ }_{3}$ COOEt), perfluoroketones (e.g. $\mathrm{CF}_{3} \mathrm{COCF}_{3}$ ), perfluoroaldehydes (e.g. $\left.\mathrm{CF}_{3} \mathrm{CHO}\right)(32,33,34)$. 
TABLE IX

REACTIONS DISCUSSED IN CHAPTER IV

$\underline{\text { Reactants }}$
$\left(\mathrm{CF}_{3}\right)_{2} \mathrm{CFOCl}+\mathrm{I}_{2}$
$\left(\mathrm{CF}_{3}\right)_{2} \mathrm{CFOCl}+\mathrm{Hg}$
$\left(\mathrm{CF}_{3}\right)_{2} \mathrm{CFOC1}+\mathrm{TiCl}_{4}$
$\left(\mathrm{CF}_{3}\right)_{2} \mathrm{CFOCl}+\mathrm{SF}_{5} \mathrm{CH}=\mathrm{CH}_{2}$
$\left(\mathrm{CF}_{3}\right)_{2} \mathrm{CFOCl}+\mathrm{SF}_{5} \mathrm{CH}=\mathrm{CF}_{2}$
$\left(\mathrm{CF}_{3}\right)_{2} \mathrm{CFOCl}+\mathrm{CH}_{2}=\mathrm{CH}_{2}$
$\mathrm{CF}_{3} \mathrm{CF}_{2} \mathrm{C}\left(\mathrm{CF}_{3}\right)_{2} \mathrm{OH}+\mathrm{C} 1 \mathrm{~F}$

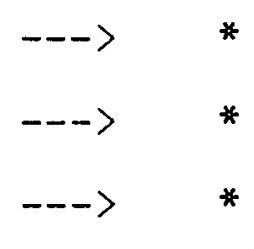
$-->\quad\left(\mathrm{CF}_{3}\right)_{2} \mathrm{CFOCHSF}_{5} \mathrm{CH}_{2} \mathrm{Cl}$
$-->\quad\left(\mathrm{CF}_{3}\right)_{2} \mathrm{CFOCHSF}_{5} \mathrm{CF}_{2} \mathrm{Cl}$
$-->\quad\left(\mathrm{CF}_{3}\right)_{2} \mathrm{CFOCH}_{2} \mathrm{CH}_{2} \mathrm{Cl}$
$---\quad \mathrm{CF}_{3} \mathrm{CF}_{2} \mathrm{C}\left(\mathrm{CF}_{3}\right)_{2} \mathrm{OC} 1$

Product

* Products not fully characterized 
Perfluoro-t-pentyl alcohol, $\quad \mathrm{CF}_{3} \mathrm{CF}_{2} \mathrm{C}\left(\mathrm{CF}_{3}\right)_{2} \mathrm{OH}$, was first made by Graham and Weinmayr(30) 1965, through the TFE interaction with hexafluoroacetone on a CsF catalyst surface.

The mechanism of the reaction is believed to involve the anion: $\mathrm{CF}_{3} \mathrm{CF}_{2}{ }^{-}$formed by the interaction of $\mathrm{TFE}$ and $\operatorname{CsF}(30):$

$\mathrm{I}-23 \mathrm{CsF}+\mathrm{CF}_{2}=\mathrm{CF}_{2}-\rightarrow \mathrm{CF}_{3} \mathrm{CF}_{2}{ }^{-} \mathrm{Cs}^{+}$

Subsequent attack of the anion on the equilibrium concentration of the ketone gives the perfluoro-t-amyl anion which upon acidification releases the alcohol in high yield. Graham and Weinmayr(30) have established the structure of $\mathrm{CF}_{3} \mathrm{CF}_{2} \mathrm{C}\left(\mathrm{CF}_{3}\right)_{2} \mathrm{OH}$ by means of $\mathrm{F}^{19}$ resonance spectrum with three peaks at $+4.08,+42.73$ and $-3.37 \mathrm{ppm}$ and relative areas of 3,2 , and 6 respectively(30).

Other catalyst systems have also been used; NaF and LiF with diglyme produced small yields of the product but required higher temperatures and pressures(30). The use of acetonitrile and benzonitrile with KF, characterized by the near absence of side-reaction TFE polymerization, produced small to moderate yields(30). 


\section{CHAPTER II}

\section{EXPERIMENTAL METHODS}

\section{Apparatus}

Vacuum systems. A glass vacuum system was used for most operations requiring the use of a high vacuum or inert atmosphere conditions. The vacuum system consisted of a manifold constructed from $20 \mathrm{~mm}$ 0.D. Pyrex glass tubing and fitted with four Eck and Krebs $2 \mathrm{~mm}$ high vacuum stopcocks to which Pyrex 10/30 \$ ground glass outer joints were attached. The manifold was evacuated through a liquid nitrogen $\left(-196^{\circ} \mathrm{C}\right)$ cooled trap by a Welch Duo-seal rotary pump. The vacuum was monitored by a Televac thermocouple gauge, and was generally maintained between $10^{-3}$ to $10^{-2}$ torr. Higher pressures within the manifold could be measured when desired, by a two legged mercury manometer to \pm 0.1 torr. All joints in the vacuum system were lubricated with Apiezon-M grease. Figure 1 depicts the basic features of the vacuum system.

For the manipulation of gaseous materials capable of attacking the Pyrex glass, a metal vacuum line was used. An example is the fluorine line. Elemental fluorine was 


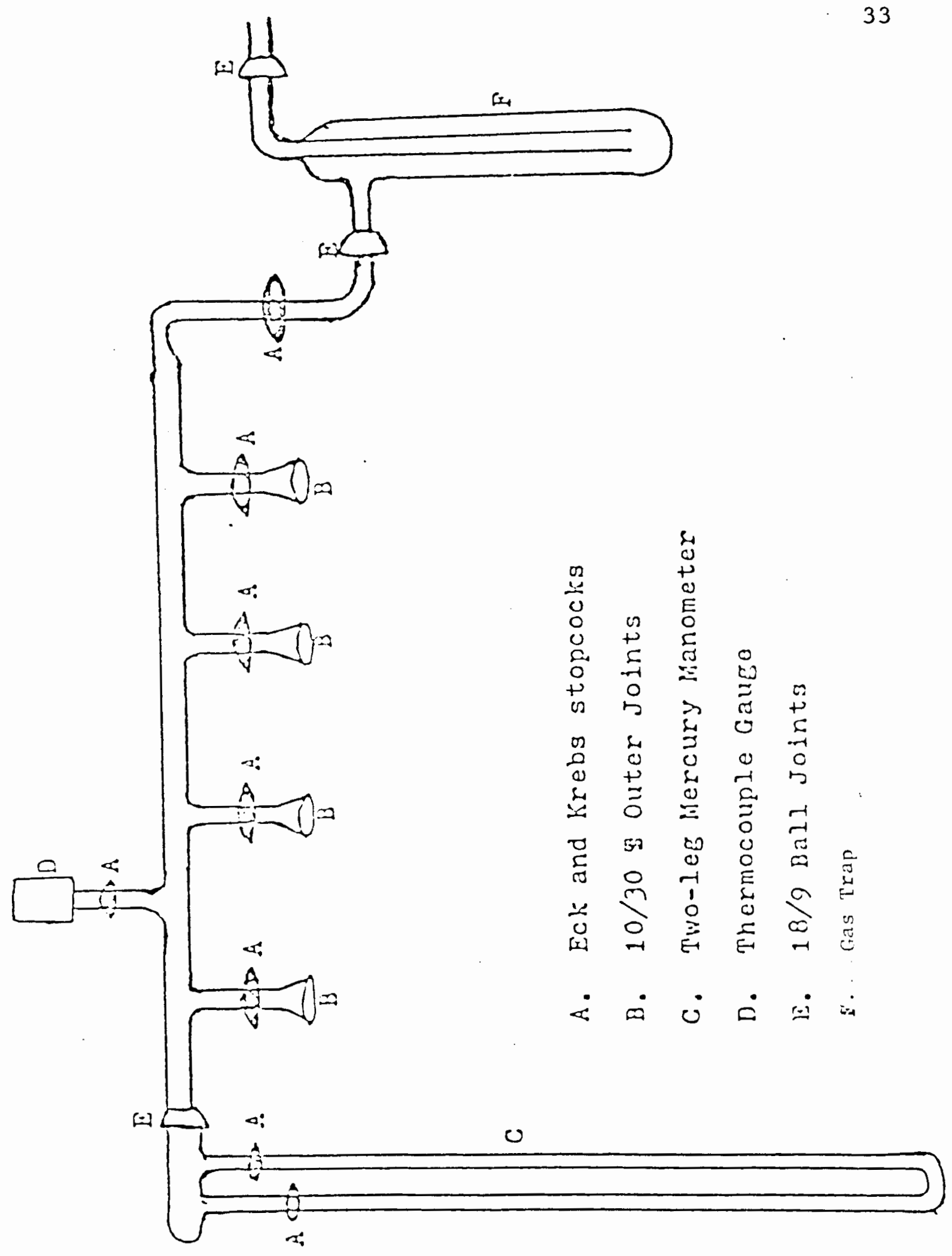

irured, slass vacuum manifold 
transferred in a manifold constructed from a $\frac{1}{4}$ in. 0.0 . copper tubing, to which one VWR valve and one Whitey brass valve terminated in an outer $10 / 30 \$$ brass joint and the outer terminated in $\frac{1}{4}$ in. copper tubing and was used as a venting outlet. Between the fluorine tank and the manifold was fitted a $\frac{1}{2}$ in. O.D. copper U-tube cooled to $-100^{\circ} \mathrm{C}$. which is used to remove $\mathrm{HF}$ impurity. The fluorine was connected directly to the line by Swagelok fittings, and an ACCO diaphram type vacuum pressure gauge was employed to measure pressures up to $30 \mathrm{psi}$. The fluorine line was set up in the laboratory hood. Figure 2 is a diagram of this line.

Reaction vessels.

Reaction vessels used in this study could be divided broadly into two types: low pressure systems and high pressure ones. For most low pressure reactions performed, a $75 \mathrm{~m} 1$ or $100 \mathrm{~m} 1$ Pyrex glass reaction vessel equipped with a Kontes high vacuum Teflon valve and Teflon stirring bar, and tipped with a Pyrex 10/30 \$ inner joint for attachment to the vacuum 1 ine was used. High pressure reactions were performed in a $75 \mathrm{~m} 1$ to $100 \mathrm{ml}$ Hoke Monel vessel equipped with a Whitey stainless steel valve, and tipped with a metal $10 / 30 \$$ inner joint. Reactions which were not compatible with either glass or stainless steel, were carried out in a $35 \mathrm{ml}$ Kel-F reaction vessel fitted with a 

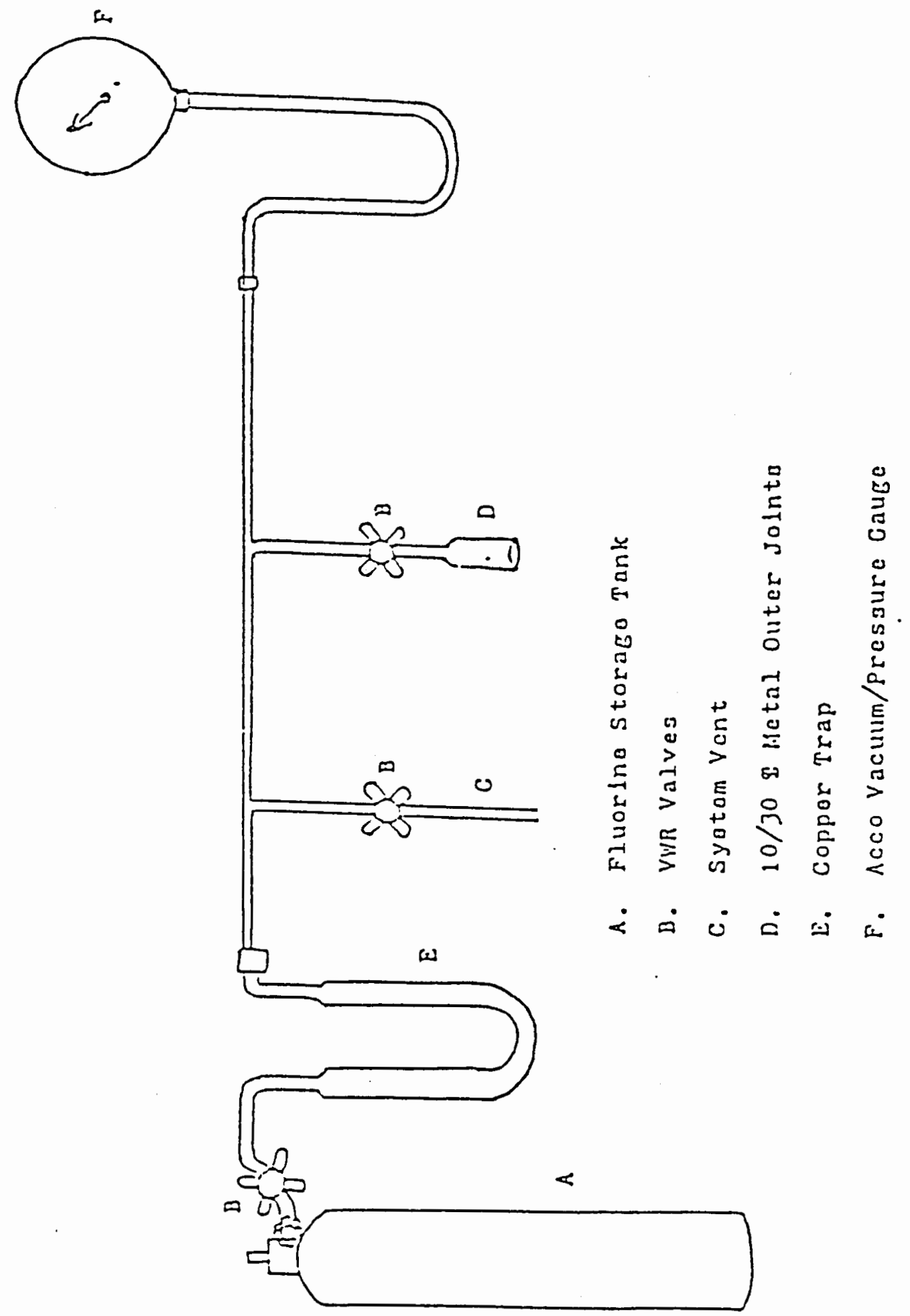

Figure 2. Fluorine Vacuun Line 
Whitey brass valve and a brass $10 / 30$ inner joint.

Vacuum traps. These were constructed of two concentric Pyrex glass tubes of $10 \mathrm{~mm}$ and $20 \mathrm{~mm}$ I.D. A piece of a $10 \mathrm{~mm}$ I.D. Pyrex glass tubing connected the outer tube to a Kontes high vacuum Teflon valve. The inner tube, used to trap substances that would otherwise attack glass, was connected to another Kontes high vacuum Teflon valve. Both valves were fitted with $10 / 30$ \$inner joints for attachment to the vacuum line or other vessels.

Dry Box. All air sensitive compounds were handled under an atmosphere of nitrogen in a Kewaunee Scientific Equipment dry box. Nitrogen was passed into the box through a $\mathrm{CaSO}_{4}$ tube and inside the box was a constant exposure of a large surface area of phosphorus pentoxide used as a drying agent; air circulation inside the box provided a proper contact between the nitrogen atmosphere and the surface of the $\mathrm{P}_{4} \mathrm{O}_{10}$; this was achieved by the use of an electric circulating fan placed inside the dry box.

Glove bag. A plastic glove bag made of polyethylene provided a quick alternative to the dry box. This was usually flushed with liquid nitrogen and regularly maintained under an atmosphere of nitrogen whenever in use. 
Physical methods.

Infrared spectra. The infrared spectra over the range of $4600 \mathrm{~cm}^{-1}$ to $400 \mathrm{~cm}^{-1}$ were recorded on a FT-IR, Nicolet 20DX spectrophotometer equipped with Disk module, Data processor unit and a 7470A Hewlett-Packard plotter. Gaseous samples were run in a glass gas cell fitted with brass $10 / 30$ inner joint for attachment to the vacuum line. The cell windows were $\mathrm{NaCl}, \mathrm{KBr}$, or $\mathrm{KRS}-5$ and the path length of the cell is $8.25 \mathrm{~cm}$. The spectra of non-volatile liquids were obtained neat between $\mathrm{NaCl}$ or $\mathrm{KBr}$ windows. Spectra calibration was achieved with internal polystyrene film.

Nuclear Magnetic Resonance Spectra. Nuclear magnetic resonance spectra were recorded with a Varian Mode1 EM-390 spectrometer operating at $90 \mathrm{MHz}$ for proton and $84.67 \mathrm{MHz}$ for fluorine resonances.

Chemical shifts were reported relative to TMS for proton spectra, and Freon-11 for fluorine spectra with downfield resonances reported as positive values.

Gas Chromatography. Gas chromatographs were obtained with the use of a Varian 3700 Gas Capillary chromatograph. The instrument contained a strip chart recorder, a Varian CDS II Chromatography Data System capable of automatically integrating the sample peaks and retention 
times. The capillary column used was a 30 meter SE-54 with an $0 . D$. of $0.8 \mathrm{~mm}$; a split ratio of 90 to 1 was needed for a typical sample injection of 0.6 microliters. Column temperatures were appropriately adjusted to give the best possible separation within a 15 minute run time.

\section{Reagents.}

Benzene. Spectral grade benzene was purchased from Mallinckrodt, washed and distilled.

Cesium fluoride. CsF was purchased from Specialty Chemicals and was dried under vacuum before use.

Chlorine. $\mathrm{Cl}_{2}$ was purchased from Matheson, Coleman and Bell Company, and was used without further purification.

Chlorine monofluoride. C1F was purchased from Ozark Mahoning Company and used without further purification.

Chromium(III) chloride. $\mathrm{CrCl}_{3}$ was obtained from Alfa Products and used without further purification.

Chromium(III) diethylamine. $\mathrm{Cr}\left(\mathrm{NEt}_{2}\right)_{3}$ was prepared in Dr. G. L. Gard's laboratory by Dr. R. Sheets.

Chromium pentafluoride. $\mathrm{CrF}_{5}$ was prepared in the laboratory through the fluorination of chromium trifluoride at $270-303^{\circ} \mathrm{C}$ for 29 hours.

Chromium tetradiethylamide. $\quad \operatorname{Cr}\left(\mathrm{NEt}_{2}\right)_{4}$ was synthesized by an adaptation of the method used by Bradley 
et a1.(17). $\mathrm{CrCl}_{3}$ in THF was added to a cold LiNEt 2 in diethyl ether and stirred for 8 hours at room temperature. Subsequent filtration and disproportionation gave the tetradiethylamide in quantitative yield.

Chromium tetrafluoride. $\mathrm{CrF}_{4}$ was prepared in the laboratory through the chlorination of $\mathrm{CrF}_{5}$ at $183^{\circ} \mathrm{C}$ for 22 hours.

Chromium tetra-tertiary butoxide. $\mathrm{Cr}\left(\mathrm{OBu}^{\mathrm{t}}\right)_{4}$ was synthesized by the alcoholysis of the chromium tetradiethylamide, a method originally used by Bradley et a1.(17) .

Chromium trifluoride. $\mathrm{CrF}_{3}, \quad(98 \%$ purity), was purchased from Research Organic/Inorganic Chemical Company and was used without further purification.

Dibenzene chromium. $\quad\left(\mathrm{C}_{6} \mathrm{H}_{6}\right)_{2} \mathrm{Cr}$ was purchased from Alfa Products and used without further purification.

Di-tertiary-butyl peroxide. ( $98 \%$ purity) was obtained from PFALTZ and Bauer, Inc., and was used without further purification.

Ethylene. $\mathrm{CH}_{2}=\mathrm{CH}_{2}$ was purchased from Airco Inc., Rare and Specialty Gas Dept., and was used without further purification.

F1uorine. $\quad F_{2}$ (98\% purity), was purchased from Air Products. The fluorine was transferred directly from the tank, through a copper U-tube containing nickel helices 
and cooled to $-100^{\circ} \mathrm{C}$ to remove HF. All manipulations involving the use of fluorine were carried out on a metal line as described under "Physical Methods" section.

Heptafluoroisopropy 1 hypochlorite. i- $\mathrm{C}_{3} \mathrm{~F}_{7} \mathrm{OCl}$ was synthesized by an adaptation of the method used by Gould, Anderson, Young and Fox(22). $\left(\mathrm{CF}_{3}\right)_{2} \mathrm{C}=0$ was condensed into a reaction vessel containing CsF catalyst and excess C1F was immediately added. The vessel was allowed to warm to $-20^{\circ} \mathrm{C}$ and remain there for 8 hours. Fractionation between $-95^{\circ} \mathrm{C}$ and $-196^{\circ} \mathrm{C}$ gave the product $\left(-95^{\circ} \mathrm{C}\right)$ in quantitative yie1d.

Heptafluorosulfur ethylene. $\quad \mathrm{SF}_{5} \mathrm{CH}=\mathrm{CF}_{2}$ was prepared in Dr. Gard's laboratory by R. J. Terjeson.

Hexafluoroacetone. $\quad\left(\mathrm{CF}_{3}\right)_{2} \mathrm{C}=0$ was purchased from DuPont and Co.,Freon Products Division, and was used as received.

Hexafluoropropanol. $\mathrm{CF}_{3} \mathrm{CHOHCF}_{3}$ was purchased from Eastman Chemicals and was used without further purification.

Hydrogen fluoride. HF was purchased from Matheson Company and was used without further purification. A1 1 manipulations involving the use of $\mathrm{HF}$ as a solvent were carried out in a Kel-F vessel.

Iodine. $\mathrm{I}_{2}$ was purchased from Mallinckrodt and was ground into finer particles for a larger surface area 
prior to use.

Lithium diethylamine. LiNEt 2 was purchased from Alfa Products and was used without further purification. Great care was used in handling this chemical due to its high flammability.

Mercury. Analytical reagent grade mercury was purchased from American Scientific and Chemical Company, Amachem, and was used without further purification.

Pentafluorophenol. $\quad \mathrm{C}_{6} \mathrm{~F}_{6} \mathrm{OH}$ was obtained from PCR/SCM and was used without further purification.

Pentafluorosulfur ethylene. $\quad \mathrm{SF}_{5} \mathrm{CH}=\mathrm{CH}_{2}$ was prepared in Dr. G. L. Gard's laboratory by R. J. Terjeson.

Perfluoro-t-pentyl alcohol. $\quad \mathrm{CF}_{3} \mathrm{CF}_{2} \mathrm{C}\left(\mathrm{CF}_{3}\right)_{2} \mathrm{OH}$ was synthesized by an adaptation of the method used by Graham and Weinmayr(30). Cesium fluoride was slurried in diglyme in a pressure vessel. $\left(\mathrm{CF}_{3}\right)_{2} \mathrm{C}=0$ was condensed at roon temperature into the reaction vessel and TFE was subsequent 1 y added at $95-100^{\circ} \mathrm{C}$ (with terpene inhibitor) over a 50 hour period. Filtration and acidification gave the alcohol in good yields.

Perfluoro-t-penty1 hypoch1orite. $\quad \mathrm{CF}_{3} \mathrm{CF}_{2} \mathrm{C}\left(\mathrm{CF}_{3}\right)_{2} \mathrm{OCl}$ was synthesized through the reaction of $\mathrm{CF}_{3} \mathrm{CF}_{2} \mathrm{C}\left(\mathrm{CF}_{3}\right)_{2} \mathrm{OH}$ and C1F on a CsF catalyst surface, following the method used by Young, Anderson, Gould and Fox(22) to prepare other

hypochlorites.

The

parent

alcohol, 
perfluoro-tert-pentyl alcohol, prepared by the adaptation of the method used by Graham and Weinmayr(30) and a slight excess of CIF were condensed into a passivated stainless steel reaction vessel and 1 eft at $-20^{\circ} \mathrm{C}$ for 17 hours. The contents of the vessel were then condensed into a second metal reaction vessel containing a dried excess of CsF catalyst. The vessel was shaken frequently while slowly warming to $0^{\circ} \mathrm{C}$. Fractionation method was employed to separate the $\mathrm{CF}_{3} \mathrm{CF}_{2} \mathrm{C}\left(\mathrm{CF}_{3}\right)_{2} \mathrm{OCl}\left(-78^{\circ}\right)$ from excess $\mathrm{ClF}$ $\left(-196^{\circ}\right)$ and $\mathrm{HF}^{\circ} \mathrm{CsF}$ complex.

tert-Butanol. was purchased from EM Science Company and used without further purification.

Tetrafluoro ethylene. TFE was purchased from PCR/SCM and was used without further purification.

Titanium tetrachloride. $\mathrm{TiCl}_{4}(99.5 \%)$ was purchased from $M C B$ and used without further purification.

Trifluoroethanol. $\mathrm{CF}_{3} \mathrm{CH}_{2} \mathrm{OH}$ was purchased from Specialty Chemicals and was used without further purification.

Triphenyl Silanol. $\quad\left(\mathrm{C}_{6} \mathrm{H}_{5}\right)_{3} \mathrm{SiOH}$ was obtained from PCR/SCM and was used without further purification.

\section{Solvents.}

The following solvents were used in the course of 
this study: Benzene, Tetrahydrofuran (THF), Petroleum ether, Diethyl ether, Pentane, Carbon tetrachloride $\left(\mathrm{CCl}_{4}\right)$, Freon-11, Dichloromethane, Diethylene glycol dimethyl ether (diglyme). Each was dried and refluxed from appropriate drying agent prior to use. 
CHAPTER III

\section{SYNTHESIS OF $\operatorname{Cr}$ (IV) COMPOUNDS}

\section{INTRODUCTION.}

Chromium tetrafluoride.

The preparation of $\mathrm{CrF}_{4}$ reported by Von Wartenberg in 1941 was repeated in the study. Von Wartenberg prepared the tetrafluoride by passing $F_{2}$ over chromium metal, chromium(III) chloride or fluoride at $300^{\circ}-350^{\circ} \mathrm{C}$. In a collaborative study with $\mathrm{Dr}$. Hedberg at the Oregon State University, $\mathrm{CrF}_{4}$ was prepared and purified by reacting $\mathrm{CrF}_{5}$ with $\mathrm{Cl}_{2}$ and subliming the $\mathrm{CrF}_{4}$ solid. This method was preferred in part due to its ease in preparing smal1 quantities of $\mathrm{CrF}_{4}$.

Chromium tetradiethylamide.

$\mathrm{Cr}\left(\mathrm{NEt}_{2}\right)_{4}$ prepared through an adaptation of the method used by Basi et al. provided a good route to the synthesis of the chromium(IV) butoxide. $\operatorname{Cr}\left(\mathrm{NEt}_{2}\right)_{4}$ synthesis was enhanced by the fact that it is highly volatile, thereby easily removed from the chromium(II) dialkylamide during the disproportionation step: 
III-1 $2 \mathrm{Cr}\left(\mathrm{NEt}_{2}\right)_{3} \rightarrow-\rightarrow \quad \mathrm{Cr}\left(\mathrm{NEt}_{2}\right)_{2}+\mathrm{Cr}\left(\mathrm{NEt}_{2}\right)_{4}$ Alcoholysis of the $\mathrm{Cr}\left(\mathrm{NEt}_{2}\right)_{4}$ gives the tetra(a1koxide) in good yield:

$\left.\mathrm{III}-2 \mathrm{Cr}\left(\mathrm{NEt}_{2}\right)_{4}+4 \mathrm{Bu}^{\mathrm{t}} \mathrm{OH} \rightarrow-\mathrm{Cr}_{(\mathrm{OBu}}{ }^{\mathrm{t}}\right)_{4}+4 \mathrm{Et}_{2} \mathrm{NH}$

Synthesis of $\underline{\mathrm{Cr}}(\underline{I V})$ compounds: $\underline{\text { Reactions }}$ of Chromium (IV)-t - -butoxide.

Reactions carried out with $\mathrm{Cr}\left(\mathrm{OC}_{4} \mathrm{H}_{9}\right)_{4}$ are twofold: exchange reactions and oxidation reactions. It was the purpose of this study to prepare and characterize new and interesting $\mathrm{Cr}(\mathrm{IV})$ alkoxides using $\mathrm{Cr}\left(\mathrm{OC}_{4} \mathrm{H}_{9}\right)_{4}$ in exchange reactions with alcohols and metal salts.

In previous studies with primary and secondary alcohols, $\mathrm{Cr}\left(\mathrm{OC}_{4} \mathrm{H}_{9}\right)_{4}$ was found to yield essentially Cr(III) alkoxides and oxidation products. Thus the rate of exchange was slow, and in these cases much slower than oxidation. Table X lists the results of alcoholysis with $1^{\circ}$ and $2^{\circ}$ alcohols $(12)$.

Chromium(IV) has been of interest for some time because of its role as an intermediate in chromic acid oxidation reactions. From the work of Rocek and Radkowsky(35) and a number of investigators $(15,36,37,38)$, the role of chromium(IV) in the chromic acid oxidation of alcohols has been elucidated. The work of these investigators has led to the following mechanism(15): 
TABLE X

RESULTS OF THE REACTION OF $\mathrm{Cr}\left(\mathrm{OC}_{4} \mathrm{H}_{9}\right)_{4}$ WITH PRIMARY AND SECONDARY ALCOHOLS

\begin{tabular}{|c|c|c|c|c|c|}
\hline & Alkoxide & Drying & \multicolumn{2}{|c|}{$\operatorname{Cr}(\%)$} & Oxidation \\
\hline Alcohol & Produced & $\underline{T e m p} \cdot{ }^{\circ} \underline{C}$ & Found & Calc. & Product \\
\hline $\mathrm{MeOH}$ & $\mathrm{Cr}(\mathrm{OMe})_{3}$ & $150-160$ & 35.3 & 35.7 & Formaldehyde \\
\hline $\mathrm{EtOH}$ & $\mathrm{Cr}(\mathrm{OEt})_{3}$ & 80 & 27.5 & 27.8 & Acetaldehyde \\
\hline $\mathrm{Pr}^{\mathrm{n}} \mathrm{OH}$ & $\mathrm{Cr}\left(\mathrm{OPr}{ }^{\mathrm{n}}\right)$ & $120-130$ & 22.5 & 22.7 & Propionaldehyde \\
\hline $\mathrm{Bu}^{\mathrm{n}} \mathrm{OH}$ & $\mathrm{Cr}\left(\mathrm{OBu}^{\mathrm{n}}\right)$ & 80 & 19.1 & 19.2 & n-Butyraldehyde \\
\hline $\operatorname{Pr}^{i} \mathrm{OH}$ & $\mathrm{Cr}\left(\mathrm{OPr}^{\mathrm{i}}\right)$ & 60 & 22.3 & 22.7 & Acetone \\
\hline
\end{tabular}


III $-3 \quad \mathrm{Cr}(\mathrm{VI})+\mathrm{ROH}\langle--->\mathrm{Cr}(\mathrm{VI}) \mathrm{OR}$

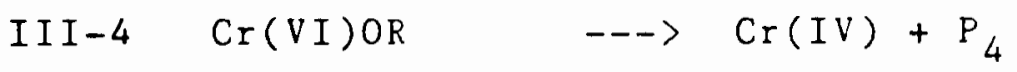

III-5 $\mathrm{Cr}(\mathrm{IV})+\mathrm{ROH} \rightarrow-\mathrm{Cr}(\mathrm{III})+\mathrm{R}^{*}$

III-6 $R^{\bullet}+\operatorname{Cr}(\mathrm{VI}) \quad-\rightarrow \mathrm{Cr}(\mathrm{V})+\mathrm{P}_{6}$

$\mathrm{III}-7 \quad \mathrm{Cr}(\mathrm{V})+\mathrm{ROH} \quad \rightarrow \quad \mathrm{Cr}(\mathrm{III})+\mathrm{P}_{5}$

$\left[\mathrm{P}_{4}, \mathrm{P}_{5}\right.$ and $\mathrm{P}_{6}=$ Organic Products]

Both Rocek and Trahanovsky have defined the role of Cr(IV) on the basis of disproportionation reactions. When cyclobutanol was introduced into this system under conditions in which its reaction with $\operatorname{Cr}(V I)$ is slow, the formation of an organic oxidation product, gamma-hydroxybutyraldehyde, was observed(35).

The use of $\mathrm{Cr}\left(\mathrm{OC}_{4} \mathrm{H}_{9}\right)_{4}$ in the oxidation of alcohols and selected metal and non-metal ions have also been studied; see Table XI.

A mechanism for the chromium(IV) oxijation reaction has been postulated as follows(15):
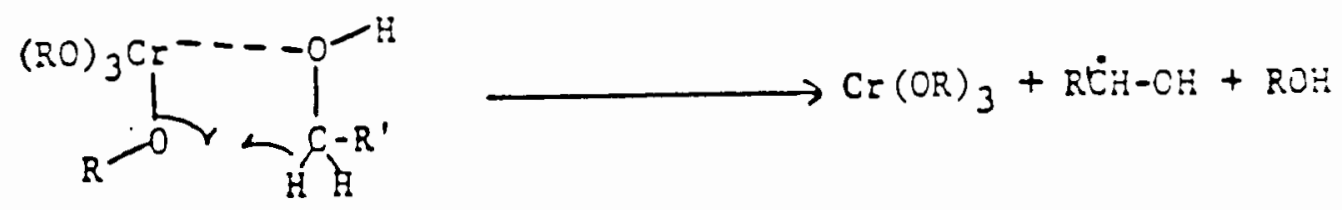

$$
\begin{aligned}
& \mathrm{R}^{\prime} \dot{\mathrm{CH}}-\mathrm{CH}+\left(\mathrm{R}^{\prime} \mathrm{CH}_{2}-\mathrm{O}-\right) \mathrm{Cr}(\mathrm{CR})_{3} \longrightarrow \mathrm{RCH}_{2} \mathrm{OH}+\left(\mathrm{R}^{\prime} \dot{\mathrm{CH}}-\mathrm{O}-\right) \mathrm{Cr}(\mathrm{OB})
\end{aligned}
$$

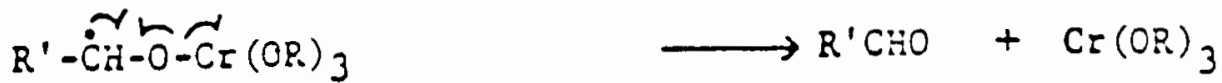

prinary 1sotope effect of 1.6 to $2.4 \mathrm{k}_{\mathrm{H}} / \mathrm{k}_{\mathrm{D}}$ 
TABLE XI

Reactants

$\underline{\text { Product }}$

Cr(IV)-t-butoxide + primary alcohol $--\rightarrow \operatorname{Cr}(I I I)+$

A1dehyde

$\operatorname{Cr}(I V)+$ secondary a 1 cohol

$-->\operatorname{Cr}(\mathrm{III})+$ Ketone

$\mathrm{Cr}(\mathrm{IV})+$ Pheno1s

$--\rightarrow \operatorname{Cr}(I I I)+$

Hydroquinones

$\mathrm{Cr}(\mathrm{IV})+\mathrm{I}^{-}$

$-->\operatorname{Cr}(\mathrm{III})+\mathrm{I}_{2}$

$\mathrm{Cr}(\mathrm{IV})+\mathrm{Fe}(\mathrm{II})$

$-->\operatorname{Cr}(\mathrm{III})+\mathrm{Fe}(\mathrm{III})$

$\mathrm{Cr}(\mathrm{IV})+\mathrm{Sn}(\mathrm{II})$

$-\rightarrow \operatorname{Cr}(\mathrm{III})+\mathrm{Sn}(\mathrm{IV})$ 
In the reaction with fluorinated alcohols, it was our hope to isolate new fluorinated $\mathrm{Cr}$ (IV) compounds. Instead, in all cases the results were not satisfactory. The products contained $\operatorname{Cr}$ (III) systems and other side reaction products that were not easily separated and consequently, were not well characterized.

In reactions with $\mathrm{HF}$, the presence of $\mathrm{CrF}_{4}$ was doubtful. Attempts to sublime the brown solid product obtained, resulted in the formation of a viscous liquid which evidently affected the sublimation process. This prevented further purification and characterization of the products. A similar difficulty was encountered in the $\mathrm{CF}_{3}$ COOAg reaction.

The reactions of $\mathrm{Cr}\left(\mathrm{OC}_{4} \mathrm{H}_{9}\right)_{4}, \mathrm{C}_{6} \mathrm{~F}_{5} \mathrm{OH}$ and $\left(\mathrm{C}_{6} \mathrm{H}_{5}\right)_{3} \mathrm{SiOH}$ resulted in the formation of products not fully characterized. There were associated difficulties in purification and separation of the products obtained. In most cases, the presence of $\operatorname{Cr}($ III) was detected.

The reactions of $\mathrm{Cr}\left(\mathrm{OC}_{4} \mathrm{H}_{9}\right)_{4}$, while they did not yield the desired products, revealed a lot of information on the chemistry of the transition metal alkoxides in the +4 oxidation state and in particular, the $\operatorname{Cr}$ (IV) alkoxide. The high stability, high rate of hydrolysis, low degree of polymerization and slowness to alcoholysis characteristic of chromium(IV) alkoxides were manifested in these 
reactions. Owing to the hydrolytic and light sensitivity of $\mathrm{Cr}\left(\mathrm{OC}_{4} \mathrm{H}_{9}\right)_{4}$, reactions were generally carried out in thoroughly dried vessels, well-shielded from light. Solvents were distilled with appropriate drying agents. The major factor affecting these reactions is presumably steric hinderance. With the bulky t-butyl group in $\mathrm{Cr}\left(\mathrm{OC}_{4} \mathrm{H}_{9}\right)_{4}$, exchange reactions for example, were highly hindered.

EXPERIMENTAL.

Preparation of $\underline{\mathrm{CrF}}_{5}$. To 32.0 mmole of pre-dried $\mathrm{CrF}_{3}$ in a passivated $100 \mathrm{ml}$ Monel vessel equipped with two stainless steel ball bearings and a Whitey stainless steel valve, was added 156 mmole of $\mathrm{F}_{2}$. The reaction vessel was maintained at $270-303^{\circ} \mathrm{C}$ for 29 hours with shaking at 15 minute intervals. The vessel was later cooled to $-196^{\circ} \mathrm{C}$ for 4 minutes and the top heated so as to move any $\mathrm{CrF}_{5}$ trapped on the top sides of the vessel. The vessel was then brought up to $-78^{\circ} \mathrm{C}$ to remove any excess $\mathrm{F}_{2} \cdot 32.0$ mmole of red $\mathrm{CrF}_{5}$ ( $100 \%$ yield based on $\mathrm{CrF}_{3}$ ) was obtained. Preparation of $\mathrm{CrF}_{4}$.

To 32.0 mmole of $\mathrm{CrF}_{5}$ was added 16 mmole of $\mathrm{Cl}_{2}$ in a $100 \mathrm{ml}$ Monel vessel equipped with two stainless steel ball bearings and a Whitey stainless steel valve. The reaction vessel was heated at $183^{\circ} \mathrm{C}$ for 22 hours with intermittent 
shaking. Excess $\mathrm{Cl}_{2}, \mathrm{C} 1 \mathrm{~F}$ and $\mathrm{ClF}_{3}$ were removed at $-78^{\circ} \mathrm{C}$ after condensing all trapped $\mathrm{CrF}_{4}$ at $-196^{\circ} \mathrm{C} ; 32.0$ mmole of trapped $\mathrm{CrF}_{4}\left(100 \%\right.$ yield based on $\mathrm{CrF}_{5}$ ) was obtained. The infrared spectrum of $\mathrm{CrF}_{4}$, see appendix, contained the following absorptions: 730-845(s), 470-642(m).

Preparation of $\underline{\mathrm{Cr}}\left(\underline{\mathrm{OC}}_{\underline{4}} \underline{\mathrm{H}}_{9}\right)_{\underline{4}}$ :

$\mathrm{Cr}\left(\mathrm{OC}_{4} \mathrm{H}_{9}\right)_{4}$ was prepared through the alcoholysis of $\mathrm{Cr}\left(\mathrm{NEt}_{2}\right)_{4}$. Different methods were adapted for the preparation of $\operatorname{Cr}\left(\mathrm{NEt}_{2}\right)_{4}{ }^{\circ}$ However, in the method frequently employed in this study, 42.3 mole of $\mathrm{CrCl}_{3}$ was dissolved in $50 \mathrm{ml}$ THF and slowly added to 126.8 mmole of LiNEt 2 in $50 \mathrm{ml}$ diethyl ether at $-20^{\circ} \mathrm{C}$. The mixture was maintained at $-20^{\circ} \mathrm{C}$ for 10 minutes. It was then slowly brought to room temperature and stirred for 20 hours. After removing the solvent in vacuo, the green solid was extracted with $30 / 60$ petroleum ether. The bulk of the petroleum ether was removed in vacuo, leaving a dark green viscous liquid which was treated with 274.4 mmole of tert-butanol dissolved in $75 \mathrm{~m} 1$ petroleum ether under the conditions of reflux for 60 minutes. Upon removal of the solvent in vacuo, $4.43 \mathrm{~g}$ of a dark blue solid was obtained. The infrared spectrum of the blue solid consists of absorptions at 2973(s), 2924(mw), 1560(vw), $1461(\mathrm{mw}), \quad 1384(\mathrm{mw}), \quad 1356(\mathrm{~ms}), 1229(\mathrm{~m}), 1160(\mathrm{~s}), 1124(\mathrm{~m})$, $1025(\mathrm{w}), 927(\mathrm{vs}), 899(\mathrm{~m}), 786(\mathrm{~s}), 625(\mathrm{~s})$, and $470(\mathrm{~m}) \mathrm{cm}^{-1}$. 


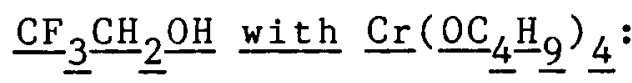

To a three neck $100 \mathrm{ml}$ round bottom flask containing $45 \mathrm{ml}$ benzene was dissolved 4.848 mmole $\mathrm{Cr}\left(\mathrm{OC}_{4} \mathrm{H}_{9}\right)_{4} \cdot 23.84$ mmole of $\mathrm{CF}_{3} \mathrm{CH}_{2} \mathrm{OH}$ was added dropwise and a refluxing unit was connected. After refluxing at $75-80^{\circ} \mathrm{C}$ temperature for 24 hours there was no appreciable change from the initial green color formed upon mixing, the refluxing was continued for 20 days. The color changed slowly from green to dark green during the refluxing. At the end of the refluxing, the solvent was removed in vacuo and a deep green solid $(1.0 \mathrm{~g})$ was left behind. The solid decomposed without melting at $190^{\circ} \mathrm{C}$. The infrared spectrum of the product (see appendix) was similar to that found when $\mathrm{Cr}\left(\mathrm{NEt}_{2}\right)_{3}$ reacted with $\mathrm{CF}_{3} \mathrm{CH}_{2} \mathrm{OH}$ (see appendix). Analysis of the trap materials showed the presence of the starting alcohol and the solvent.

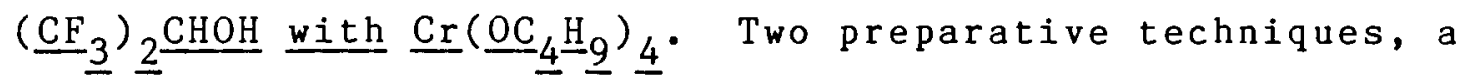
and $b$, were employed:

a. To a $75 m 1$ Pyrex glass vessel equipped with a Kontes Teflon valve and a Teflon stirring bar was added 1.631 mmole of $\mathrm{Cr}\left(\mathrm{OC}_{4} \mathrm{H}_{9}\right)_{4}$. The reaction vessel was briefly pumped on the vacuum line before 13.27 mmole of $\left(\mathrm{CF}_{3}\right)_{2} \mathrm{CHOH}$ was condensed at $-196^{\circ} \mathrm{C}$. The reaction vessel was allowed to attain room temperature and then stirred for 11 hours. 
After checking for volatile materials, the solvent was removed in vacuo leaving 0.720 g of a brown solid which was dried in vacuo for several hours. The infrared spectrum of the volatile materials showed the presence of unreacted alcohol. The brown solid was stable to $360^{\circ} \mathrm{C}$ and did not sublime when subjected to vacuum sublimation at $200^{\circ} \mathrm{C}$. Interestingly, the infrared spectrum (see appendix) of this solid was found to be similar to the green solid obtained in part $b$ after it has been extracted (by R. Sheets) with $\mathrm{CCl}_{4}$. However, the result obtained when the same alcohol reacted with $\mathrm{Cr}\left(\mathrm{NEt}_{2}\right)_{3}$ was different in its infrared patterns.

b. To a $200 \mathrm{ml}$ round bottomed flask equipped with a Teflon stirring bar was added 4.651 mmole of $\mathrm{Cr}\left(\mathrm{OC}_{4} \mathrm{H}_{9}\right)_{4}$ and $50 \mathrm{~m} 1$ of benzene. The reaction vessel was flushed with $\mathrm{N}_{2}$ and 22.14 mmole of $\left(\mathrm{CF}_{3}\right)_{2} \mathrm{CHOH}$ was added. The resulting dark mixture was refluxed at $50-60^{\circ} \mathrm{C}$ for 25 days. During the refluxing period, the mixture turned from blue to blue-green and finally $1.0 \mathrm{~g}$ of a moist-looking dark-green solid was formed. After removing solvent and volatile materials in vacuo, the green solid was dried for several hours. The infrared spectrum of the volatile materials showed the presence of the starting alcohol and the solvent. The solid was soluble in 
benzene, THF and hydrolyzed in $\mathrm{H}_{2} \mathrm{O}$. It was stable in air and decomposed without melting at $182^{\circ} \mathrm{C}$.

\section{$\left(\underline{\mathrm{CF}}_{3}\right)_{3} \underline{\mathrm{COH}}$ with $\underline{\mathrm{Cr}}\left(\underline{\mathrm{OC}}_{4} \underline{\mathrm{H}}_{9}\right)_{4} \cdot$}

To a 75 ml Pyrex glass vessel equipped with a Kontes Teflon valve and Teflon stirring bar, was added 0.431 mmole of $\mathrm{Cr}\left(\mathrm{OC}_{4} \mathrm{H}_{9}\right)_{4}$ and 2.966 mmole of $\left(\mathrm{CF}_{3}\right)_{3} \mathrm{COH}$. The reaction vessel was warmed up slowly from $-196^{\circ} \mathrm{C}$ to $0^{\circ} \mathrm{C}$. Formation of a green colored solid was noticed within 10 minutes at $0^{\circ} \mathrm{C}$. After removing the volatile materials in vacuo, the recovered green solid was pumped for several hours to dryness. $0.0376 \mathrm{~g}$ was obtained. The infrared spectrum of the volatile materials showed the presence of the unreacted alcohol. Other than taking the IR spectrum of this solid, the reaction was not further studied.

$\underline{\mathrm{C}}_{6} \underline{\mathrm{F}}_{5} \underline{\mathrm{OH}}$ with $\mathrm{Cr}\left(\underline{\mathrm{OC}}_{4} \underline{\mathrm{H}}_{9}\right)_{\underline{4}} \cdot$

To a $100 \mathrm{ml} 3$-necked round bottomed flask equipped with a Telfon stirring bar was added 1.860 mmole of $\mathrm{Cr}\left(\mathrm{OC}_{4} \mathrm{H}_{9}\right)_{4}$ dissolved in $15 \mathrm{ml}$ benzene and stirred under nitrogen. $\quad 9.890$ mmole of $\mathrm{C}_{6} \mathrm{~F}_{5} \mathrm{OH}$ dissolved in $10 \mathrm{ml}$ benzene was added dropwise to the stirring $\mathrm{Cr}\left(\mathrm{OC}_{4} \mathrm{H}_{9}\right)_{4}$ solution in the hood. The reaction was slowly warmed to $63^{\circ} \mathrm{C}$ in a water bath. A green compound formed after two hours at this temperature. The infrared spectrum of the trap materials showed the presence of the starting 
alcohol. After removing solvent and volatile materials in vacuo, $0.32 \mathrm{~g}$ of a green solid was obtained. The IR spectrum of this solid, (see appendix) was not conclusive and the reaction was not studied further.

\section{$\left(\underline{\mathrm{C}}_{6} \underline{\mathrm{H}}_{5}\right)^{3} \underline{\mathrm{SiOH}}$ with $\underline{\mathrm{Cr}}\left(\underline{\mathrm{OC}}_{4} \underline{\mathrm{H}}_{9}\right) \underline{4}^{\circ}$}

To a $100 \mathrm{ml} 3$-neck round bottomed flask equipped with a Teflon stirring bar was added 0.291 mmole of $\mathrm{Cr}\left(\mathrm{OC}_{4} \mathrm{H}_{9}\right)_{4}$ and $15 \mathrm{~m} 1$ of benzene. Under nitrogen, 1.154 mmole of $\left(\mathrm{C}_{6} \mathrm{H}_{5}\right)_{3} \mathrm{SiOH}$ dissolved in $10 \mathrm{ml}$ of benzene was added dropwise and allowed to stir for 15 minutes. A refluxing apparatus was connected and the mixture was refluxed at $75-80^{\circ} \mathrm{C}$ for one hour. Analysis of the volatile materials showed the presence of a mixture of unreacted alcohol and benzene. The green solid obtained after removing solvent in vacuo was dried for several hours. The solid was insoluble in common solvents and decomposed at $230^{\circ} \mathrm{C}$ without melting. An IR spectrum (see appendix) of the solid was not conclusive and further studies were not undertaken.

$\underline{\mathrm{HF}}$ with $\underline{\mathrm{Cr}}\left(\underline{\mathrm{OC}}_{\underline{4}} \underline{\mathrm{H}}_{9}\right)_{\underline{4}}$.

To a $35 \mathrm{ml}$ Kel-F reaction vessel fitted with a Whitey brass valve and a brass $10 / 30$ inner joint was added 7.171 mmole of $\mathrm{Cr}\left(\mathrm{OC}_{4} \mathrm{H}_{9}\right)_{4} \cdot 79.0$ mmole of $\mathrm{HF}$ was condensed into the reaction vessel at $-196^{\circ} \mathrm{C}$. The reaction vessel 
was allowed to warm up to room temperature. On warming slowly, different colors were noted-dark blue, blue-green and green. Upon stirring, presumably HF fumes were noted in the reaction vessel. After 6 hours at room temperature, volatile materials were removed in vacuo leaving $1.67 \mathrm{~g}$ brown solid. An attempt was made to sublime the solid in vacuo at different temperatures: $55^{\circ} \mathrm{C}(4$ min. $), 60^{\circ} \mathrm{C}(11 \mathrm{min.}), 67^{\circ} \mathrm{C}(25 \mathrm{~min}$.$) and slowly to 171^{\circ} \mathrm{C}$ (20 min.). Although the solid did not sublime, some viscous liquid material was seen on the sides of the reaction vessel. Attempt to obtain an IR sample of these viscous material was not successful. The solid was stable in air but hydrolyzed in water, forming a yellow-green mixture. It was stable to $360^{\circ} \mathrm{C}$ and was slightly soluble in benzene, THF and carbon tetrachloride. The infrared spectrum is shown in the appendix. Analysis of the product indicated that possibly a mixed alkoxide fluoride, $\mathrm{Cr}\left[\left(\mathrm{CH}_{3}\right)_{3} \mathrm{CO}\right]_{2} \mathrm{~F}_{2}$ (not $\left.\mathrm{CrF}_{4}\right)$ was produced. The peak at $498 \mathrm{~cm}^{-1}$ indicated strongly the presence of a $\mathrm{Cr}-\mathrm{F}$ bond. Thus, based on the product yield, a partial exchange reaction presumably occurred during the reaction.

\section{$\underline{\mathrm{CF}}_{3} \underline{\mathrm{COOAg}}$ with $\mathrm{Cr}\left(\underline{\mathrm{OC}}_{4} \underline{\mathrm{H}}_{9}\right)_{4} \underline{4}^{\circ}$}

To a 75 ml Pyrex glass vessel equipped with a Kontes Teflon valve and a Teflon stirring bar, 0.6387 mmole of $\mathrm{Cr}\left(\mathrm{OC}_{4} \mathrm{H}_{9}\right)_{4}$ was added and stirred in $15 \mathrm{ml}$ of benzene. The 
reaction mixture was stirred at room temperature while 1.973 mmole of $\mathrm{CF}_{3} \mathrm{COOAg}$ dissolved in $10 \mathrm{ml}$ benzene was slowly added. A constant nitrogen (gas) supply was maintained for 20 minutes. A greenish compound resulted within 30 minutes. The mixture was slowly heated to $70^{\circ}$ in a water bath and then left overnight. Upon removal of the solvent in vacuo, $0.450 \mathrm{~g}$ green-brown solid was obtained, with a melting point of $238-244^{\circ} \mathrm{C}$. The infrared spectrum of the solid (see appendix) was not conclusive and further studies were not undertaken.

$\underline{\mathrm{CF}}_{3} \underline{\mathrm{CH}}_{2} \underline{\mathrm{OH}}$ with $\underline{\mathrm{Cr}}\left(\underline{\mathrm{NEt}}_{2}\right)_{3}{ }^{\circ}$

To a $100 \mathrm{~m} 1$ round bottomed flask equipped with a Teflon stirring bar was added 3.358 mmole of $\mathrm{Cr}\left(\mathrm{NEt}_{2}\right)_{3}$ dissolved in pentane. 14.80 mmole of $\mathrm{CF}_{3} \mathrm{CH}_{2} \mathrm{OH}$ was added dropwise, each drop resulting in an immediate formation of a purple-brown solid. The reaction vessel was flushed with $\mathrm{N}_{2}$ gas and refluxed at $36^{\circ} \mathrm{C}$ for one hour and then stirred at room temperature for 18 hours. After removing solvent and volatile materials in vacuo, the brown solid was washed with dried $\mathrm{CH}_{2} \mathrm{Cl}_{2}$ to remove the amine by-product. The infrared spectrum of the volatile materials indicated the presence of the solvent. The brown solid left behind weighed $0.710 \mathrm{~g}$. The solid was soluble in $\mathrm{CH}_{2} \mathrm{Cl}_{2}$, slightly soluble in Freon-1l and 
decomposed with slight melting at $166^{\circ} \mathrm{C}$. IR spectrum of the solid was obtained and analyzed (see appendix).

\section{$\left(\underline{\mathrm{CF}}_{3}\right)_{2} \underline{\mathrm{CHOH}}$ with $\underline{\mathrm{Cr}}\left(\underline{\mathrm{NEt}}_{2}\right)_{3} \underline{3}^{.}$}

To a 250 ml round bottomed flask equipped with a Teflon stirring bar was added 4.104 mmole of $\mathrm{Cr}\left(\mathrm{NEt}_{2}\right)_{3}$ dissolved in pentane. 16.66 mmole of $\left(\mathrm{CF}_{3}\right)_{2} \mathrm{CHOH}$ was added dropwise, each drop resulting in the formation of brown fumes and a purple brown solid. The reaction vessel was flushed with $\mathrm{N}_{2}$ gas, refluxed for one hour and then stirred at room temperature for 18 hours. After removing solvent and volatile materials in vacuo, the brown solid obtained was washed with $\mathrm{CH}_{2} \mathrm{Cl}_{2}$ to remove the amine by-product. The infrared spectrum of the volatile materials showed the presence of the solvent and the alcohol. The $1.720 \mathrm{~g}$ brown solid left behind was soluble in $\mathrm{CH}_{2} \mathrm{Cl}_{2}$ and Freon-11 and has a melting point of 99- $100^{\circ} \mathrm{C}$. IR spectrum of the solid was obtained and analyzed (see appendix).

INFRARED SPECTRA.

The infrared absorptions are tabulated in Table XII and the actual spectra are shown in the Appendix. For the fluorinated compounds, strong absorptions observed in the region 1145-1305 $\mathrm{cm}^{-1}$ were attributable to the C-F stretching frequency $(49,50)$. Therefore in these solids 


\section{TABLE XII}

INFRARED ABSORPTION BANDS FOR $\mathrm{Cr}(\mathrm{IV}) / \mathrm{Cr}$ (III)

$$
\left(\mathrm{cm}^{-1}\right) * *
$$

$\mathrm{CrF}_{4}$

$$
\begin{aligned}
& 470(\mathrm{~m}), 530(\mathrm{~s}, \mathrm{~b}), 580(\mathrm{~m}), \\
& 648(\mathrm{~m}), 750(\mathrm{~ms}), 810(\mathrm{~m}),
\end{aligned}
$$$$
845(\mathrm{~m}) \text {. }
$$

$\mathrm{CF}_{3} \mathrm{CH}_{2} \mathrm{OH}$ with $\mathrm{Cr}\left(\mathrm{OC}_{4} \mathrm{H}_{9}\right)_{4}$

$$
\begin{aligned}
& 2938(\mathrm{~m}), 2882(\mathrm{w}, \mathrm{sh}), \\
& 1454(\mathrm{w}), 1278(\mathrm{~m}), 1204(\mathrm{~m}, \mathrm{sh}), \\
& 1165(\mathrm{vs}), 1104(\mathrm{~s}, \mathrm{sh}) \\
& 961(\mathrm{~s}), 899(\mathrm{w}), 831(\mathrm{~m}), \\
& 796(\mathrm{w}), 739(\mathrm{w}), 686(\mathrm{~m}), \\
& 676(\mathrm{~m}), 595(\mathrm{w}, \mathrm{b}), 475(\mathrm{~m}) .
\end{aligned}
$$

$\left(\mathrm{CF}_{3}\right)_{2} \mathrm{CHOH}$ with $\mathrm{Cr}\left(\mathrm{OC}_{4} \mathrm{H}_{9}\right)_{4}$

$$
\begin{aligned}
& 1616(\mathrm{~b}), 1468(\mathrm{w}), 1363(\mathrm{~s}), \\
& 1278(\mathrm{~s}), 1257(\mathrm{mw}), 1215(\mathrm{~m}), \\
& 1180(\mathrm{vs}), 1131(\mathrm{~s}, \mathrm{sh}), \\
& 1089(\mathrm{~s}), 969(\mathrm{w}), 892(\mathrm{~m}), \\
& 857(\mathrm{~s}), 744(\mathrm{~s}), 688(\mathrm{~s}), \\
& 667(\mathrm{w}), 533(\mathrm{~m}) .
\end{aligned}
$$

$\left(\mathrm{CF}_{3}\right)_{3} \mathrm{COH}$ with $\mathrm{Cr}\left(\mathrm{OC}_{4} \mathrm{H}_{9}\right)_{4}$

$$
\begin{aligned}
& 2973(\mathrm{~m}), 1700(\mathrm{w}), 1616(\mathrm{mw}), \\
& 1462(\mathrm{w}), 1370(\mathrm{~m}), 1250(\mathrm{vs}), \\
& 1201(\mathrm{~s}), 1166(\mathrm{~s}), 1124(\mathrm{w}, \mathrm{sh}), \\
& 962(\mathrm{vs}), 899(\mathrm{w}), 744(\mathrm{w}), \\
& 723(\mathrm{~s}), 533(\mathrm{w}) .
\end{aligned}
$$

* m=medium, s=strong, vs=very strong, sh=shoulder, $w=w e a k$, ms=medium strong, mw=medium weak, b=broad. 
TABLE XII (cont.)

$\mathrm{C}_{6} \mathrm{~F}_{5} \mathrm{OH}$ with $\mathrm{Cr}\left(\mathrm{OC}_{4} \mathrm{H}_{9}\right)_{4}$

$$
\begin{aligned}
& 1698(\mathrm{~m}), 1653(\mathrm{vw}), 1501(\mathrm{vs}), \\
& 1468(\mathrm{~s}, \mathrm{sh}), 1377(\mathrm{vw}), 1196(\mathrm{w}), \\
& 1162(\mathrm{~ms}), 1123(\mathrm{~m}), 1044(\mathrm{~m}, \mathrm{sh}), \\
& 790(\mathrm{vs}), 893(\mathrm{w}, \mathrm{b}), 763(\mathrm{vw}), \\
& 739(\mathrm{~m}), 645(\mathrm{w}), 581(\mathrm{w}, \mathrm{b}), \\
& 505(\mathrm{w}, \mathrm{b}) .
\end{aligned}
$$

$\left(\mathrm{C}_{6} \mathrm{H}_{5}\right)_{3} \mathrm{SiOH}$ with $\mathrm{Cr}\left(\mathrm{OC}_{4} \mathrm{H}_{9}\right)_{4}$

$2973(w), 2924(w), 1960(m)$,

$1890(\mathrm{~m}), 1778(\mathrm{w}), 1665(\mathrm{w})$,

$1588(\mathrm{~s}), 1567(\mathrm{w}), 1482(\mathrm{~s})$,

$1426(\mathrm{~s}), 1377(\mathrm{mw}), 1335(\mathrm{mw})$,

$1257(\mathrm{w}), 1187(\mathrm{~m}, \mathrm{sh}), 1117(\mathrm{~m})$,

$997(w), 969(m, b), 892(m, b)$,

$737(\mathrm{~m}), 695(\mathrm{~m}), 632(\mathrm{vw})$,

$596(\mathrm{~m}), 547(\mathrm{w}), 499(\mathrm{~m})$,

$463(\mathrm{w}), 435(\mathrm{~ms}), 414(\mathrm{vw})$.

$\mathrm{HF}$ with $\mathrm{Cr}\left(\mathrm{OC}_{4} \mathrm{H}_{9}\right)_{4}$

$2959(\mathrm{~s}), 2868(\mathrm{~m}, \mathrm{sh}), 1637(\mathrm{~m}, \mathrm{~b})$, $1468(\mathrm{~s}), 1364(\mathrm{~s}), 1201(\mathrm{~s})$,

$1124(\mathrm{w}), 969(\mathrm{~m}), 899(\mathrm{mw})$,

$498(\mathrm{~m}, \mathrm{~b})$.

$\mathrm{CF}_{3} \mathrm{COOAg}$ with $\mathrm{Cr}\left(\mathrm{OC}_{4} \mathrm{H}_{9}\right)_{4}$

$$
\begin{aligned}
& 2980(\mathrm{w}), 1785(\mathrm{vw}, \mathrm{sh}), 1679(\mathrm{vs}), \\
& 1475(\mathrm{w}), 1433(\mathrm{~s}), 1370(\mathrm{~s}), \\
& 1194(\mathrm{vs}), 1124(\mathrm{~s}), 962(\mathrm{~ms}), \\
& 899(\mathrm{~m}), 850(\mathrm{~m}), 793(\mathrm{~ms}), \\
& 723(\mathrm{~s}), 653(\mathrm{w}), 617(\mathrm{~m}), 596(\mathrm{w}), \\
& 519(\mathrm{~m}), 463(\mathrm{~m}) .
\end{aligned}
$$


TABLE XII (cont.)

$\mathrm{CF}_{3} \mathrm{CH}_{2} \mathrm{OH}$ with $\mathrm{Cr}\left(\mathrm{NEt}_{2}\right)_{3}$

$$
\begin{aligned}
& 2973(\mathrm{w}), 2924(\mathrm{mw}), 2846(\mathrm{mw}), \\
& 1616(\mathrm{~m}, \mathrm{~b}), 1454(\mathrm{~m}), 1384(\mathrm{w}), \\
& 1271(\mathrm{~s}), 1201(\mathrm{w}), 1124(\mathrm{vs}), \\
& 955(\mathrm{vs}), 894(\mathrm{mw}), 828(\mathrm{~ms}), \\
& 674(\mathrm{~ms}), 512(\mathrm{~m}, \mathrm{~b}) .
\end{aligned}
$$

$\left(\mathrm{CF}_{3}\right)_{2} \mathrm{CHOH}$ with $\mathrm{Cr}\left(\mathrm{NEt}_{2}\right)_{3}$

$$
\begin{aligned}
& 2980(\mathrm{~m}), 2938(\mathrm{~m}), 2875(\mathrm{~m}), \\
& 1609(\mathrm{mw}), 1461(\mathrm{w}, \mathrm{sh}), 1510(\mathrm{~s}), \\
& 1457(\mathrm{w}), 1440(\mathrm{~ms}), 1321(\mathrm{~ms}), \\
& 1278(\mathrm{~s}), 1250(\mathrm{~m}), 1208(\mathrm{~ms}), \\
& 1166(\mathrm{vs}), 1089(\mathrm{~s}), 976(\mathrm{~m}), \\
& 941(\mathrm{w}), 786(\mathrm{~m}), 744(\mathrm{~s}), \\
& 681(\mathrm{vs}), 639(\mathrm{w}), 533(\mathrm{~m}) .
\end{aligned}
$$


containing fluoroligands, the absorptions at 1124 to 1321 $\mathrm{cm}^{-1}$ are attributable to $\mathrm{C}-\mathrm{F}$ stretching frequencies. Also the absorptions at 723 to $744 \mathrm{~cm}^{-1}$ are ascribed to $\mathrm{CF}_{3}$ deformation modes usually observed at 715 to 750 $\mathrm{Cm}^{-1}(50)$. The metal oxygen $(M-0)$ stretching vibrations are generally below $650 \mathrm{~cm}^{-1}(48)$ and thus the characteristic absorptions observed below $650 \mathrm{~cm}^{-1}$ are attributable to these bands. In the compounds formed from the reactions of $\mathrm{Cr}\left(\mathrm{OC}_{4} \mathrm{H}_{9}\right)_{4}$ with $\mathrm{HF},\left(\mathrm{C}_{6} \mathrm{H}_{5}\right)_{3} \mathrm{SiOH}, \mathrm{CF}_{3} \mathrm{COOAg}$ and $\mathrm{C}_{6} \mathrm{~F}_{5} \mathrm{OH}$ other absorptions not fully characterized are noted.

Due to incomplete exchange/oxidation reactions in some alcohol compounds, absorptions at 3300 to $3600 \mathrm{~cm}^{-1}$ are attributable to $0-H$ bands with their associated deformation modes at 1000 to $1300 \mathrm{~cm}^{-1}(39)$. The latter absorptions are masked by the stronger C-F absorptions in the case of fluorinated alcohols.

Summary/Conclusion.

The study of $\mathrm{Cr}(\mathrm{IV})$ tetrafluoride was conducted in part with Dr. Kenneth Hedberg at the Oregon State University in order to determine its structure in the gas phase. Previously, Dr. Gard's group at Portland State University has worked with Dr. Hedberg's group in studying the structures of $\mathrm{CrO}_{2} \mathrm{~F}_{2}$ and $\mathrm{CrF}_{5}$. A summary of their 
results show that for $\mathrm{CrO}_{2} \mathrm{~F}_{2}$, the $\mathrm{Cr}-\mathrm{F}$ has a single bond length of 1.71A. The length of the $\mathrm{Cr}=0$ double bond was found to be $1.56 \mathrm{~A}(1)$. Observed values were close to calculated values, for single $\mathrm{Cr}-\mathrm{F}$ and double $\mathrm{Cr}=0$ bonds. Similar conclusion was reached in the case of the bond types in $\mathrm{CrO}_{2} \mathrm{Cl}_{2}(40)$. It was also found that chromyl halides, unlike the sulfonyl halides, in general, did not obey the valence shell electron-pair repulsion (VSEPR) theory. In the chromyl halides, the angle between the bonds to the oxygen atom is found to be slightly smaller than that between halogen bonds(1). Both Garner et al, and Beattie et al,, in comparing $F-M-F$ ( $M=S$ or $C r$ ) angles in $\mathrm{SO}_{2} \mathrm{~F}_{2}$ and $\mathrm{CrO}_{2} \mathrm{~F}_{2}$, observed that coulombic repulsion between the fluorine atoms should be greater in $\mathrm{CrO}_{2} \mathrm{~F}_{2}$ than in $\mathrm{SO}_{2} \mathrm{~F}_{2}$ due to the larger atomic charges in $\mathrm{CrO}_{2} \mathrm{~F}_{2}(41,42)$.

For $\mathrm{CrF}_{5}$, Dr. Hedberg's group found that the average symmetry of $\mathrm{CrF}_{5}$ molecule was appreciably different from $\mathrm{D}_{3}$ h symmetry. The average bond angles in $\mathrm{CrF}_{5}$ are significantly distorted $\left(3^{\circ}-10^{\circ}\right)$ from the trigonal bipyramida1 values( 6$)$.

Following the above studies, it became of interest to determine the gas phase structure of $\mathrm{CrF}_{4} \cdot \mathrm{Dr}$. Hedberg's group have completed the experimental studies and preliminary analysis favors a tetrahedral structure for 
$\mathrm{CrF}_{4^{\circ}}$ Earlier matrix isolation IR studies(43) also favored a tetrahedral structure. The magnitude of the $\mathrm{Cr}^{50}-\mathrm{Cr}^{54}$ separation $\left(10.0 \mathrm{~cm}^{-1}\right)$ indicates a tetrahedral rather than a square planar. Tetrahedral $\mathrm{CrF}_{4}$ would be expected to have a ${ }^{3} \mathrm{~A}_{2}$ group state, and should not show any static Jahn-Teller distortions. The absorptions found at 784.3 and $303 \mathrm{~cm}^{-1}$ in the matrix study, were assigned as the $\mathrm{T}_{2}$ stretch and $\mathrm{T}_{2}$ bend respectively, and the assignment was supported by an analysis of the isotope pattern for the stretch(43).

Chromium(IV) Butoxides.

The study on $\operatorname{Cr}($ IV $)$ butoxides was primarily undertaken in order to prepare and characterize other Cr(IV) derivatives through simple exchange reactions. Our results show that $\operatorname{Cr}($ IV) butoxide was not a useful reagent for preparing other $\operatorname{Cr}(I V)$ systems. Our results with $\mathrm{CF}_{3} \mathrm{COOAg}, \mathrm{CF}_{3} \mathrm{CH}_{2} \mathrm{OH}$, and $\mathrm{HF}$ indicate strong evidence of oxidation/decomposition reactions. The knowledge obtained from $\operatorname{Cr}($ IV) oxidation of alcohols, coupled with the instability of $\mathrm{Cr}(\mathrm{IV})$ compounds and steric effects, have enabled us to associate these oxidation reactions with possible decomposition reactions.

$\underline{\mathrm{Cr}}\left(\underline{\mathrm{NEt}}_{2}\right)_{3}-\underline{\mathrm{Cr}}(\underline{\mathrm{OR}})_{3}$

Since the $\operatorname{Cr}(I V)$ systems were resulting in 
oxidation/decomposition products, it was decided to look into some interesting fluorinated $\operatorname{Cr}($ III) alkoxides. It has been shown that $\mathrm{Cr}\left(\mathrm{NEt}_{2}\right)_{3}$ disproportionates easily into $\operatorname{Cr}(I I)$ and $\operatorname{Cr}($ IV) according to the reaction:

III-13 $2 \mathrm{Cr}\left(\mathrm{NEt}_{2}\right)_{3} \rightarrow-\rightarrow \mathrm{Cr}\left(\mathrm{NEt}_{2}\right)_{2}+\mathrm{Cr}\left(\mathrm{NEt}_{2}\right)_{4}$

It is thus possible that similarly, $\operatorname{Cr}(O R)_{3}$ could undergo such disproportionation reaction and yield the $\operatorname{Cr}$ (IV) alkoxide. This posibility has not been investigated.

\section{Recommendation:}

Despite the unsatisfactory results obtained in $\operatorname{Cr}(I V)$ reactions, much information was obtained and it is hoped that future studies will unveil a clearer understanding of the general chemistry of $\mathrm{Cr}$ (IV) derivatives, alkoxides in particular. 
CHAPTER IV

FLUORINATED HYPOCHLORITES

\section{INTRODUCTION.}

Heptafluoro-iso-propyl and perfluoro-t-amyl hypochlorites.

The chemistry of the fluorinated hypochlorites was extended to include the heptafluoroisopropyl hypochlorite, $i-C_{3} F_{7}$ OCl, and the newly made perfluoro-t-amy 1 hypochlorite, $\quad \mathrm{CF}_{3} \mathrm{CF}_{2} \mathrm{C}\left(\mathrm{CF}_{3}\right)_{2} \mathrm{OCl}$. Also, since other fluoroalkyl hypochrorites add to olefins, it was of interest to see whether heptafluoroisopropyl hypochlorite would behave in a similar fashion. The reaction of $\mathrm{i}-\mathrm{C}_{3} \mathrm{~F}_{7} \mathrm{OCl}$ with $\mathrm{CF}_{2}=\mathrm{CF}_{2}$ suggests that it too may have a rich chemistry in preparing new fluorine containing ethers. Thus the reaction of the hypochlorite with selected olefins other than TFE was studied.

In general, reactions were run at low temperatures in order to limit the thermal decomposition of the hypochlorite. Other precautionary measures include shielding from light since light enhances the rate of decomposition of the hypochlorite. The hypochlorite was handled with extreme care as it was found by accident to 
be shock sensitive.

The byproducts, $\left(\mathrm{CF}_{3}\right)_{2} \mathrm{C}=0$ and $\mathrm{CF}_{3} \mathrm{Cl}$ offer an advantage in the reactions performed with the hypochlorite as they were easily removed from the reaction mixture simply by vacuum transfer, thus leaving in many cases, the desired product in good yield. In some cases, the reaction mechanism favors C1F elimination and when this was observed, the desired product was not found.

In reaction with metal and non-metal oxidants, satisfactory results were not obtained. This was attributed to the labile nature of the lone fluorine atom on the alpha-carbon of the hypochlorite. It is presumed that in these reactions, the fluorine migrated easily, leading to the formation of mixed products.

In this study a more extensive series of reactions between polyfluoroalkyl hypochlorites and selected olefins have been carried out. The reaction was found to be quite general for terminal olefins and in most cases, the addition is predominantly unidirectional. The generalized equation below represents the reactions described in this work:

$$
\begin{aligned}
& I V-1 \quad R_{f} \mathrm{OCl}+R^{\prime}-\cdots R_{f} \mathrm{O}-\mathrm{R}^{\prime}-\mathrm{C} 1 \\
& \mathrm{R}_{\mathrm{f}}=\mathrm{i}-\mathrm{C}_{3} \mathrm{~F}_{7}-, \quad \mathrm{R}^{\prime}=\mathrm{SF}_{5} \mathrm{CH}=\mathrm{CH}_{2}, \quad \mathrm{SF}{ }_{5} \mathrm{CH}=\mathrm{CF}_{2}, \quad \mathrm{CH}_{2}=\mathrm{CH}_{2}
\end{aligned}
$$

The results of the addition of $\left(\mathrm{CF}_{3}\right)_{2} \mathrm{CFOC} 1$ to 
olefinic compounds have not been fully investigated. However, for a number of systems, it has been found that $\mathrm{CF}_{3} \mathrm{OCl}$ adds in such a way as to produce only one isomer. For example $\mathrm{CF}_{3} \mathrm{OCl}$ reacted with $\mathrm{CHCl}=\mathrm{CH}_{2}$ to form only $\mathrm{CF}_{3} \mathrm{OCHClCH}_{2} \mathrm{Cl}(44)$. This discounts the possible addition invoking Markonikov's reaction to yield syn products $(44,46)$. In all our compounds, only one isomer was found, the addition being essentially unidirectional with $\mathrm{C} 1$ adding to the least hindered position. It has been found that in some olefinic systems, $\mathrm{COF}_{2}$ elimination occurred either in place of $\mathrm{CF}_{3} \mathrm{OCl}$ addition or with $\mathrm{CF}_{3} \mathrm{OCl}$ addition(44,45,46). A radical mechanism was invoked to rationalize the observation(44). For $\left(\mathrm{CF}_{3}\right)_{2} \mathrm{CFOCl}$ addition, the following radical ion mechanism can be postulated:

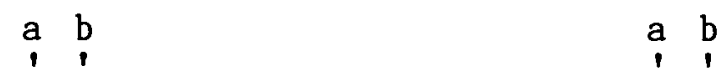

$$
\begin{aligned}
& \mathrm{IV}-2-\mathrm{C}=\mathrm{C}-+\left(\mathrm{CF}_{3}\right)_{2} \mathrm{CFOCl}--->-\mathrm{C}-\mathrm{C}-+\left[\left(\mathrm{CF}_{3}\right)_{2} \mathrm{CFOCl}\right]^{-} \\
& \mathrm{IV}-3 \quad\left[\left(\mathrm{CF}_{3}\right){ }_{2} \mathrm{CFOCl}\right]^{-} \quad \cdots\left[\left(\mathrm{CF}_{3}\right)_{2} \mathrm{CFO}^{\cdot} \mathrm{Cl}^{-}\right]
\end{aligned}
$$

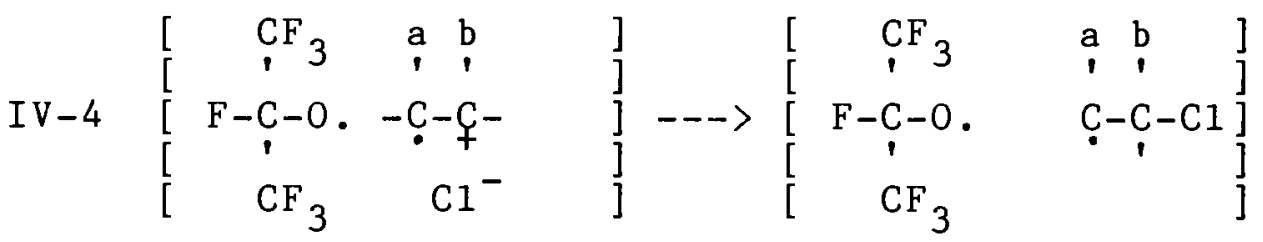

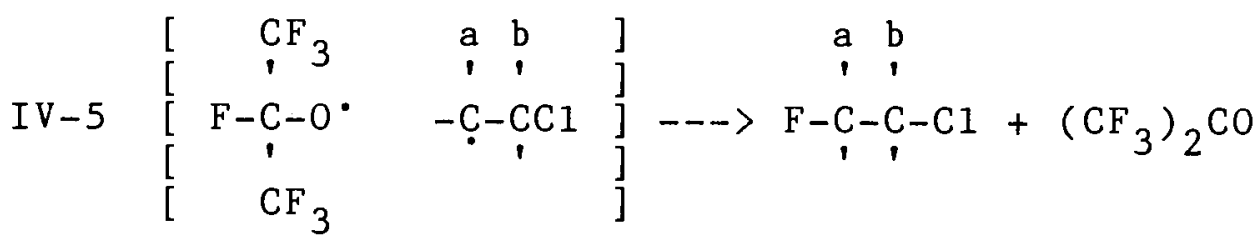




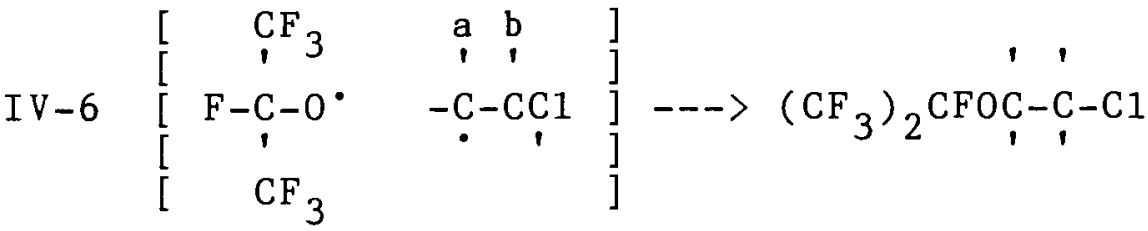

The above mechanism would explain that chlorine attaches to carbon(b) containing the less electronegative substituents whereas carbon(a) with more electronegative substituents adds $F$ via fluorine abstraction or $\left(\mathrm{CF}_{3}\right)_{2} \mathrm{CFO}^{\circ}$ via recombination. In our compounds, abstraction was not observed. It is possible that a second oxidation-reduction step occurs prior to 4 or 5 as shown in eqn(7).

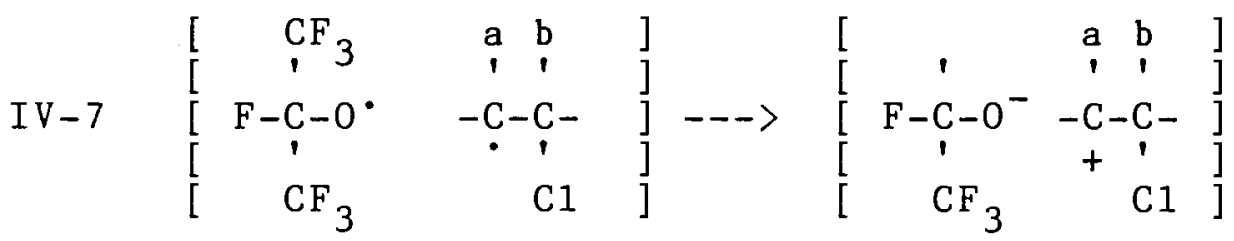

The heptafluoroalkoxide ion could recombine to give the desired ether or undergo $\mathrm{CO}\left(\mathrm{CF}_{3}\right)_{2}$ elimination with the resulting $\mathrm{F}^{-}$adding to the carbocation. It is presumed that unsymetical hydrogen-containing olefins would be more susceptible to $\mathrm{F} / \mathrm{F}^{-}$abstraction with concomitant formation of $\mathrm{CO}\left(\mathrm{CF}_{3}\right)_{2}$ than more symmetrical systems(44).

When $\mathrm{i}-\mathrm{C}_{3} \mathrm{~F}_{7} \mathrm{OCl}$ was reacted with $\mathrm{Hg}$, the product formed was not successfully analyzed but weight comparisons suggested that $\mathrm{HgF}_{2}$ or $\mathrm{HgClF}$ was formed. It was thought that the mercurial, $\mathrm{i}-\mathrm{C}_{3} \mathrm{~F}_{7} \mathrm{OHgCl}$ would be 
formed.

With $I_{2}$, presence of $I_{5}$ was detected and the decomposition products of the hypochlorite; similar reaction with $\left(\mathrm{CF}_{3}\right)_{3} \mathrm{COCl}$ gave $\mathrm{I}\left[\mathrm{OC}\left(\mathrm{CF}_{3}\right)_{3}\right]_{3} \cdot$ Similarly, the reaction with $\mathrm{TiCl}_{4}$ was not satisfactory as the weight changes suggested that fluorination again occurred. The products were not successfully analyzed.

\section{EXPERIMENTAL.}

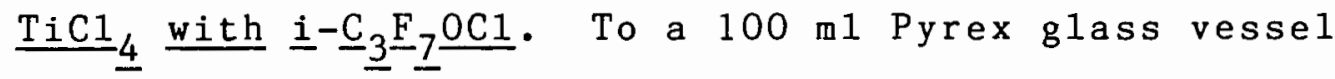
equipped with a Kontes Telfon valve and Teflon stirring bar, was added 0.913 mmole of $\mathrm{TiCl}_{4} \cdot 4.898$ mmole of $i-C_{3} F_{7} O C 1$ was condensed into the reaction vessel at $-196^{\circ} \mathrm{C}$. The vessel was allowed to warm to $0^{\circ} \mathrm{C}$ and kept there for 18 hours. After removing volatile materials in vacuo, $0.2125 \mathrm{~g}$ of an orange solid was obtained. The infrared spectrum of the volatile material showed the presence of $\left(\mathrm{CF}_{3}\right)_{2} \mathrm{CO}$ and $\mathrm{CF}_{3}(\mathrm{O}) \mathrm{F}$. Subsequent addition of excess $\mathrm{i}-\mathrm{C}_{3} \mathrm{~F}_{7} \mathrm{OCl}$ did not improve the product yield. The solid was found to decompose at $232^{\circ} \mathrm{C}$ and was unstable in air. IR spectrum of the orange solid was not conclusive and further studies were not undertaken.

$\underline{I}_{2}$ with $\underline{i}-\underline{C}_{3} \underline{F}_{7} \underline{O C 1}$.

To a 100 m1 Pyrex glass vessel equipped with a Teflon 
Kontes valve and Teflon stirring bar was added 0.4196 mmole of $\mathrm{I}_{2}$, and 7.211 mmole of $\mathrm{i}-\mathrm{C}_{3} \mathrm{~F}_{7} \mathrm{OCl}$ was condensed into the reaction vessel at $-196^{\circ} \mathrm{C}$. The reaction vessel was allowed to warm to $0^{\circ} \mathrm{C}$. by itself. After 4 hours at $0^{\circ} \mathrm{C}$, a white semi solid was formed. The reaction was left to stir at $0^{\circ} \mathrm{C}$ for another 18 hours since some unreacted materials were noticed. After removing volatiles at $-78^{\circ} \mathrm{C}, 0.20 \mathrm{~g}$ white crystalline solid was obtained. The infrared spectrum of the volatile materials showed the presence of $\left(\mathrm{CF}_{3}\right)_{2} \mathrm{C}=0$ and the infrared spectrum of the white solid showed the presence of $\mathrm{IF}_{5}$. Attempt to determine the melting point of the solid was not successfu1.

Hg with $\underline{i}-\underline{C}_{3} \underline{F}_{7} \underline{O C 1}$.

To a $75 \mathrm{ml}$ Pyrex glass vessel equipped with a Teflon Kontes valve and Teflon stirring bar was added 1.480 mmole of $\mathrm{Hg}$. The reaction vessel was pumped on the vacuum line and reweighed to determine the exact weight of the $\mathrm{Hg}$. 2.402 mmole of Freon-11 and 3.080 mmole of $i-C_{3} F_{7} 0 \mathrm{Cl}$ were condensed into the reaction vessel at $-196^{\circ} \mathrm{C}$. The reaction vessel was allowed to attain room temperature slowly and then stirred for 16 hours. Additional 1.820 mmole of $\mathrm{CCl}_{3} \mathrm{~F}$ and 1.950 mmole of $\mathrm{i}-\mathrm{C}_{3} \mathrm{~F}_{7} \mathrm{OCl}$ were condensed into the reaction vessel and then stirred at room temperature for an additional 24 hours. Volatile 
materials were removed at $-78^{\circ} \mathrm{C},-27^{\circ} \mathrm{C}$, and room temperature respectively. The infrared spectrum of the volatiles showed the presence of $\left(\mathrm{CF}_{3}\right)_{2} \mathrm{C}=0$, $\mathrm{CF}_{3} \mathrm{C}(0) \mathrm{F}$ and $\mathrm{CF}_{3} \mathrm{Cl}$. The $0.387 \mathrm{~g}$ white solid obtained did not show the characteristic absorptions of the mercury complex in the C-F region. The weight changes suggest that $\mathrm{HgClF}$ or $\mathrm{HgF}_{2}$ presumably were formed. The solid decomposed at $275^{\circ} \mathrm{C}$, forming a yellow solid. It was insoluble in common organic solvents and easily attacked by air forming a yellow to orange solid.

$\underline{S F}_{5} \underline{\mathrm{CH}}=\underline{\mathrm{CH}}_{2}$ with $\underline{i}-\underline{\mathrm{C}}_{3} \underline{\mathrm{F}}_{7} \underline{\mathrm{OC} 1}$.

To a 75 ml Pyrex glass vessel equipped with a Teflon Kontes valve and Teflon stirring bar was condensed 16.75 mmole of $\mathrm{SF}_{5} \mathrm{CH}=\mathrm{CH}_{2}$ and 21.09 mmole of $\mathrm{i}-\mathrm{C}_{3} \mathrm{~F}_{7} \mathrm{OCl}$ at $-196^{\circ} \mathrm{C}$. The reaction vessel was slowly brought to $0^{\circ} \mathrm{C}$ and stirred for 15 hours. The infrared spectrum of the volatile materials showed the presence of $\mathrm{CF}_{3} \mathrm{COF},\left(\mathrm{CF}_{3}\right)_{2} \mathrm{C}=0$ and $\mathrm{CF}_{3} \mathrm{Cl}$. After removing volatile materials at $-196^{\circ} \mathrm{C}$, the clear liquid was distilled. The fraction boiling at $89-127^{\circ} \mathrm{C}$, and the pot residue were mixed, washed with water, and after drying over $\mathrm{MgSO}_{4}$ for $2 \frac{1}{2}$ hours, were redistilled. The liquid boiling at $124-128^{\circ} \mathrm{C}, 1.20 \mathrm{~g}$, $19.2 \%$ was used for IR, NMR and elemental analysis. Elem. Anal.: Calc. for $\mathrm{SF}_{5} \mathrm{CHClCH}_{2} \mathrm{OCF}\left(\mathrm{CF}_{3}\right)_{2}: \mathrm{S}, 8.60$; 
F,60.86; C,16.00; H,0.81; C1,9.47. Found: S,8.66; $\mathrm{F}, 60.80 ; \mathrm{C}, 15.97 ; \mathrm{H}, 0.82 ; \mathrm{Cl} 1,9.61$.

The ${ }^{19}$ F NMR spectrum for $\mathrm{F}^{\mathrm{a}} \mathrm{SF}_{4}{ }^{\mathrm{b}} \mathrm{CH}^{\mathrm{c}} \mathrm{C} 1 \mathrm{CH}^{\mathrm{d}} \mathrm{H}^{\mathrm{e}} \mathrm{OC}\left(\mathrm{CF}_{3}{ }^{\mathrm{f}}\right)_{2} \mathrm{~F}^{\mathrm{g}}$ contained a doublet at $\varnothing 53.2\left(F^{b}\right)$, a doublet of multiplets at $\varnothing 73.0\left(\mathrm{~F}^{\mathrm{a}}\right)$, a seven-line pattern at $\varnothing-148.5\left(\mathrm{~F}^{\mathrm{g}}\right)$ and a singlet at $\quad \mathcal{f}-83.1\left(\mathrm{~F}^{\mathrm{f}}\right)$, with relative areas of $4.0: 1.0: 1.0: 6.0$ respectively (theor: $4.0: 1.0: 1.0: 6.0$ ) and coupling constants of $J_{f-g}=6.0$ and $J_{a-b}=158 \mathrm{~Hz}$. The ${ }^{1} H$ NMR spectrum contained multiplets at $\hat{\theta} 4.7\left(\mathrm{H}^{\mathrm{d}, \mathrm{e}}\right)$ and $\hat{\ell} 5.6\left(\mathrm{H}^{\mathrm{c}}\right)$ ppm, with relative band areas of $1.8: 1.0$ respectively (theor: 2.0:1.0). The coupling constants are $\mathrm{J}_{\mathrm{c}-\mathrm{d}}=6.2 \mathrm{~Hz}, \mathrm{~J}_{\mathrm{c}-\mathrm{e}}=6.0 \mathrm{~Hz}, \mathrm{~J}_{\mathrm{b}-\mathrm{c}}=5.1 \mathrm{~Hz}$ and $\mathrm{J}_{\mathrm{d}-\mathrm{e}}=6.8 \mathrm{~Hz}$. See Tables $X V$ and $X V I$ respectively.

$\underline{\mathrm{SF}}_{5}-\underline{\mathrm{CH}}=\underline{\mathrm{CF}}_{2}$ with $\underline{i}-\underline{C}_{3} \underline{\mathrm{F}}-\underline{0 \mathrm{OC} 1}$.

To a 100 ml Pyrex glass vessel equipped with a Teflon Kontes valve and Teflon stirring bar was condensed 9.848 mmole of $\mathrm{SF}_{5} \mathrm{CH}=\mathrm{CF}_{2}$ and 12.38 mmole of $\mathrm{i}-\mathrm{C}_{3} \mathrm{~F}_{7} \mathrm{OCl}$ at $-196^{\circ} \mathrm{C}$. The reaction was allowed to warm up to $0^{\circ} \mathrm{C}$ slowly and then stirred at $0^{\circ} \mathrm{C}$ for 16 hours. Additional stirring was done for $3 \frac{1}{2}$ hours at room temperature. The infrared spectrum of the volatile materials showed the presence of $\left(\mathrm{CF}_{3}\right)_{2} \mathrm{CO}, \quad \mathrm{CF}_{3} \mathrm{COF}$, and $\mathrm{CF}_{3} \mathrm{Cl}$. The clear liquid was distilled and the portion boiling at $83^{\circ} \mathrm{C},(1.16 \mathrm{~g}, 28.7 \%)$, was used for IR and NMR studies.

The ${ }^{19} \mathrm{~F}$ NMR spectrum for $\mathrm{F}^{\mathrm{a}} \mathrm{SF}_{4}{ }^{\mathrm{b}} \mathrm{CH}^{\mathrm{c}} \mathrm{C} 1 \mathrm{CF}^{\mathrm{d}} \mathrm{F}^{\mathrm{e}} \mathrm{OC}\left(\mathrm{CF}_{3}{ }^{\mathrm{f}}\right) \mathrm{F}^{\mathrm{g}}$ 
contained multiplets at $\varnothing 71.2\left(\mathrm{~F}^{\mathrm{a}}\right)$ and $\varnothing-147.6\left(\mathrm{~F}^{\mathrm{g}}\right)$ respectively, a doublet at $057.4\left(\mathrm{~F}^{\mathrm{b}}\right)$, and singlets at $\varnothing-82.3\left(\mathrm{~F}^{\mathrm{f}}\right)$ and $\varnothing-71.3\left(\mathrm{~F}^{\mathrm{d}, \mathrm{e}}\right)$ respectively. The relative band areas are 1.0:1.0:3.9:6.5:1.5 (theor: $1.0: 1.0: 4.0: 6.0: 2.0)$ respectively; and the coupling constants are $J_{a-b} 141.1 \mathrm{~Hz}$ and $J_{f-g} 21.2 \mathrm{~Hz}$. The ${ }_{H} \mathrm{H}$ NMR spectrum contained multiplets at $5.82\left(\mathrm{H}^{\mathrm{C}}\right)$ and $\delta 5.53$ $(\mathrm{C}=\mathrm{C}$ ? impurity) respectively and coupling constants of $J_{b-c}=5.4 \mathrm{~Hz}$. See Tables $X V$ and $X V I$ respectively.

$\underline{\mathrm{CH}}_{2}=\underline{\mathrm{CH}}_{2}$ with $\underline{\mathrm{i}}-\underline{\mathrm{C}}_{3} \underline{\mathrm{F}}_{7}-\underline{\mathrm{OC} 1}$.

To a 1000 m1 Pyrex glass vessel equipped with a Teflon valve was condensed 9.982 mmole of $\mathrm{CH}_{2}=\mathrm{CH}_{2}$ and 10.84 mmole $\mathrm{i}-\mathrm{C}_{3} \mathrm{~F}_{7} \mathrm{OC} 1$ at $-196^{\circ} \mathrm{C}$. The reaction vessel was immediately warmed to $0^{\circ} \mathrm{C}$ for 18 hours. Due to the yellow liquid noted, the reaction was presumed incomplete and was stirred at room temperature for an additional 7 hours. The liquid was washed with water, dried over $\mathrm{MgSO}_{4}$ and distilled. The fraction boiling at $79-85^{\circ} \mathrm{C}, 0.81 \mathrm{~g}, 32.7 \%$ was used for IR and NMR studies.

The ${ }^{19} \mathrm{~F}$ NMR spectrum for $\mathrm{ClCH}_{2}{ }^{\mathrm{a}} \mathrm{CH}_{2}{ }^{\mathrm{b}} \mathrm{OC}\left(\mathrm{CF}_{3}{ }^{\mathrm{c}}\right)_{2} \mathrm{~F}^{\mathrm{d}}$ contained a doublet at $\varnothing-82.5\left(\mathrm{~F}^{\mathrm{C}}\right)$ and a multiplet at $\phi-145.2\left(\mathrm{~F}^{\mathrm{d}}\right)$; with relative band areas of $6.0: 1.0$ (theor: $6.0: 1.0)$ respectively, and coupling constant of $\mathrm{J}_{\mathrm{c}-\mathrm{d}} 2.4$ Hz. The ${ }^{1}$ H NMR contained a set of multiplets 
at $\delta 4.4\left(\mathrm{H}^{\mathrm{b}}\right)$ and $\delta 3.9\left(\mathrm{H}^{\mathrm{a}}\right)$ respectively, with relative band areas of $1.0: 1.0$ (theor: $1.0: 1.0$ ) respectively and coupling constant of $\mathrm{J}_{\mathrm{a}-\mathrm{b}}=6.2 \mathrm{~Hz}$. Elem. Anal.: Calc. for $\mathrm{C} 1 C H_{2} \mathrm{CH}_{2} \mathrm{OCF}\left(\mathrm{CF}_{3}\right)_{2} \cdot \mathrm{F}, 54.00 ; \mathrm{C}, 24.16 ; \mathrm{H}, 1.62 ; \mathrm{Cl}, 14.27$. Found: F, 54.20; C, 24.11; H,1.64; C1,14.25.

Preparation of $\underline{\mathrm{CF}}_{3} \underline{\mathrm{CF}}_{2} \underline{\mathrm{C}}\left(\underline{\mathrm{CF}}_{3}\right)_{2} \underline{\mathrm{OH}}$.

To a $100 \mathrm{ml}$ pretreated Monel vessel equipped with two stainless steel ball bearings and Whitey stainless steel valve containing 105.3 mmole of predried CsF was added 25 ml of diethylene glycol dimethyl ether (diglyme) and 122 mmole of hexafluoroacetone was condensed into the reaction vessel at $-196^{\circ} \mathrm{C} . \quad 188.4$ mmole of tetrafluoro ethylene was added in four portions over a four-day period. The reaction vessel was heated at $90-100^{\circ} \mathrm{C}$ for 90 hours with intermittent shaking. After checking for volatile materials at $-130^{\circ} \mathrm{C}$, the reaction vessel was vented in the hood before a clear liquid was extracted with 178 mmole of $96 \% \mathrm{H}_{2} \mathrm{SO}_{4}$ leaving a fluorocarbon residue. The liquid was distilled and the fractions boiling at $65-100^{\circ} \mathrm{C}$ were redistilled in the spinning band equipment. The $8.18 \mathrm{~g}$ (27.3\% yield) clear liquid fraction boiling at $66-67.2^{\circ} \mathrm{C}$ was used for IR and NMR studies.

The ${ }^{19} \mathrm{~F}$ NMR spectrum for $\mathrm{CF}_{3}{ }^{\mathrm{a}} \mathrm{CF}_{2}{ }^{\mathrm{b}} \mathrm{C}\left(\mathrm{CF}_{3}{ }^{\mathrm{c}}\right)_{2} \mathrm{OH}^{\mathrm{d}}$ contained multiplets at $\varnothing-121.8\left(F^{b}\right), \varnothing-82.5\left(F^{a}\right)$ and $\varnothing-75.2\left(\mathrm{~F}^{\mathrm{C}}\right)$ respectively; with relative band areas of 
2.0:3.2:6.2 (theor. 2.0:3.0:6.0) and coupling constants of $J_{a-c}=5.9 \mathrm{~Hz}$ and $J_{b-c}=11.6 \mathrm{~Hz}$. The ${ }^{1} \mathrm{H}$ NMR spectrum contained a singlet at $3.82\left(\mathrm{H}^{\mathrm{d}}\right)$. The infrared spectrum contained the characteristic $0-\mathrm{H}$ stretching frequency at $3627 \mathrm{~cm}^{-1}$. See Table XIV and the appendix for the infrared data and the actual spectrum respectively.

Preparation of $\underline{\mathrm{CF}}_{3} \underline{\mathrm{CF}}_{2} \underline{\mathrm{C}}\left(\underline{\mathrm{CF}}_{3}\right)_{2} \underline{\mathrm{OC} 1}$.

To a $100 \mathrm{ml}$ pretreated Monel vessel equipped with two stainless ball bearings and a Whitey stainless steel valve was condensed 5.00 mmole of $\mathrm{CF}_{3} \mathrm{CF}_{2} \mathrm{C}\left(\mathrm{CF}_{3}\right)_{2} \mathrm{OH}$ and 5.67 mmole of $\mathrm{C} 1 \mathrm{~F}$ at $-196^{\circ} \mathrm{C}$. The reaction vessel was slowly brought up to $0^{\circ} \mathrm{C}$ and kept there for approximately 18 hours. After removing some volatile materials (HF and excess ClF) at $-95^{\circ} \mathrm{C}$, the contents of the vessel were condensed into a second metal reaction vessel containing an excess amount of CsF. This reaction vessel was shaken frequently while slowly warmed to $0^{\circ} \mathrm{C}$. The volatile $\mathrm{CF}_{3} \mathrm{CF}_{2} \mathrm{C}\left(\mathrm{CF}_{3}\right)_{2} \mathrm{OCl}$ was removed from the CsF by pumping on the CsF vessel through a trap cooled to $-196^{\circ} \mathrm{C}$. Prior to this transfer, any volatile material at $-196^{\circ} \mathrm{C}$ in the $\mathrm{CsF}$ vessel was removed. Analysis of the volatile materials showed the presence of HF, CIF and the decomposition products of the hypochlorite - $\left(\mathrm{CF}_{3}\right)_{2} \mathrm{C}=0, \mathrm{CF}_{3} \mathrm{Cl}, \mathrm{CF}_{3} \mathrm{CF}_{2} \mathrm{Cl}$, and $\mathrm{CF}_{3} \mathrm{CF}_{2} \mathrm{COCF}_{3} \cdot 3.59$ mmole ( $72 \%$ yield) of the product was obtained. The sample was 
analyzed through IR and NMR spectra.

The infrared spectrum contained a $C=0$ impurity peak presumably from UV decomposition of the hypochlorite in the gas cell during the infrared operation; see Table XIII and the appendix for infrared data and the actual spectrum respectively.

The ${ }^{19} \mathrm{~F}$ NMR spectrum for $\mathrm{CF}_{3}{ }^{\mathrm{a}} \mathrm{CF}_{2}{ }^{\mathrm{b}} \mathrm{C}\left(\mathrm{CF}_{3}{ }^{\mathrm{c}}\right)_{2} \mathrm{OCl}$ contained multiplets at $\varnothing-115.7, \varnothing-80.4$ and $\varnothing-67.9$ respectively; with relative band areas of 2.0:3.4:6.3 (theor. 2.0:3.0:6.0) and the coupling constants of $J_{a-c}=5.6 \mathrm{~Hz}$ and $J_{b-c}=11.6 \mathrm{~Hz}$.

Elementa1 Analysis for the F-Hypochlorite Compounds.

The elemental analyses of the new fluorinated ethers were carried out by Beller Microanalytisches Laboratorium, Gottingen, West Germany.

Mass Spectral Analysis for the F-Hypochlorite Compounds. The mass spectra of the new fluorinated ethers were obtained at the University of Idaho. In both compounds, $\mathrm{SF}_{5} \mathrm{CHC}_{1 \mathrm{CH}_{2}} \mathrm{OC}_{3} \mathrm{~F}_{7}$ and $\mathrm{ClCH}_{2} \mathrm{CH}_{2} \mathrm{OC}_{3} \mathrm{~F}_{7}$, the mass spectra contained prominent peaks (M/e) at $69\left(\mathrm{CF}_{3}{ }^{+}\right)$and 63 $\left(\mathrm{C}_{2} \mathrm{H}_{4} \mathrm{C} 1^{+}\right)$respectively. None of the compounds exhibited the parent ions in the mass spectra. The mass spectral peaks for these compounds are listed on Table XIII. 
TABLE XIII

MASS SPECTRA DATA FOR F-HYPOCHLORITE COMPOUNDS

$$
\mathrm{ClCH}_{2} \mathrm{CH}_{2} \mathrm{OCF}\left(\mathrm{CF}_{3}\right)_{2}
$$

$\underline{M} / \underline{e}$

42

Re1. Int.

Type

43

0.9

$\mathrm{C}_{2} \mathrm{H}_{2} \mathrm{O}^{+}$

1.5

$\mathrm{CCF}^{+}$

44

1.3

$\mathrm{C}_{2} \mathrm{H}_{4} \mathrm{O}^{+}$

45

0.3

?

46

0.5

?

47

10.7

$\mathrm{CCl}^{+}, \mathrm{CFO}^{+}$

48

0.3

$\mathrm{CHCl}^{+}$

49

5.1

$\mathrm{CH}_{2} \mathrm{Cl}^{+}$

50

1.4

$\mathrm{CF}_{2}{ }^{+}$

51

1.6

$\mathrm{CH}_{2} \mathrm{Cl}^{+}$

52

0.1

$\mathrm{C}_{3} \mathrm{O}^{+}$

55

0.2

$\mathrm{C}_{3} \mathrm{~F}^{+}$

61

1.8

$\mathrm{CH}_{2} \mathrm{CCl}^{+}$

63

100.0

$\mathrm{C}_{2} \mathrm{H}_{4} \mathrm{Cl}^{+}$

64

2.6

$\mathrm{C}_{2} \mathrm{H}_{3} \mathrm{Cl}^{+}$

65

31.0

$\mathrm{C}_{2} \mathrm{H}_{4} \mathrm{Cl}^{+}$

66

0.6

$\mathrm{C}_{4} \mathrm{H}_{2} \mathrm{O}^{+}$ 
$\mathrm{ClCH}_{2} \mathrm{CH}_{2} \mathrm{OCF}\left(\mathrm{CF}_{3}\right)_{2}$ (cont.)

\begin{tabular}{|c|c|c|}
\hline$\underline{M} / \underline{e}$ & Re1. Int. & Type \\
\hline 69 & 32.0 & $\mathrm{CF}_{3}{ }^{+}$ \\
\hline 70 & 0.2 & $?$ \\
\hline 73 & 0.1 & $\mathrm{C}_{3} \mathrm{H}_{2} \mathrm{OF}^{+}$ \\
\hline 78 & 0.2 & $\mathrm{C}_{2} \mathrm{~F}_{2} \mathrm{O}^{+}$ \\
\hline 100 & 1.7 & $\mathrm{C}_{2} \mathrm{~F}_{4}^{+}$ \\
\hline 119 & 3.6 & $\mathrm{C}_{4} \mathrm{HC} \mathrm{HOF}^{+}$ \\
\hline 143 & 0.6 & $\mathrm{C}_{4} \mathrm{H}_{3} \mathrm{~F}_{4} \mathrm{O}^{+}$ \\
\hline 147 & 2.4 & $\mathrm{C}_{3} \mathrm{~F}_{5} \mathrm{O}^{+}$ \\
\hline 149 & 4.3 & $\mathrm{C}_{5} \mathrm{ClF}_{2} \mathrm{O}^{+}$ \\
\hline 150 & 0.8 & $\mathrm{C}_{3} \mathrm{~F}_{6}^{+}$ \\
\hline 169 & 4.8 & $\mathrm{C}_{3} \mathrm{~F}_{7}^{+}$ \\
\hline 179 & 0.9 & $\mathrm{C} \mathrm{CH}_{2} \mathrm{CH}_{2} \mathrm{OC}_{2} \mathrm{~F}_{4}^{+}\left(\mathrm{M}^{+}-\mathrm{CF}_{3}\right)$ \\
\hline 181 & 0.2 & $\mathrm{ClCH}_{2} \mathrm{CH}_{2} \mathrm{OC}_{2} \mathrm{~F}_{4}^{+}$ \\
\hline 185 & 0.3 & $\left(\mathrm{CF}_{3}\right)_{2} \mathrm{OCF}^{+}$ \\
\hline 199 & 34.8 & $\mathrm{CH}_{2} \mathrm{OC}_{3} \mathrm{~F}_{7}^{+}$ \\
\hline 200 & 1.5 & $?$ \\
\hline 212 & 0.5 & $\mathrm{C}_{2} \mathrm{H}_{3} \mathrm{OC}_{3} \mathrm{~F}_{7}^{+}$ \\
\hline 213 & 0.5 & $\mathrm{C}_{2} \mathrm{H}_{4} \mathrm{OC}_{3} \mathrm{~F}_{7}^{+}\left(\mathrm{M}^{+}-\mathrm{Cl}\right)$ \\
\hline
\end{tabular}




\section{$\underline{\mathrm{SF}}_{5} \frac{\mathrm{CHClCH}}{2} \underline{\mathrm{OCF}}\left(\underline{\mathrm{CF}}_{3}\right)_{2}$}

$\underline{M} / \underline{e}$

41

42

43

44

45

46

47

48

49

50

51

52

57

58

59

60

61

62

63

64

65

\begin{abstract}
Re1. Int.
\end{abstract}
0.9

5.8

16.8

7.3

17.8

3.5

0.7

6.1

12.4

7.7

4.7

1.6

0.4

0.2

0.3

1.2

58.0

17.4

18.0

5.8

8.0
Type

$\mathrm{C}_{2} \mathrm{HO}^{+}$

$\mathrm{C}_{2} \mathrm{H}_{2} \mathrm{O}^{+}$

$\mathrm{C}_{2} \mathrm{~F}^{+}$

$\mathrm{CS}^{+}$

$\mathrm{HCS}^{+}$

?

$\mathrm{CFO}^{+}$

$\mathrm{CHCl}^{+}$

$\mathrm{CCl}^{+}$

$\mathrm{CF}_{2}{ }^{+}$

$\mathrm{SF}^{+}$

$\mathrm{C}_{3} \mathrm{O}^{+}$

$\mathrm{C}_{2} \mathrm{SH}^{+}$

$\mathrm{C}_{2} \mathrm{SH}_{2}{ }^{+}$

$\mathrm{C}_{2} \mathrm{Cl}^{+}$

$\mathrm{C}_{2} \mathrm{HCl}^{+}$

$\mathrm{C}_{2} \mathrm{H}_{2} \mathrm{FO}^{+}$

$\mathrm{C}_{2} \mathrm{H}_{3} \mathrm{Cl}^{+}$

$\mathrm{CSF}^{+}$

$\mathrm{C}_{2} \mathrm{H}_{3} \mathrm{Cl}^{+}$

$\mathrm{C}_{4} \mathrm{HO}^{+}$ 


$$
\mathrm{SF}_{5} \mathrm{CHClCH}_{2} \mathrm{OCF}\left(\mathrm{CF}_{3}\right)_{2}(\mathrm{cont} .)
$$

$\underline{M} / \mathrm{e}$

66

67

69

70

71

72

73

75

76

77

78

79

80

83

86

89

90

91

97

98

99
Re1. Int.

0.2

8.4

100.0

5.0

0.1

0.2

1. 2

0.3

1.1

3.1

1.5

1.3

1. 3

72.0

0.4

37.5

0.3

1.6

7.7

0.3

3.6
Type

$\mathrm{C}_{4} \mathrm{H}_{2} \mathrm{O}^{+}$

$\mathrm{C}_{4} \mathrm{H}_{3} \mathrm{O}^{+}$

$\mathrm{CF}_{3}{ }^{+}$

$\mathrm{SF}_{2}{ }^{+}$

$\mathrm{C}_{3} \mathrm{FO}^{+}$

$\mathrm{C}_{3} \mathrm{HFO}^{+}$

$\mathrm{C}_{3} \mathrm{H}_{2} \mathrm{FO}^{+}$

$\mathrm{C}_{2} \mathrm{C} 10^{+}$

$\mathrm{C}_{2} \mathrm{HC}^{+} 0^{+}$

$\mathrm{C}_{2} \mathrm{H}_{2} \mathrm{ClO}^{+}$

$\mathrm{C}_{2} \mathrm{~F}_{2} \mathrm{O}^{+}$

$\mathrm{C}_{2} \mathrm{H}_{2} \mathrm{ClO}^{+}$

$\mathrm{C}_{2} \mathrm{H}_{3} \mathrm{ClO}^{+}$

$\mathrm{C}_{4} \mathrm{OF}^{+}$

$\mathrm{C}_{4} \mathrm{H}_{3} \mathrm{OF}^{+}$

$\mathrm{SF}_{3}{ }^{+}$

$\mathrm{C}_{3} \mathrm{H}_{3} \mathrm{ClO}^{+}$

$\mathrm{C}_{3} \mathrm{~F}_{2} \mathrm{HO}^{+}$

$\mathrm{C}_{4} \mathrm{HSO}^{+}$

$\mathrm{C}_{4} \mathrm{H}_{2} \mathrm{SO}^{+}$

$\mathrm{C}_{4} \mathrm{H}_{3} \mathrm{SO}^{+}$ 


$$
\mathrm{SF}_{5} \mathrm{CHClCH}_{2} \mathrm{OCF}\left(\mathrm{CF}_{3}\right)_{2} \text { (cont.) }
$$

\begin{tabular}{|c|c|c|}
\hline$\underline{M} / \underline{e}$ & Rel. Int. & Type \\
\hline 100 & 4.4 & $\mathrm{C}_{2} \mathrm{~F}_{4}^{+}$ \\
\hline 101 & 1.0 & $\mathrm{SF}_{3} \mathrm{C}^{+}$ \\
\hline 105 & 0.4 & $\mathrm{C}_{3} \mathrm{H}_{2} \mathrm{OSF}^{+}$ \\
\hline 107 & 1.5 & $\mathrm{C}_{2} \mathrm{C}_{150^{+}}$ \\
\hline 108 & 0.6 & $\mathrm{SF}_{4}^{+}$ \\
\hline 109 & 1.1 & $\mathrm{C}_{5} \mathrm{HSO}^{+}$ \\
\hline 111 & 0.5 & $\mathrm{C}_{3} \mathrm{H}_{2} \mathrm{~F}_{3} \mathrm{O}^{+}$ \\
\hline 113 & 0.2 & $\mathrm{SF}_{3} \mathrm{C}_{2}^{+}$ \\
\hline 119 & 13.7 & $\mathrm{C}_{4} \mathrm{HClFO}^{+}$ \\
\hline 120 & 0.4 & $\mathrm{SF}_{4} \mathrm{C}^{+}$ \\
\hline 121 & 0.4 & $\mathrm{SF}_{4} \mathrm{CH}^{+}$ \\
\hline 127 & 16.8 & $\mathrm{SF}_{5}^{+}$ \\
\hline 128 & 0.5 & $\mathrm{C}_{3} \mathrm{~F}_{4} \mathrm{O}^{+}$ \\
\hline 129 & 0.9 & $\mathrm{C}_{3} \mathrm{HF}_{4} \mathrm{O}^{+}$ \\
\hline 131 & 4.1 & $\mathrm{C}_{3} \mathrm{~F}_{5}^{+}$ \\
\hline 132 & 0.2 & $\mathrm{C}_{4} \mathrm{HClOS}^{+}$ \\
\hline 133 & 1.4 & $\mathrm{C}_{4}{ }_{2}{ }_{2} \mathrm{ClOS}^{+}$ \\
\hline 135 & 0.3 & $\mathrm{SF}_{4} \mathrm{C}_{2} \mathrm{H}_{3}{ }^{+}$ \\
\hline
\end{tabular}


$\mathrm{SF}_{5} \mathrm{CHClCH}_{2} \mathrm{OCF}\left(\mathrm{CF}_{3}\right)_{2}$ (cont.)

\begin{tabular}{|c|c|c|}
\hline$\underline{M} / \underline{e}$ & Re1. Int. & Type \\
\hline 141 & 1.1 & $\mathrm{C}_{4} \mathrm{HF}_{4} \mathrm{O}^{+}$ \\
\hline 143 & 1.2 & $\mathrm{C}_{4} \mathrm{H}_{3} \mathrm{~F}_{4} \mathrm{O}^{+}$ \\
\hline 145 & 0.3 & $\mathrm{C}_{5} \mathrm{H}_{2} \mathrm{C}_{1 \mathrm{SO}^{+}}$ \\
\hline 147 & 5.6 & $\mathrm{C}_{3} \mathrm{~F}_{5} \mathrm{O}^{+}$ \\
\hline 148 & 0.2 & $\mathrm{SF}_{3} \mathrm{C}_{2} \mathrm{Cl}^{+}$ \\
\hline 149 & 10.0 & $\mathrm{SF}_{3} \mathrm{C}_{2} \mathrm{HCl}^{+}$ \\
\hline 150 & 1.7 & $\mathrm{C}_{3} \mathrm{~F}_{6}^{+}$ \\
\hline 151 & 0.3 & $\mathrm{SF}_{4} \mathrm{C}_{2} \mathrm{H}_{3} \mathrm{O}^{+}$ \\
\hline 156 & 15.4 & $\mathrm{SF}_{4} \mathrm{CHCl}^{+}$ \\
\hline 157 & 0.7 & $\mathrm{C}_{4} \mathrm{HC} \mathrm{F}_{3} \mathrm{O}^{+}$ \\
\hline 160 & 0.3 & $\mathrm{SF}_{4} \mathrm{C}_{3} \mathrm{O}^{+}$ \\
\hline 161 & 0.9 & $\mathrm{SF}_{4} \mathrm{C}_{3} \mathrm{HO}^{+}$ \\
\hline 163 & 0.2 & $\mathrm{SF}_{4} \mathrm{C}_{3} \mathrm{H}_{3} \mathrm{O}^{+}$ \\
\hline 170 & 0.6 & $\mathrm{C}_{4} \mathrm{HSF}_{2} \mathrm{OCl}^{+}$ \\
\hline 177 & 1.9 & $\mathrm{C}_{4} \mathrm{H}_{2} \mathrm{C} \mathrm{F}_{4} \mathrm{O}^{+}$ \\
\hline 179 & 0.7 & $\mathrm{C}_{4} \mathrm{H}_{2} \mathrm{C} \mathrm{F}_{4} \mathrm{O}^{+}$ \\
\hline 185 & 1.2 & $\left(\mathrm{CF}_{3}\right)_{2} \mathrm{OCF}^{+}$ \\
\hline 187 & 0.3 & $\mathrm{SF}_{5} \mathrm{C}_{2} \mathrm{HCl}^{+}$ \\
\hline 188 & 0.1 & $\mathrm{SF}_{5} \mathrm{C}_{2} \mathrm{H}_{2} \mathrm{Cl}^{+}$ \\
\hline 189 & 23.0 & $\mathrm{SF}_{5} \mathrm{CHClCH}_{2}{ }^{+}$ \\
\hline
\end{tabular}




$$
\mathrm{SF}_{5} \mathrm{CHClCH}_{2} \mathrm{OCF}\left(\mathrm{CF}_{3}\right)_{2} \text { (cont.) }
$$

\section{$\underline{M} / \underline{e}$}

190

191

199

200

201

207

213

217

230

246

247

248

249

250

265

281

282

283

355
Re1. Int.

0.7

8.3

93.0

4.3

0.3

0.8

0.2

0.2

0.4

2. 2

24.0

1.9

7.8

0.5

0.1

1.9

0.6

0.4

0.3

\section{Type}

$\mathrm{SF}_{3} \mathrm{C}_{4} \mathrm{H}_{2} \mathrm{C}_{10}+$

$\mathrm{SF}_{5} \mathrm{CHClCH}_{2}^{+}$

$\mathrm{CH}_{2} \mathrm{OC}_{3} \mathrm{~F}_{7}^{+}$

$\mathrm{SF}_{3} \mathrm{C}_{5} \mathrm{C}_{10}+$

$\mathrm{SF}_{3} \mathrm{C}_{5} \mathrm{HClO}^{+}$

$\mathrm{SF}_{5} \mathrm{C}_{2} \mathrm{H}_{3} \mathrm{C}_{10}+$

$\mathrm{SF}_{3} \mathrm{C}_{4} \mathrm{H}_{3} \mathrm{OF}_{3}+$

$\mathrm{SF}_{5} \mathrm{C}_{3} \mathrm{H}_{3} \mathrm{ClO}^{+}$

$\mathrm{C}_{5} \mathrm{~F}_{7} \mathrm{Cl}^{+}$

$\mathrm{C}_{2} \mathrm{H}_{2} \mathrm{ClOC}_{3} \mathrm{~F}_{7}^{+}$

$\mathrm{C}_{2} \mathrm{H}_{2} \mathrm{ClHOC}_{3} \mathrm{~F}_{7}^{+}\left(\mathrm{M}^{+}-\mathrm{SF}_{5}\right)$

$\mathrm{SF}_{3} \mathrm{C}_{4} \mathrm{H}_{3} \mathrm{C} \mathrm{F}_{3} \mathrm{O}^{+}$

$\mathrm{C}_{2} \mathrm{H}_{2} \mathrm{ClHOC}_{3} \mathrm{~F}_{7}^{+}$

$\mathrm{SF}_{5} \mathrm{C}_{4} \mathrm{H}_{2} \mathrm{~F}_{3} \mathrm{O}^{+}$

$\mathrm{SF}_{4} \mathrm{C}_{4} \mathrm{HC} \mathrm{F}_{3} \mathrm{O}^{+}$

$\mathrm{SF}_{5} \mathrm{C}_{2} \mathrm{H}_{2} \mathrm{OC}_{3} \mathrm{~F}_{4}^{+}$

$\mathrm{SF}_{5} \mathrm{C}_{2} \mathrm{H}_{3} \mathrm{OC}_{3} \mathrm{~F}_{4}^{+}$

$\mathrm{SF}_{5} \mathrm{C}_{3} \mathrm{ClOCF}_{3}{ }^{+}$

$\mathrm{SF}_{5} \mathrm{CHClCH}_{2} \mathrm{OC}_{3} \mathrm{~F}_{6}{ }^{+}\left(\mathrm{M}^{+}-\mathrm{F}\right)$ 
The infrared absorptions for the new hypochlorite complexes are tabulated in Table XIV and the actual spectra are shown in the appendix.

For the compounds, $\mathrm{SF}_{5} \mathrm{CHClCH}_{2} \mathrm{OCF}\left(\mathrm{CF}_{3}\right)_{2}$ and $\mathrm{SF}_{5} \mathrm{CHClCF}_{2} \mathrm{OCF}\left(\mathrm{CF}_{3}\right)_{2}$, the common feature is the $\mathrm{SF}_{5}$ - group which absorbs strongly in the $850-920 \mathrm{~cm}^{-1}$ region for the $S-F$ stretching vibrations and in the $600 \mathrm{~cm}^{-1}$ region for the S-F deformation modes(47). Thus the bands at 835-906 $\mathrm{cm}^{-1}$ observed for $\mathrm{SF}_{5} \mathrm{CHClCF}_{2} \mathrm{OCF}\left(\mathrm{CF}_{3}\right)_{2}$ and $855 \mathrm{~cm}^{-1}$ observed for $\mathrm{SF}_{5} \mathrm{CHClCH}{ }_{2} \mathrm{OCF}\left(\mathrm{CF}_{3}\right)_{2}$ complexes were assigned to the S-F stretching modes. The S-F deformation modes are at 603 and $598 \mathrm{~cm}^{-1}$ respectively for the ether complexes. For all the isopropyl hypochlorite complexes, the $\left(\mathrm{CF}_{3}\right)_{2} \mathrm{CFO}$ showed strong absorption bands in the 1145-1305 $\mathrm{cm}^{-1}$ region are attributable to $\mathrm{C}-\mathrm{F}$ stretching frequency $(49,50)$. Similarly absorption bands at 720-760 $\mathrm{cm}^{-1}$ attributable to $\mathrm{C}-\mathrm{F}$ deformation modes were observed(50). In all of the isopropyl hypochlorite compounds, and the perfluoro-t-amyl group, the absorptions observed at 1110 to $1334 \mathrm{~cm}^{-1}$ and 1124 to $1342 \mathrm{~cm}^{-1}$ respectively, are attributable to C-F stretching frequencies. Also the bands at 723 to $765 \mathrm{~cm}^{-1}$ for the isopropyl hypochlorite complexes and 716 to $765 \mathrm{~cm}^{-1}$ for the perfluoro-t-amyl group are assigned to the C-F deformation modes. The absorptions at 970 to $1096 \mathrm{~cm}^{-1}$ 


\section{TABLE XIV}

INFRARED ABSORPTION BANDS FOR F-HYPOCHLORITES

$$
\left(\mathrm{cm}^{-1}\right) * *
$$

$\mathrm{TiCl}_{4}$ with $\mathrm{i}-\mathrm{C}_{3} \mathrm{~F}_{7} \mathrm{OCl}$

$$
\begin{aligned}
& 1725(\mathrm{mw}), 1772(\mathrm{mw}), \\
& 1334(\mathrm{~m}), 1300(\mathrm{w}), \\
& 1263(\mathrm{w}, \mathrm{sh}), 1228(\mathrm{~m}, \mathrm{sh}), \\
& 1205(\mathrm{~s}), 1091(\mathrm{~m}), 970(\mathrm{~s}), \\
& 735(\mathrm{vs}, \mathrm{b}), 521(\mathrm{vs}, \mathrm{b})
\end{aligned}
$$

$\mathrm{I}_{2}$ with $\mathrm{i}-\mathrm{C}_{3} \mathrm{~F}_{7} \mathrm{OCl}$

$$
\begin{aligned}
& 1897(\mathrm{~ms}), 1454(\mathrm{w}, \mathrm{b}), \\
& 1342(\mathrm{~m}), 1216(\mathrm{vs}), \\
& 1110(\mathrm{vs}), 1025(\mathrm{w}), \\
& 969(\mathrm{mw}), 831(\mathrm{w}), 772(\mathrm{~m}), \\
& 751(\mathrm{w}), 737(\mathrm{~ms}), 701(\mathrm{w}), \\
& 698(\mathrm{mw})
\end{aligned}
$$

$\mathrm{Hg}$ with $\mathrm{i}-\mathrm{C}_{3} \mathrm{~F}_{7} \mathrm{OCl}$

$$
\begin{aligned}
& 1834(\mathrm{w}), 1447(\mathrm{~s}, \mathrm{~b}), \\
& 1229(\mathrm{vs}), 1187(\mathrm{vw}), \\
& 730(\mathrm{w}, \mathrm{b}) \text {. }
\end{aligned}
$$

$\mathrm{SF}_{5} \mathrm{CH}=\mathrm{CH}_{2}$ with i-C $\mathrm{F}_{7} \mathrm{OCl}$

$$
\begin{aligned}
& 2881(\mathrm{vw}), 1329(\mathrm{vw}), \\
& 1299(\mathrm{~m}), 1240(\mathrm{~s}), \\
& 1183(\mathrm{~s}), 1121(\mathrm{~m}), \\
& 1002(\mathrm{~m}), 980(\mathrm{~m}), \\
& 855(\mathrm{vs}), 756(\mathrm{w}), 733(\mathrm{mw}), \\
& 724(\mathrm{mw}), 653(\mathrm{w}), 598(\mathrm{mw}), \\
& 422(\mathrm{~m}) .
\end{aligned}
$$

* m memedium, s=strong, vs=very strong, sh=shoulder, $w=w e a k$, ms=medium strong, mw=medium weak, b=broad. 
TABLE XIV (cont.)

$\mathrm{SF}_{5} \mathrm{CH}=\mathrm{CF}_{2}$ with $i-\mathrm{C}_{3} \mathrm{~F}_{7} \mathrm{OCl}$

$$
\begin{aligned}
& 3107(\mathrm{~m}, \mathrm{~b}), 3008(\mathrm{vw}), \\
& 1314(\mathrm{~m}), 1250(\mathrm{vw}), \\
& 1173(\mathrm{~s}), 1138(\mathrm{~s}), \\
& 1096(\mathrm{~m}), 990(\mathrm{~s}), \\
& 871(\mathrm{~s}), 835(\mathrm{~m}), 758(\mathrm{w}), \\
& 723(\mathrm{~s}), 674(\mathrm{~m}), 639(\mathrm{w}), \\
& 603(\mathrm{~ms}), 575(\mathrm{w}), 540(\mathrm{w}) .
\end{aligned}
$$

$\mathrm{CH}_{2}=\mathrm{CH}_{2}$ with i-C $\mathrm{F}_{7} \mathrm{OCl}$

$$
\begin{aligned}
& 2973(\mathrm{vw}), 1461(\mathrm{vw}), \\
& 1433(\mathrm{vw}), 1328(\mathrm{~ms}), \\
& 1236(\mathrm{~s}), 1180(\mathrm{~s}), \\
& 1110(\mathrm{~ms}), 1011(\mathrm{~s}), \\
& 997(\mathrm{w}, \mathrm{sh}), 765(\mathrm{vw}), \\
& 730(\mathrm{~s}), 688(\mathrm{mw}), 674(\mathrm{mw}), \\
& 548(\mathrm{w}), 533(\mathrm{w}), 477(\mathrm{vw}) .
\end{aligned}
$$

$\mathrm{CF}_{3} \mathrm{CF}_{2} \mathrm{C}\left(\mathrm{CF}_{3}\right)_{2} \mathrm{OH}$

$$
\begin{aligned}
& 3627(\mathrm{~s}), 1342(\mathrm{~m}), 1300(\mathrm{~s}), \\
& 1138(\mathrm{~s}), 1075(\mathrm{~s}), 970(\mathrm{~s}), \\
& 927(\mathrm{w}), 878(\mathrm{~s}), 738(\mathrm{~s}), \\
& 716(\mathrm{~s}) .
\end{aligned}
$$

$\mathrm{CF}_{3} \mathrm{CF}_{2} \mathrm{C}\left(\mathrm{CF}_{3}\right)_{2} \mathrm{OC1}$

$$
\begin{aligned}
& 1342(\mathrm{~s}), 1243(\mathrm{vs}, \mathrm{b}), \\
& 1166(\mathrm{w}), 1124(\mathrm{vs}), 997(\mathrm{w}, \mathrm{sh}), \\
& 976(\mathrm{vs}), 885(\mathrm{mw}), 786(\mathrm{w}), \\
& 765(\mathrm{mw}), 723(\mathrm{~m}), 646(\mathrm{w}), \\
& 533(\mathrm{vw}) .
\end{aligned}
$$


are attributed to the $\mathrm{C}-0$ stretching frequencies observed around $1000 \mathrm{~cm}^{-1}(50)$.

The metal oxygen (M-0) stretching is generally observed below $650 \mathrm{~cm}^{-1}(48)$ and are assigned to peaks found in all the compounds below $653 \mathrm{~cm}^{-1}$. For $\mathrm{SF}_{5} \mathrm{CHClCF}_{2} \mathrm{OCF}\left(\mathrm{CF}_{3}\right)_{2}$, $\mathrm{SF}_{5} \mathrm{CHClCH}_{2} \mathrm{OCF}\left(\mathrm{CF}_{3}\right)_{2}$ and $\mathrm{ClCH}_{2} \mathrm{CH}_{2} \mathrm{OCF}\left(\mathrm{CF}_{3}\right)_{2}$ compounds, the absorptions at 2850 to $2973 \mathrm{~cm}^{-1}$ are attributable to the $\mathrm{C}-\mathrm{H}$ stretching

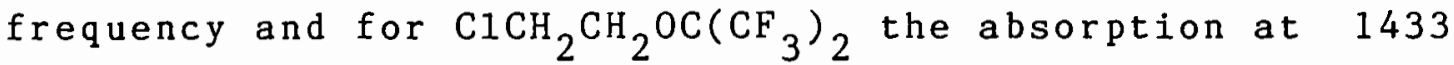
$\mathrm{cm}^{-1}$ is assigned to a $\mathrm{CH}_{2}$ deformation mode(39). For the $\mathrm{CF}_{3} \mathrm{CF}_{2} \mathrm{C}\left(\mathrm{CF}_{3}\right)_{2} \mathrm{OH}$, the absorption at $3627 \mathrm{~cm}^{-1}$ is assigned to $0-\mathrm{H}$ frequency usually observed at $3600-3650 \mathrm{~cm}^{-1}(39)$.

Results and discussion.

The use of the ${ }^{19} \mathrm{~F}$ nmr and ${ }^{1} \mathrm{H}$ nmr spectra have helped us to accurately establish the proposed structures of the new ether complexes. The infrared spectra also gave some structural confirmation for these new compounds. In the discussions of the nmr spectra, comparisons are made with known compounds in terms of their chemical shifts, and the coupling constants.

Nuclear Magnetic Resonance specta. Both fluorine and proton, nmr spectra were obtained for the new compounds: $\mathrm{FSF}_{4} \mathrm{CHClCH}_{2} \mathrm{OC}\left(\mathrm{CF}_{3}\right)_{2} \mathrm{~F}$, $\mathrm{FSF}_{4} \mathrm{CHClCF}_{2} \mathrm{OC}\left(\mathrm{CF}_{3}\right)_{2} \mathrm{~F}$, $\mathrm{ClCH}_{2} \mathrm{CH}_{2} \mathrm{OC}\left(\mathrm{CF}_{3}\right)_{2} \mathrm{~F}$. Also reported is the fluorine nmr 
spectrum for $\mathrm{CF}_{3} \mathrm{CF}_{2} \mathrm{C}\left(\mathrm{CF}_{3}\right)_{2} \mathrm{OCl}$. The ${ }^{19} \mathrm{~F}$ nmr shifts are expressed in parts per million relative to Freon-11; for the $1_{H}$ nmr spectra, chemical shifts to TMS external standard.

The chemical shifts, and also the nmr coupling constants are listed in Tables XV and XVI respectively. The spectra are generally complex, and this may be attributed to the fluorine splitting of protons and the asymmetric nature of the compounds. There is relatively little nmr data available for similar compounds; as a result, not all of the coupling constants could be determined; however, enough information was presented to confirm the structures of the new compounds as presented in the table.

In $\mathrm{SF}_{5}$-containing fluoro ethers, the nmr pattern for the $\mathrm{SF}_{5}$ group consisted of the expected $\mathrm{AB}_{4}$ pattern with $\mathrm{B}_{4}$ equatorial fluorine atoms split into a doublet and the A part split into a multiplet pattern. Analysis of the chemical shifts confirmed the proposed structures. For example, the proton chemical shifts of a CHX group next to an $\mathrm{SF}_{5}$ group is consistent from one $\mathrm{SF}_{5}$-fluoroalkyl derivative to another(44). In our compounds, the proton chemical shift values for $\mathrm{FSF}_{4} \mathrm{CHClCH}_{2} \mathrm{OC}\left(\mathrm{CF}_{3}\right) \mathrm{F}$ and $\mathrm{FSF}_{4} \mathrm{CHClCF}_{2} \mathrm{OC}\left(\mathrm{CF}_{3}\right)_{2} \mathrm{~F}$ were $\delta 5.58$ and $\delta 5.82$ ppm respectively; the coupling constants were: $J_{f-g}=6.0 H z$ and 
$21.2 \mathrm{~Hz}, \mathrm{~J}_{\mathrm{a}-\mathrm{b}}=158 \mathrm{~Hz}$ and $141.1 \mathrm{~Hz}$ respectively for the ${ }^{19} \mathrm{~F}$ nmr. For other $\mathrm{SF}_{5}$ systems, such as $\mathrm{SF}_{5} \mathrm{CHFCFC1Br}$, and $\mathrm{SF}_{5}-\mathrm{CHClCF}_{2} \mathrm{Br}$, the ${ }^{1} \mathrm{H}$ NMR values were, $\delta 5.41, \delta 5.58$, $\delta 5.85, \delta 5.68$, and $\delta 5.50$ ppm respectively(44); and the $\mathrm{J}_{\mathrm{a}-\mathrm{b}}$ for $\mathrm{F}^{\mathrm{a}} \mathrm{SF}_{4}{ }^{\mathrm{b}} \mathrm{CHClCH}_{2} \mathrm{OCF}_{3}$, $\quad \mathrm{F}^{\mathrm{a}} \mathrm{SF}_{4}{ }^{\mathrm{b}} \mathrm{CFClCF}_{2} \mathrm{OCF}_{3}$, $\mathrm{F}^{\mathrm{a}} \mathrm{SF}_{4}{ }^{\mathrm{b}} \mathrm{OCH}_{2} \mathrm{CH}_{2} \mathrm{Cl}$ and $\mathrm{F}^{\mathrm{a}} \mathrm{SF}_{4}{ }^{\mathrm{b}} \mathrm{OCFCF}_{2} \mathrm{Cl}$ were $144,143,146$, and $153.6 \mathrm{~Hz}$ respectively(44). Also for the compounds $\mathrm{SF}_{5} \mathrm{CHClCH}_{2} \mathrm{OCF}_{3}$, $\mathrm{SF}_{5} \mathrm{CHClCF}_{3}$, and $\mathrm{SF}_{5} \mathrm{CHClCF}_{2} \mathrm{Cl}$, the $\mathrm{CHX}$ proton chemical shifts were found to be $\delta 5.62,5.61,6.10$ ppm, respectively(44). For the $1_{H}$ nmr, the coupling constants for the following compounds were found: $\mathrm{F}^{\mathrm{a}} \mathrm{SF}_{4}{ }^{\mathrm{b}} \mathrm{CH}^{\mathrm{C}} \mathrm{ClCH}^{\mathrm{d}} \mathrm{H}^{\mathrm{e}} \mathrm{OC}\left(\mathrm{CF}_{3}{ }^{\mathrm{f}}\right)_{2} \mathrm{~F}^{\mathrm{g}}, \mathrm{J}_{\mathrm{b}-\mathrm{c}}=5.1 \mathrm{~Hz}, \mathrm{~J}_{\mathrm{c}-\mathrm{e}}=6.0$ $\mathrm{Hz}$; for $\mathrm{F}^{\mathrm{a}} \mathrm{SF}_{4}{ }^{\mathrm{b}} \mathrm{CH}^{\mathrm{c}} \mathrm{ClCF} \mathrm{F}^{\mathrm{d}} \mathrm{OC}\left(\mathrm{CF}_{3}{ }^{f}\right)_{2} \mathrm{~F}^{\mathrm{g}}$, we found $\mathrm{J}_{\mathrm{b}-\mathrm{c}}=5.4 \mathrm{~Hz}$ and for $\mathrm{ClCH}_{2}{ }^{\mathrm{a}} \mathrm{CH}_{2}{ }^{\mathrm{b}} \mathrm{OC}\left(\mathrm{CF}_{3}\right)_{2} \mathrm{~F}$ we found $\mathrm{J}_{\mathrm{a}-\mathrm{b}}=6.2 \mathrm{~Hz}$. In other compounds, e.g. $\quad \mathrm{F}^{\mathrm{a}} \mathrm{SF}_{4}{ }^{\mathrm{b}} \mathrm{CH}^{\mathrm{c}} \mathrm{ClCH}^{\mathrm{d}} \mathrm{H}^{\mathrm{e}} \mathrm{OCF}_{3}$, the ${ }^{1} \mathrm{H} \mathrm{nmr}$ coupling constants were $J_{b-c}=4.5 \mathrm{~Hz}$, and $J_{c-e}=6.9 \mathrm{~Hz}(44)$, for $\mathrm{F}^{\mathrm{a}} \mathrm{SF}_{4}{ }^{\mathrm{b}} \mathrm{OCH}_{2}{ }^{\mathrm{c}} \mathrm{CH}_{2}{ }^{\mathrm{d}} \mathrm{Cl}, \quad \mathrm{J}_{\mathrm{c}-\mathrm{d}}=6.2 \quad \mathrm{~Hz}$ and for $\quad \mathrm{ClCH}_{2}{ }^{\mathrm{a}} \mathrm{CH}_{2}{ }^{\mathrm{b}} \mathrm{OC}\left(\mathrm{CF}_{3}\right)_{2} \mathrm{~F}, \mathrm{~J}_{\mathrm{a}-\mathrm{b}}=6.0 \mathrm{~Hz}$.

The ${ }^{19} \mathrm{~F}$ nmr chemical shifts of the $\mathrm{FSF}_{4}$ group of our compounds were comparable to known values; for $\mathrm{FSF}_{4} \mathrm{CHClCH}_{2} \mathrm{OC}\left(\mathrm{CF}_{3}\right)_{2} \mathrm{~F}$, and $\mathrm{FSF}_{4} \mathrm{CHClCF}_{2} \mathrm{OC}\left(\mathrm{CF}_{3}\right)_{2} \mathrm{~F}$, the $\mathrm{SF}$ ax chemical shifts were $\varnothing 73.0$ and $\varnothing 71.2$ and the $\mathrm{SF}_{4(\mathrm{eq})}$ were $\oint 53.2$ and $\oint 57.4$ ppm respectively. In $\mathrm{FSF}_{4} \mathrm{CHClCH}_{2} \mathrm{OCF}_{3}, \mathrm{FSF}_{4} \mathrm{CFClCF}_{2} \mathrm{OCF}_{3}$, and $\mathrm{FSF}_{4} \mathrm{OCH}_{2} \mathrm{CH}_{2} \mathrm{Cl}$, the chemical shift values were $\oint 73.3, \oint 63.3, \phi 74.9 \mathrm{ppm}$ 
for the SF (ax) and $\varnothing 53.2, \emptyset 46.3$ and $\emptyset 59.8 \mathrm{ppm}$ for the $\mathrm{SF}_{4(\mathrm{eq})}$ respectively $(29,44)$. W. B. Fox et a1.(29) found that for impure $\left(\mathrm{CF}_{3}\right)_{2} \mathrm{CFOCF}_{2} \mathrm{CF}_{2} \mathrm{Cl}$, the $-\mathrm{C}\left(\mathrm{CF}_{3}\right)_{2}-$ chemical shift has a triplet of doublets at $\varnothing-80.3$ and for -CF-, a complex triplet at $\varnothing-143.1 \mathrm{ppm}(29)$. In our $\left(\mathrm{CF}_{3}\right)_{2} \mathrm{CFOCH}_{2} \mathrm{CH}_{2} \mathrm{Cl}$, the $-\mathrm{C}\left(\mathrm{CF}_{3}\right)_{2}-$ group was found to be a doublet at $\varnothing-82.5$ and for the $-C F-$ group a multiplet at $\varnothing-145.2$ ppm, respectively. For the perfluoro-t-amyl hypochlorite, $\mathrm{CF}_{3} \mathrm{CF}_{2} \mathrm{C}\left(\mathrm{CF}_{3}\right)_{2} \mathrm{OCl}$, the chemical shifts, and also the nmr coupling constants are listed on Tables $X V$ and XVI respectively. Analysis of the ${ }^{19}$ F NMR chemical shifts referenced to the parent alcohol chemical shifts, confirmed the proposed structure of the new hypochlorite. Graham and Weinmayr(30) found, for the perfluoro-t-amyl alcohol, $\mathrm{CF}_{3} \mathrm{CF}_{2} \mathrm{C}\left(\mathrm{CF}_{3}\right)_{2} \mathrm{OH}$, the following chemical shifts: $\varnothing-80.63\left(\mathrm{~F}^{\mathrm{a}}\right), \phi-73.18\left(\mathrm{~F}^{\mathrm{c}}\right)$ and $\oint-119.28\left(\mathrm{~F}^{\mathrm{b}}\right)$ respectively; with relative areas of 3,2 , and 6(30). For our alcohol, we found the chemical shifts of these groups at $\phi-82.5, \phi-75.2$, and $\phi-121.8$ respectively with relative band areas of $3.2,2.0$, and 6.2 respectively. We also found, in the ${ }^{1}$ H NMR spectrum, a chemical shift of 3.8 for the $\mathrm{OH}$. From the ${ }^{19} \mathrm{~F}$ NMR spectrum, we obtained the following coupling constants: $\mathrm{J}_{\mathrm{b}-\mathrm{c}}=11.5 \mathrm{~Hz}$ and $\mathrm{J}_{\mathrm{a}-\mathrm{c}}=5.8 \mathrm{~Hz}$. The ${ }^{19} \mathrm{~F}$ NMR chemical shift of our new perfluoro-t-amyl hypochlorite was compared to 


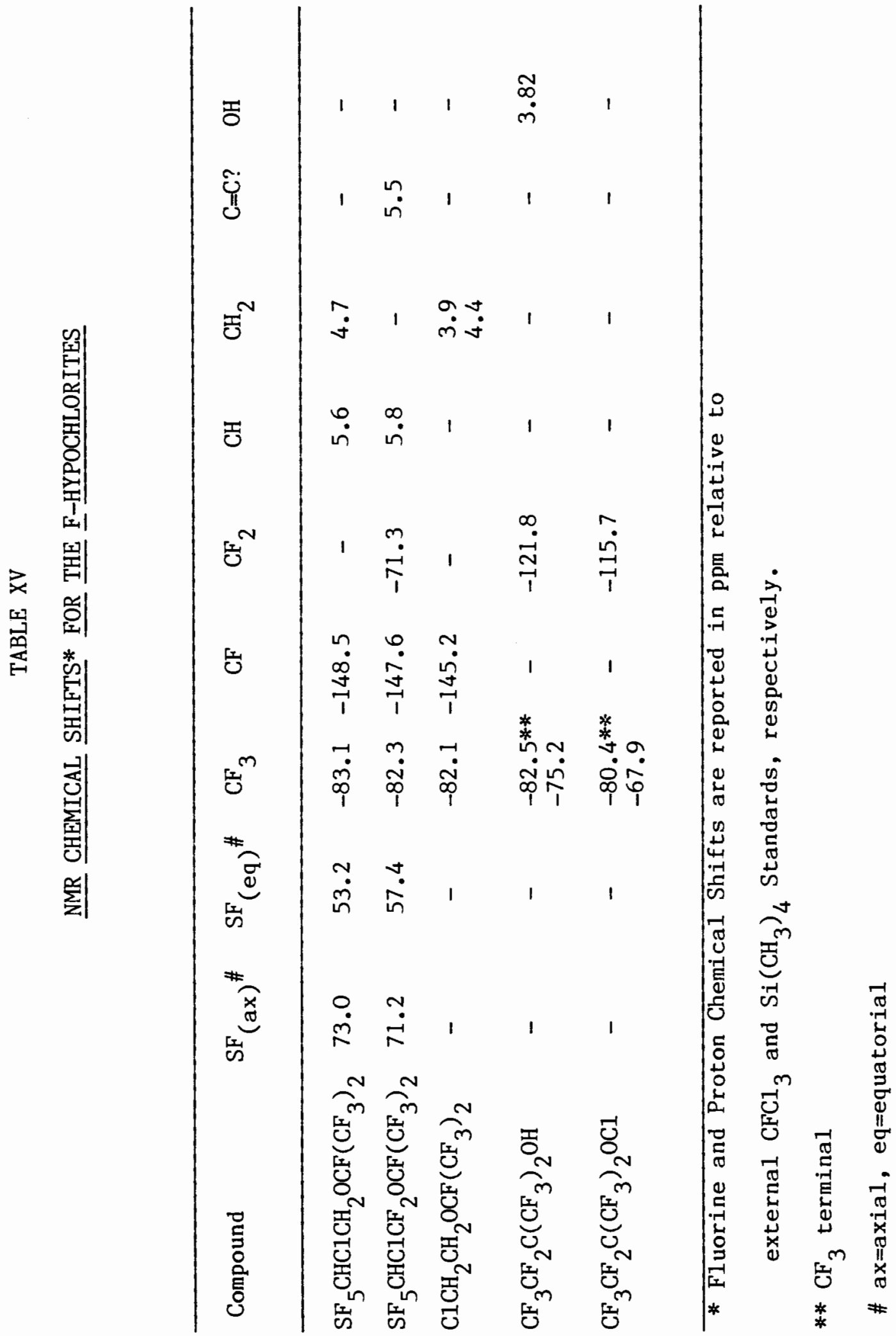




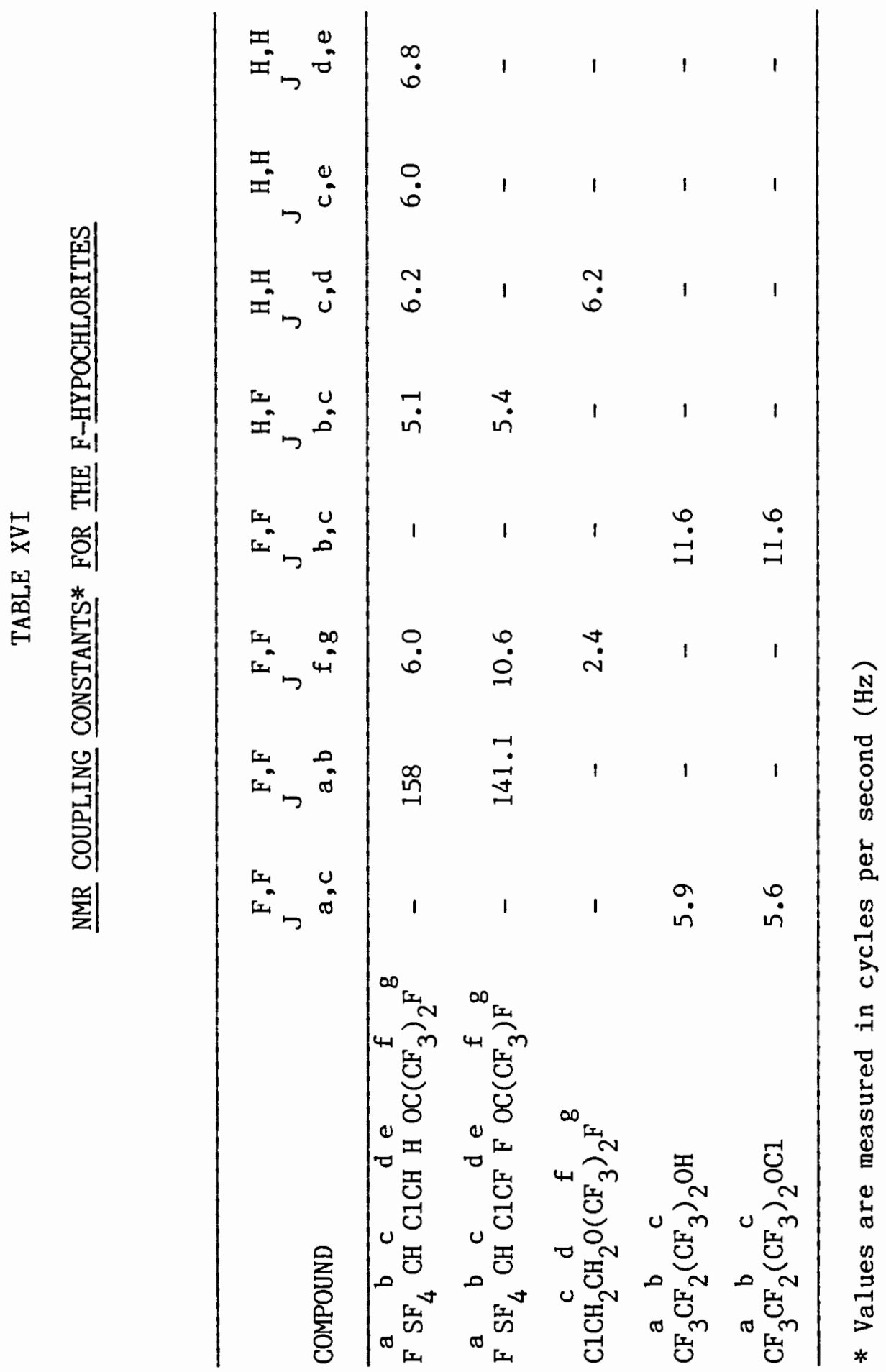


the parent alcohol. The chemical shifts were found for the compound: $\mathrm{CF}_{3}{ }^{\mathrm{a}} \mathrm{CF}_{2}{ }^{\mathrm{b}} \mathrm{C}\left(\mathrm{CF}_{3}{ }^{\mathrm{C}}\right)_{2} \mathrm{OCl}$ at $\phi-80.4\left(\mathrm{~F}^{\mathrm{a}}\right)$, $\phi-67.9\left(F^{c}\right)$ and $\phi-115.7\left(F^{b}\right)$ respectively with relative areas of $3.4: 6.3: 2.0$ (theor: $3.0: 6.0: 2.0$ ) respectively. The coupling constants were $J_{b-c}=11.6 \mathrm{~Hz}$ and $J_{a-c}=5.6$ $\mathrm{Hz}$.

Summary/conclusion.

Prior to this study, 1ittle was known concerning the chemistry of the heptafluoroisopropyl hypochlorite, i- $\mathrm{C}_{3} \mathrm{~F}_{7} \mathrm{OC} 1$. We have found that with hydrocarbon olefins new fluorinated ethers are formed. These new ethers were clear and easily distillable liquids and were found to be hydrolytically stable. All of the products were formed unidirectionally as confirmed by the NMR spectra (see discussion section).

In undertaking this study, it was our hope that the heptafluoroisopropyl hypochlorite would react with metal and non-metal systems to provide new and interesting metal complexes. Our results with $\mathrm{Hg}, \mathrm{I}_{2}$, and $\mathrm{TiCl}_{4}$ strongly suggest that fluorination and decomposition reactions occurred leading to products that were not fully characterized. In olefin reactions, however, $i-\mathrm{C}_{3} \mathrm{~F}_{7} \mathrm{OCl}$ was a useful reagent and new fluorinated ethers were synthesized and characterized.

The preparation of the new perfluoro-t-amyl 
hypochlorite, $\mathrm{CF}_{3} \mathrm{CF}_{2} \mathrm{C}\left(\mathrm{CF}_{3}\right)_{2} \mathrm{OCl}$, was an important aspect of this study. It is hoped that $\mathrm{CF}_{3} \mathrm{CF}_{2} \mathrm{C}\left(\mathrm{CF}_{3}\right)_{2} \mathrm{OCl}$ will provide a great number of perfluoro-t-amyl derivatives and in related reactions with olefins, will provide a route to a wide variety of fluorinated ethers through oxidative addition reactions.

\section{Recommendations.}

While the reaction of $\mathrm{i}-\mathrm{C}_{3} \mathrm{~F}_{7} \mathrm{OCl}$ with metal and non-metal systems did not provide the desired complexes (due to possible fluorine migration and decomposition), much information was obtained on the chemistry of this hypochlorite. It is hoped that future studies will explore the possibility of using $\mathrm{i}-\mathrm{C}_{3} \mathrm{~F}_{7} \mathrm{OCl}$ in fluorination reactions.

The chemical properties of the new perfluoro-t-amyl hypochlorite, $\quad \mathrm{CF}_{3} \mathrm{CF}_{2} \mathrm{C}\left(\mathrm{CF}_{3}\right)_{2} \mathrm{OCl}$, have not been fully investigated. Information obtained from its few reactions performed is promising and it is my belief that future workers will find this reagent useful in hypochlorite chemistry. 
REFERENCES

(1) R. J. French, L. Hedberg, K. Hedberg, G. L. Gard, and B. M. Johnson, Inorg. Chem., 22, 892 (1983).

(2) P. J. Green, B. M. Johnson, T. M. Loehr and G. L. Gard, Inorg. Chem., 21, 3562 (1982).

(3) H. B. Davis, R. M. Sheets, W. W. Paudler and G. L. Gard, Heterocycles, 22, 2029 (1984).

(4) G. L. Gard, Portland State University, personal communication, (1986).

(5) M. Mchughes, R. D. Willet, H. B. Davis and G. L. Gard, Inorg. Chem., 25, 427 (1986).

(6) E. J. Jacob, L. Hedberg, H. Davis and G. L. Gard, J. Physica1 Chem., 88, 1935 (1984).

(7) S. D. Brown, T. M. Loehr and G. L. Gard, J. Chem. Physics, 64, 260 (1976).

(8) A. G. Sharpe, A. A. Woolf, J. Chem. Soc., 798 $(1951)$.

(9) R. B. Johannesen and H. C. Krauss, J. Chem. Soc., 2094 (1964).

(10) H. C. Clark and Y. N. Sadana, Canad. I. Chem., 42, 50 (1964).

(11) J. S. Basi, D. C. Bradley and M. H. Chisholm, J. Chem. Soc $(\underline{A})$., 1433 (1971).

(12) E. C. Alyea, J. S. Basi, D. C. Bradley and M. H. Chisholm, J. Chem. Soc (A)., 772 (1971).

(13) M. Hagihara and H. Yamazaki, J. Am. Chem. Soc., 81, 3160 (1959).

(14) W. V. Rochart, J. N. Gerlach and G. L. Gard, Inorg. Chem., 9, 998 (1970).

(15) G. R. Dyrkacz, Ph.D., University of Illinois, 
University Microfilms.

(16) D. C. Bradley, Adv. Inorg. Chem. and Radiochem., 15, 259 (1972).

(17) D. C. Bradley and M. J. Hillyer, Trans. Faraday Soc., $\underline{62}, 23882(1966)$.

(18) W. Wardlaw and D. C. Bradley, Nature, 6ㅜ 165 (1950).

(19) K. B. Wiberg and G. Foster, Chem. Ind. (London), 108 (1961).

(20) D. C. Bradley, Coord. Chem. Rev., 2., 299 (1967).

(21) I. D. Varma and R. C. Mehrota, J. Chem. Soc., 2966 (1960).

(22) D. E. Gould, L. R. Anderson, D. E. Young and W. B. Fox, I. Am. Chem. Soc., 91, 1310 (1969).

(23) D. E. Young, L. R. Anderson, D. E. Gould and W. B. Fox, J. Am. Chem. Soc., 92, 2313 (1970).

(24) C. J. Schack and W. Maya, J. Amer. Chem. Soc., 91 , 2902 (1969).

(25) D. E. Young, L. R. Anderson and W. B. Fox, Inorg. Chem., 9, 2602 (1970).

(26) D. E. Young, L. R. Anderson and W. B. Fox, Inorg. Nucl. Chem. Lett., 6, 341 (1970).

(27) JoAnn M. Canich, G. L. Gard and J. M. Shreeve, Inorg. Chem., 23, 441 (1984).

(28) S. D. Morse, K. A. Laurence, G. H. Sprenger and J. M. Shreeve, J. Fluorine Chem., 11, 327 (1978).

(29) L. R. Anderson, D. E. Young, D. E. Gould, R. Juurik-Hogan, D. Nnechterlein and W. B. Fox, J. Org. Chem., 35, 3730 (1970).

(30) P. Graham and V. Weinmayr, J. Org. Chem., 31, 957 (1966).

(31) J. M. Canich, Masters thesis, Portland State University (1984). 
(32) PCR Report, PCR Inc., Ju1y (1973).

(33) W. H. Burton and L. W. Breed, J. Org. Chem., 31 , 4229 (1966).

(34) J.A. Kemp \& Co., U..$\underline{S}$. Patent, 974,612 (1964).

(35) J. Rocek and A. E. Radkowsky, J. Amer. Chem. Soc., 95, 7123 (1973).

(36) K. B. Wiberg and R. Schaefer, J. Amer. Chem. Soc., 91, 933 (1969).

(37) J. Rocek and Chiu-Sheung Ng, J. Amer. Chem. Soc., 96, 1522 (1974).

(38) M. Rahman and J. Rocek, J. Amer. Chem. Soc., 93, 5455 (1971).

(39) Pavia, Lampman, and Kriz, Introductory Spectroscopy. Holt Rhinhart, ed., Saunders Golden Sunburst Series, (1979).

(40) C. J. Marsden, L. Hedberg and K. Hedberg, Inorg. Chem., 21, 1115 (1982).

(41) C. D. Garner, R. Mather and M. F. A. Dove, J. Chem. Soc., Chem. Commun., 633 (1973).

(42) I. R. Beattie, C. J. Marsden and J. S. Ogden, J. Chem. Soc., Dalton Trans., 535 (1980).

(43) E. G. Hope, P. J. Jones, W. Levason, J. S. Ogden, M. Tajik and J. W. Turff, J. Chem. Soc., Dalton Trans., 1443 (1985).

(44) R. J. Terjeson, K. D. Gupta, R. M. Sheets, G. L. Gard and J. M. Shreeve. Accepted for publication in Revue de Chimie Minera1, $00,1986$.

(45) K. K. Johri and D. D. DesMarteau, J. Org. Chem., 48, $242(1983)$.

(46) W. A. Kamil, F. Haspe1-Hentrich and J. M. Shreeve, Inorg. Chem., 25, 376 (1986).

(47) L. H. Cross, G. Cushing, H. L. Roberts, Spectrochim. Acta, 17, 344 (1981).

(48) K. Nakamato, Infrared Spectra of Inorganic and 
Coordination Compounds, 2nd Ed., Wiley Interscience, NY, $220(1970)$.

(49) D. G. Weiblen, "The Infrared Spectra of Fluorocarbons and Related Compound", Fluorine Chemistry, Vo1. 2 , J. H. Simons, ed., Academic Press Inc., NY, $4 \frac{2}{5} 6$ (1954).

(50) M. Stacey, J. C. Tatlow and A. G. Sharpe, Advances in Fluorine Chemistry, Vol. 4, Butterworth \& Co., Washington, 259 (1965). 
APPENDIX

INFRARED SPECTRA

COMPOUND

PAGE

$1 \mathrm{CrF}_{4} \cdot \cdot \cdot \cdot \cdot \cdot \cdot \cdot \cdot \cdot \cdot \cdot \cdot \cdot \cdot \cdot \cdot \cdot \cdot \cdot 101$

$2 \mathrm{CF}_{3} \mathrm{CH}_{2} \mathrm{OH}$ with $\mathrm{Cr}\left(\mathrm{OC}_{4} \mathrm{H}_{9}\right)_{4} \cdot$. . . . . . . . 102

$3\left(\mathrm{CF}_{3}\right)_{2} \mathrm{CHOH}$ with $\mathrm{Cr}\left(\mathrm{OC}_{4} \mathrm{H}_{9}\right)_{4}(\mathrm{a} \& \mathrm{~b}) \cdot \cdot \cdot \cdot \cdot \cdot \cdot 103$

$4\left(\mathrm{CF}_{3}\right)_{3} \mathrm{COH}$ with $\mathrm{Cr}\left(\mathrm{OC}_{4} \mathrm{H}_{9}\right)_{4}$. . . . . . . . 104

$5 \mathrm{C}_{6} \mathrm{~F}_{5} \mathrm{OH}$ with $\mathrm{Cr}\left(\mathrm{OC}_{4} \mathrm{H}_{9}\right)_{4} \cdot$. . . . . . . . . 105

$6\left(\mathrm{C}_{6} \mathrm{H}_{5}\right) \mathrm{SiOH}$ with $\mathrm{Cr}\left(\mathrm{OC}_{4} \mathrm{H}_{9}\right)_{4} \cdot \cdot \cdot \cdot \cdot \cdot \cdot \cdot \cdot \cdot 106$

$7 \mathrm{HF}$ with $\operatorname{Cr}\left(\mathrm{OC}_{4} \mathrm{H}_{9}\right)_{4}$. . . . . . . . . . 107

$8 \mathrm{CF}_{3} \mathrm{COOAg}$ with $\mathrm{Cr}\left(\mathrm{OC}_{4} \mathrm{H}_{9}\right)_{4} \cdot . \cdot . \cdot . \cdot . \cdot . \cdot 108$

$9 \mathrm{CF}_{3} \mathrm{CH}_{2} \mathrm{OH}$ with $\mathrm{Cr}\left(\mathrm{NEt}_{2}\right)_{3} \cdot$. $\cdot$. . . . . . 109

$10\left(\mathrm{CF}_{3}\right)_{2} \mathrm{CHOH}$ with $\mathrm{Cr}\left(\mathrm{NEt}_{2}\right)_{3} \cdot \cdot \cdot \cdot \cdot \cdot \cdot \cdot \cdot \cdot \cdot 110$

$11 \mathrm{TiCl}_{4}$ with $\mathrm{i}-\mathrm{C}_{3} \mathrm{~F}_{7} \mathrm{OCl}$. . . . . . . . . . . . 111

$12 \mathrm{I}_{2}$ with $\mathrm{i}-\mathrm{C}_{3} \mathrm{~F}_{7} \mathrm{OCl}$. . . . . . . . . . . . 112

$13 \mathrm{Hg}$ with $\mathrm{i}-\mathrm{C}_{3} \mathrm{~F}_{7} \mathrm{OCl}$. . . . . . . . . . . . 113

$14 \mathrm{SF}_{5} \mathrm{CH}=\mathrm{CH}_{2}$ with $\mathrm{i}-\mathrm{C}_{3} \mathrm{~F}_{7} \mathrm{OCl}$. . . . . . . . . 114

$15 \mathrm{SF}_{5} \mathrm{CH}=\mathrm{CF}_{2}$ with $\mathrm{i}-\mathrm{C}_{3} \mathrm{~F}_{7} \mathrm{OCl}$. . . . . . . . . 115

$16 \mathrm{CH}_{2}=\mathrm{CH}_{2}$ with $\mathrm{i}-\mathrm{C}_{3} \mathrm{~F}_{7} \mathrm{OCl}$. . . . . . . . . 116

$17 \mathrm{CF}_{3} \mathrm{CF}_{2} \mathrm{C}\left(\mathrm{CF}_{3}\right)_{2} \mathrm{OH}$. $\cdot$. . . . . . . . . 117

$18 \mathrm{CF}_{3} \mathrm{CF}_{2} \mathrm{C}\left(\mathrm{CF}_{3}\right)_{2} \mathrm{OC} 1$. $\cdot . \cdot \cdot \cdot \cdot \cdot \cdot \cdot \cdot \cdot 18$ 


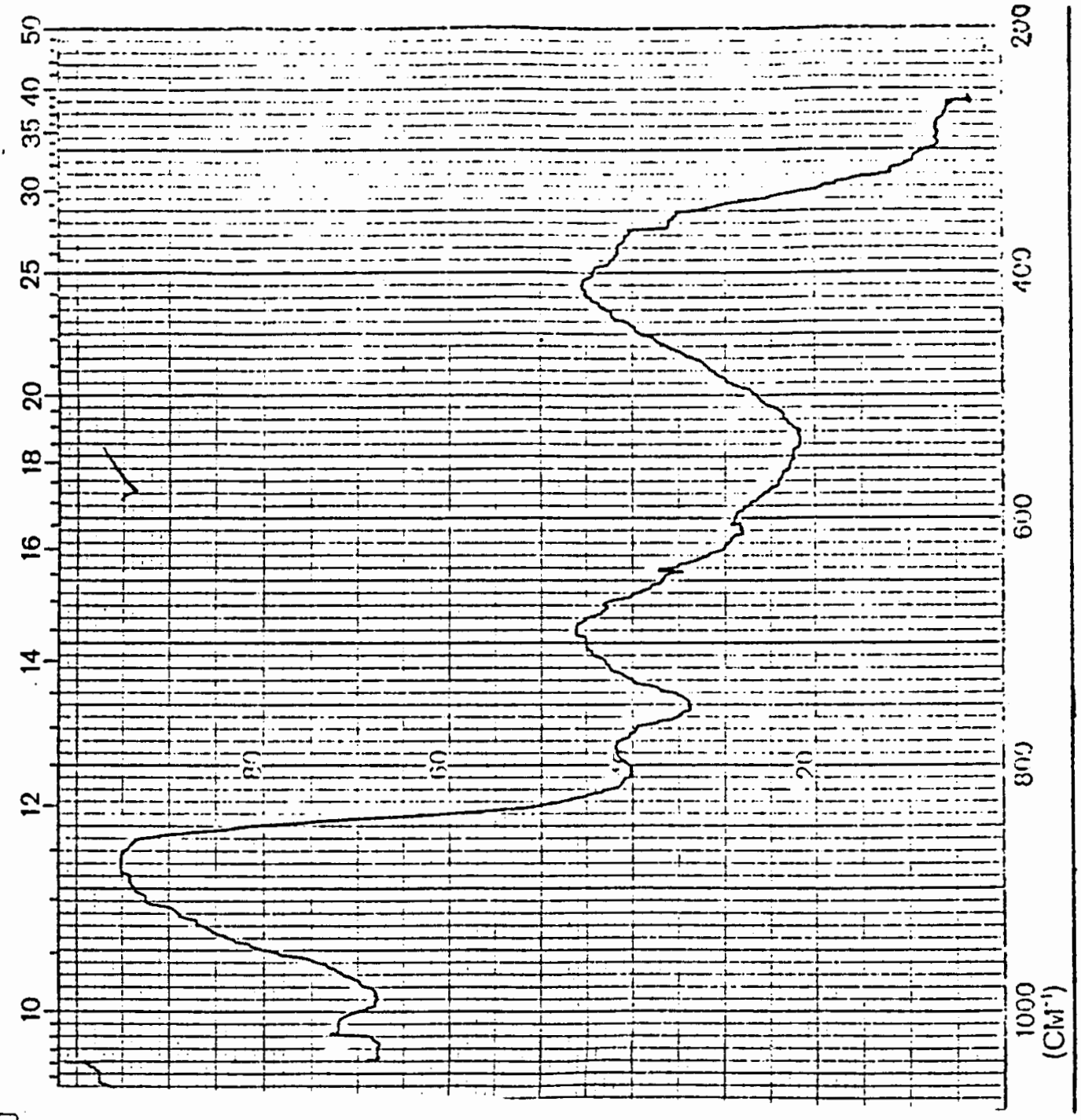

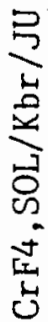




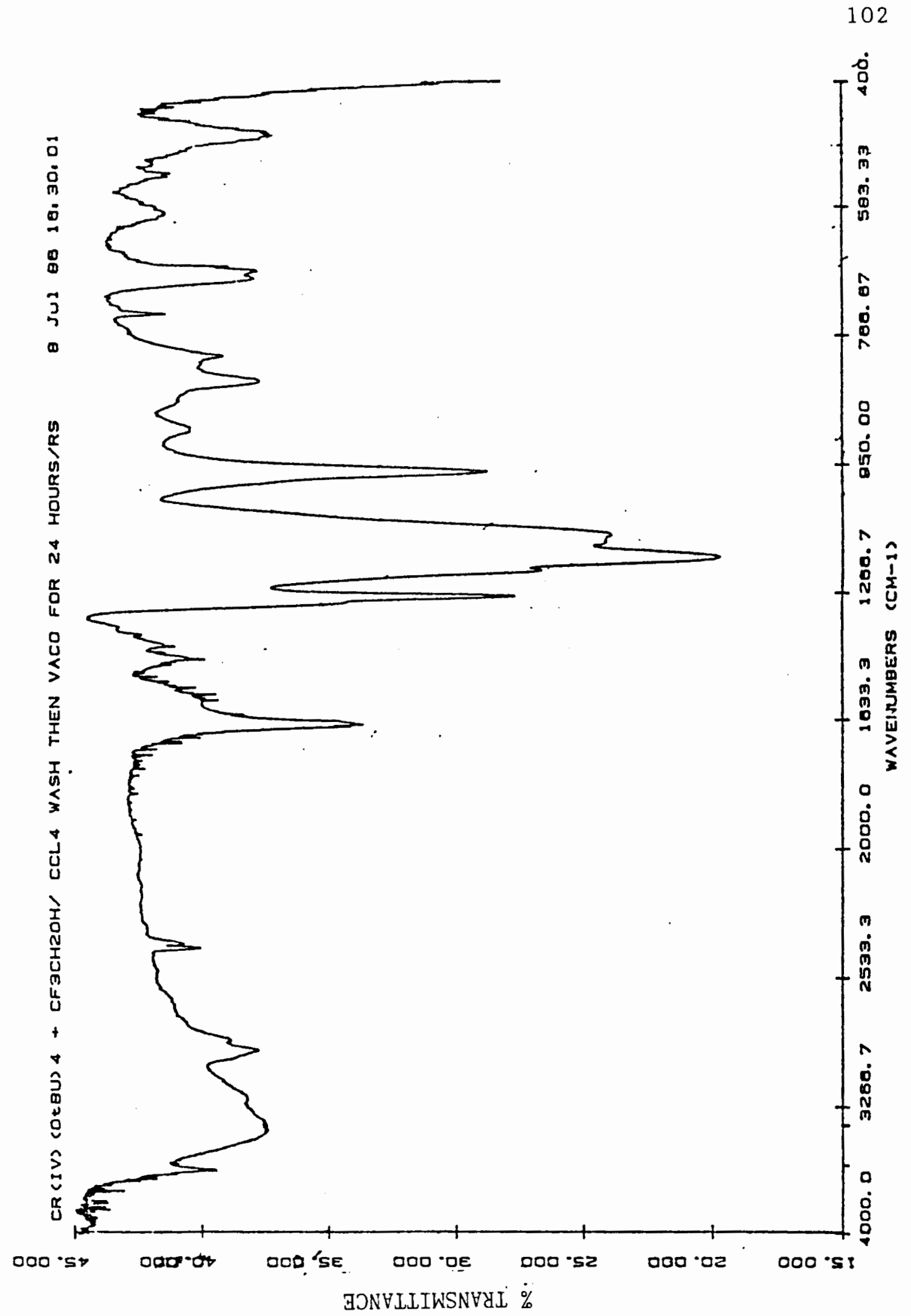



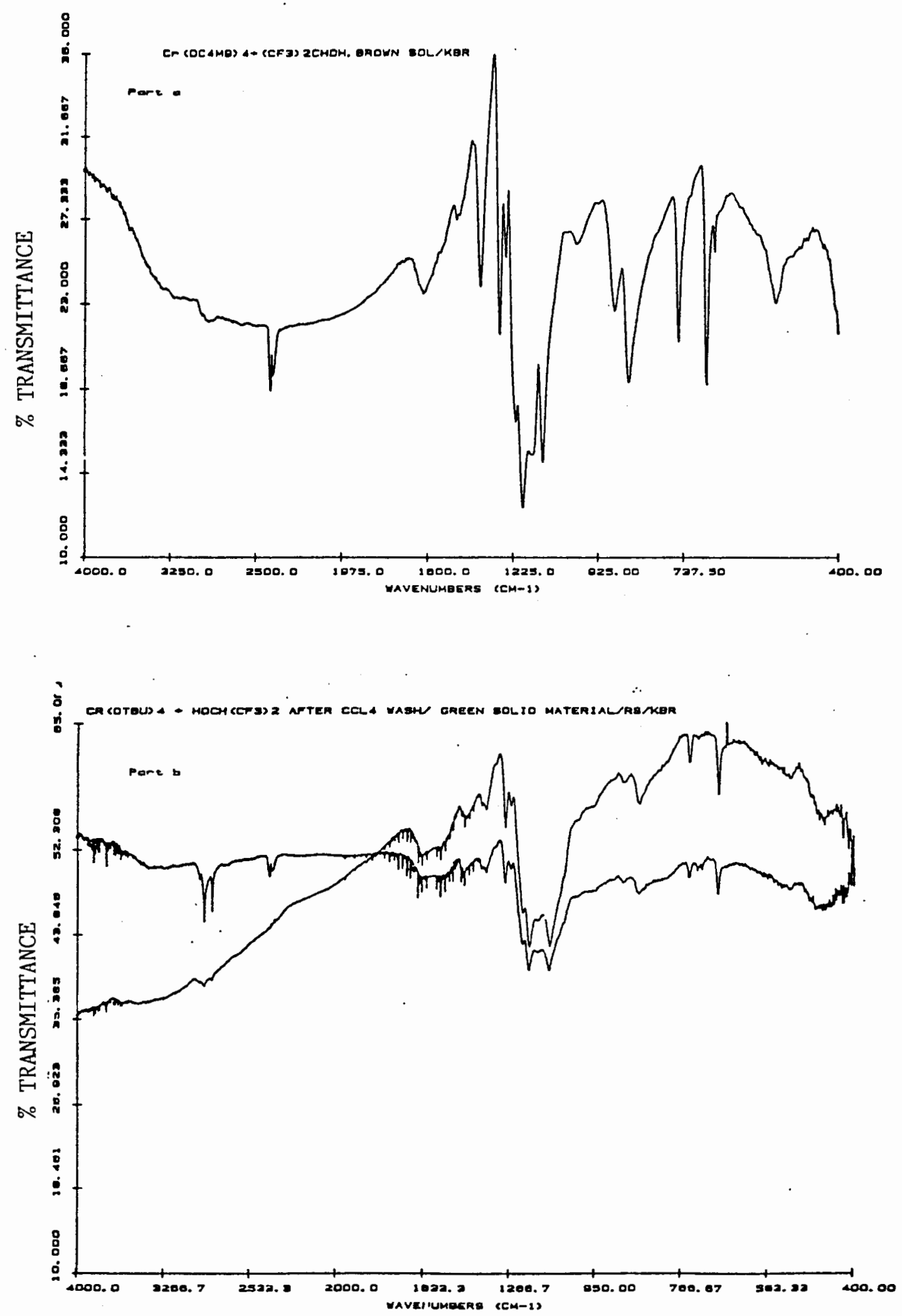


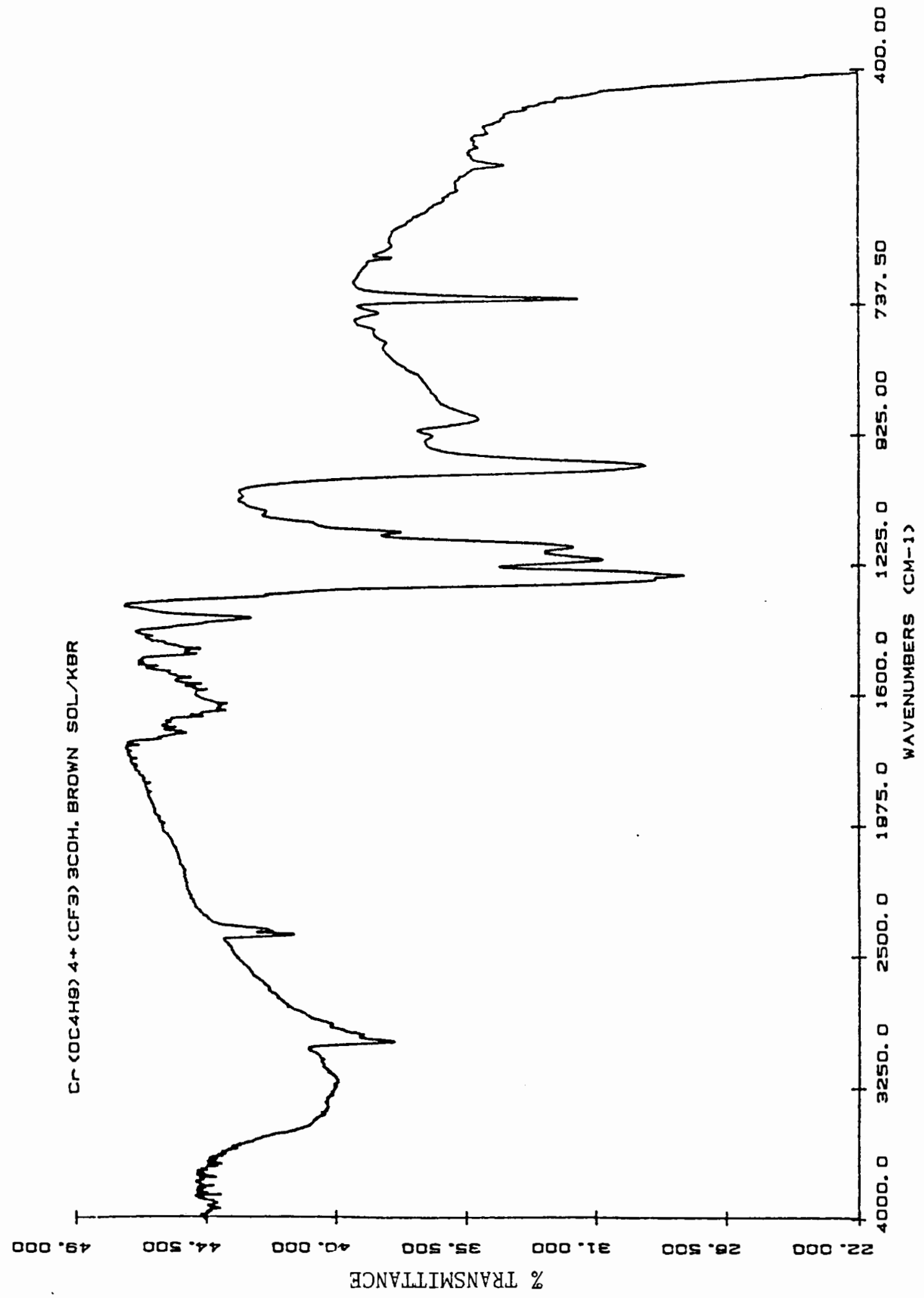




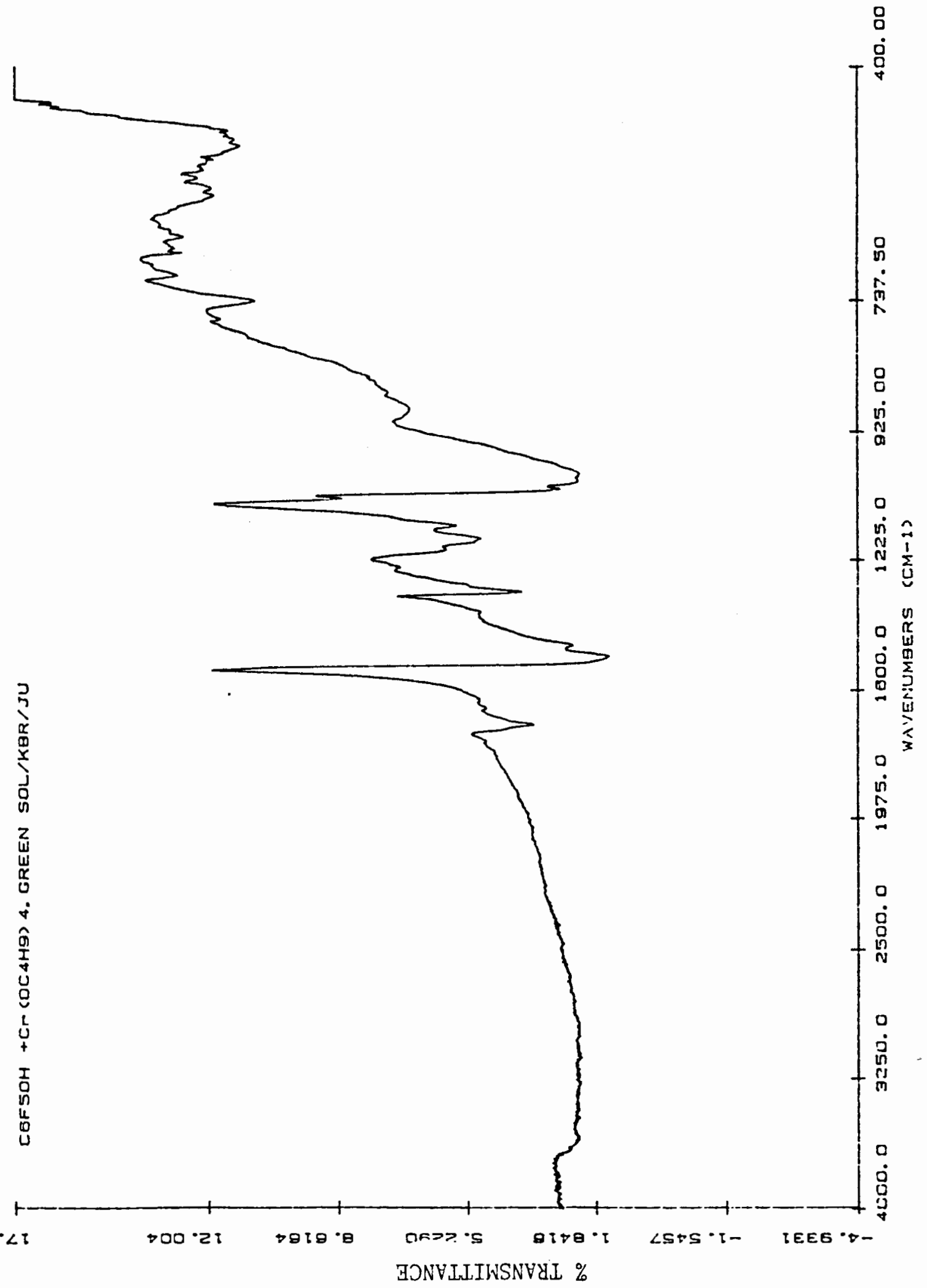




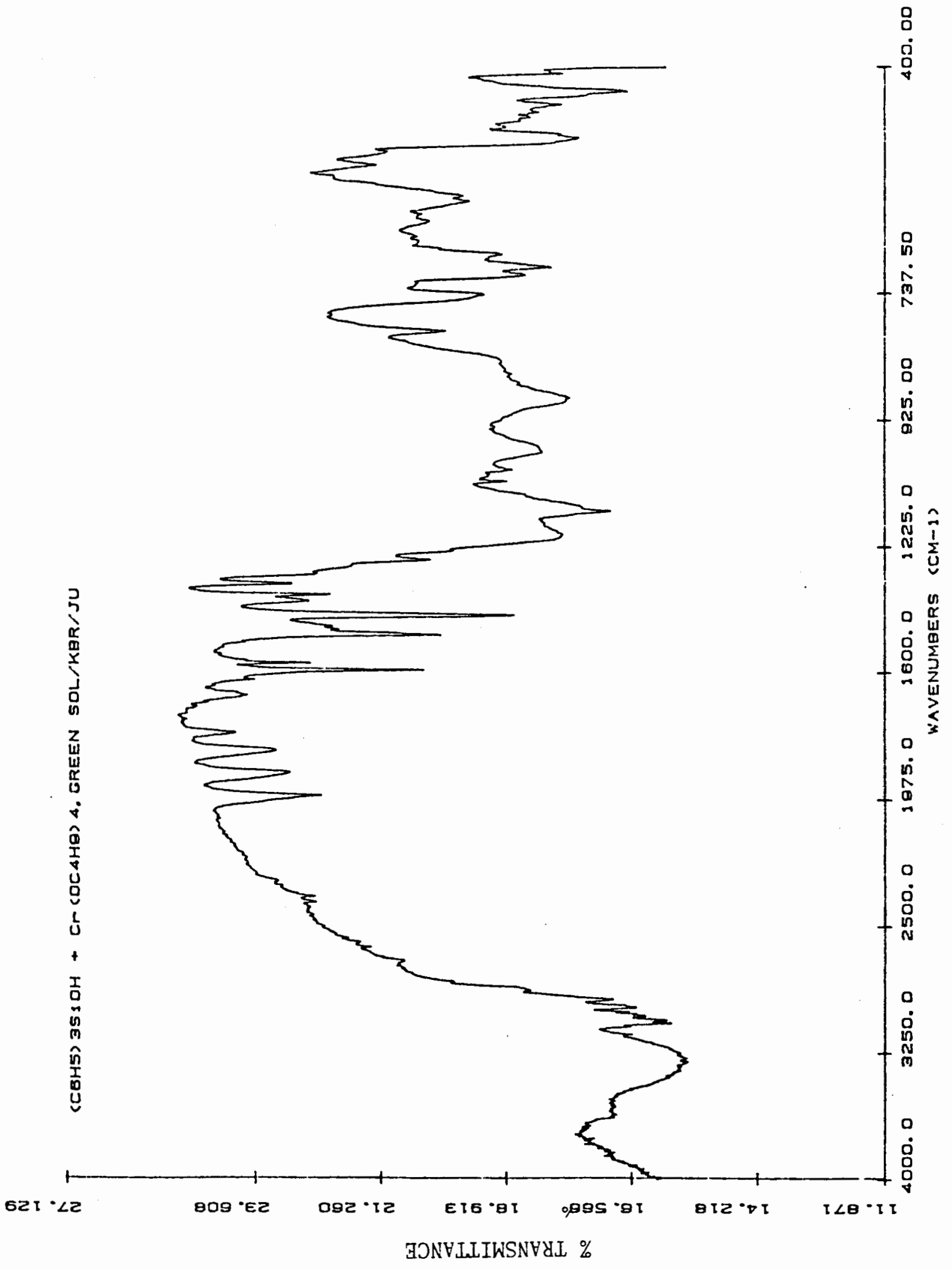




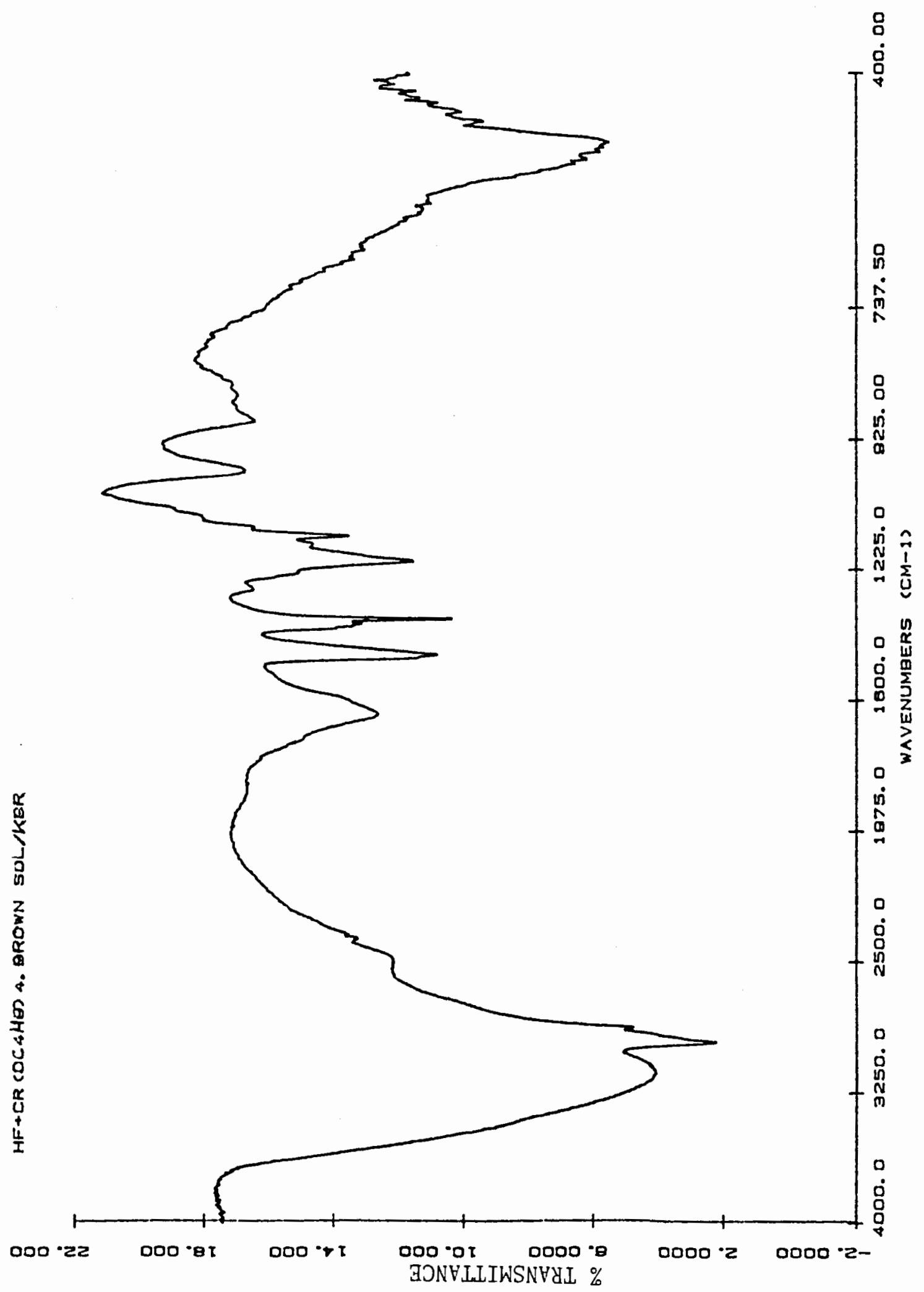




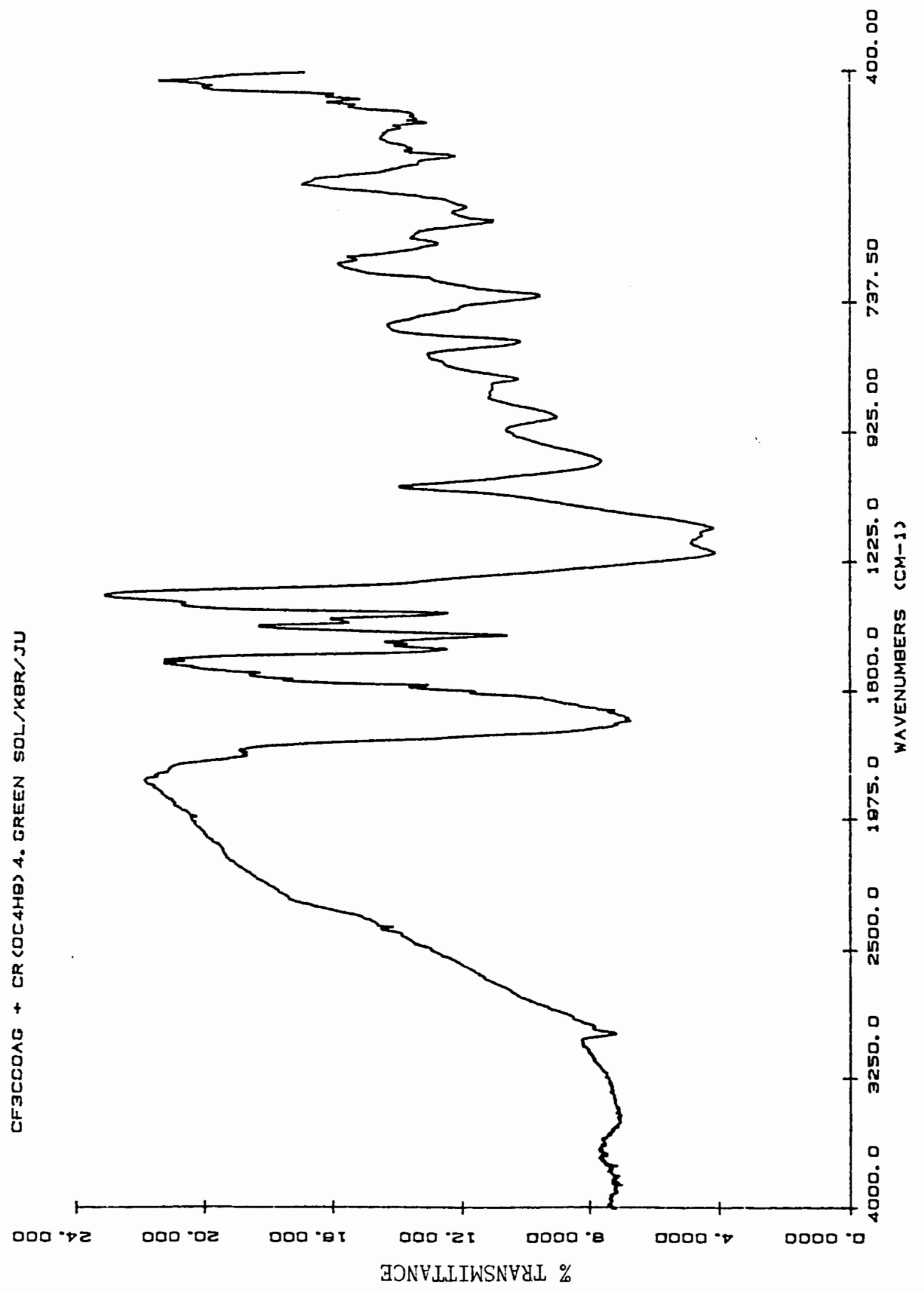




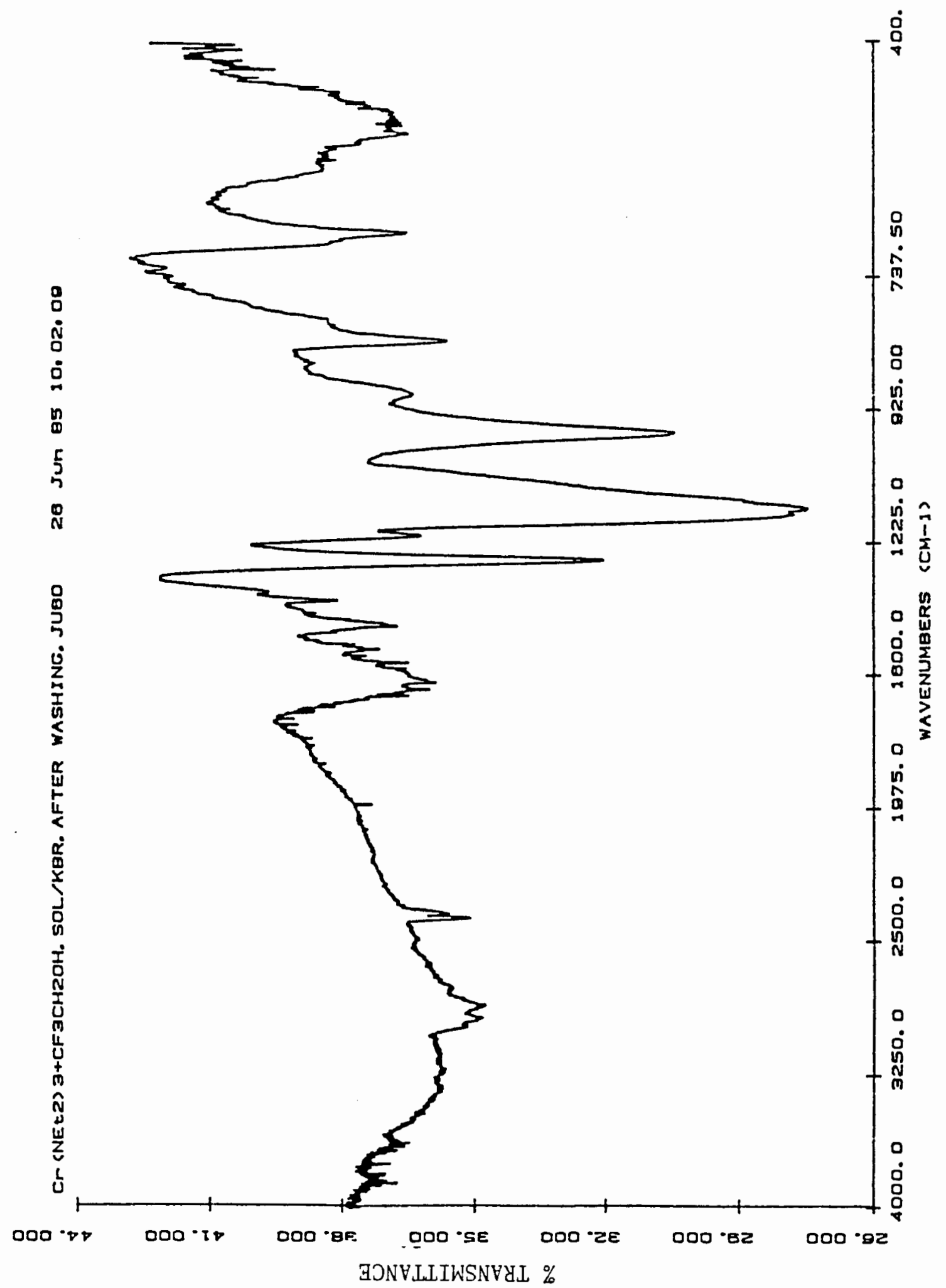



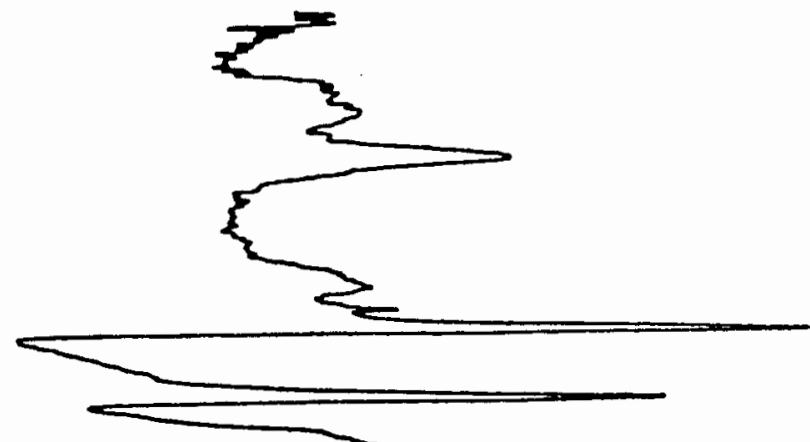

II

L

号

定

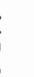

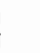

年

$000 \cdot+E \quad \angle 80 \cdot 82$
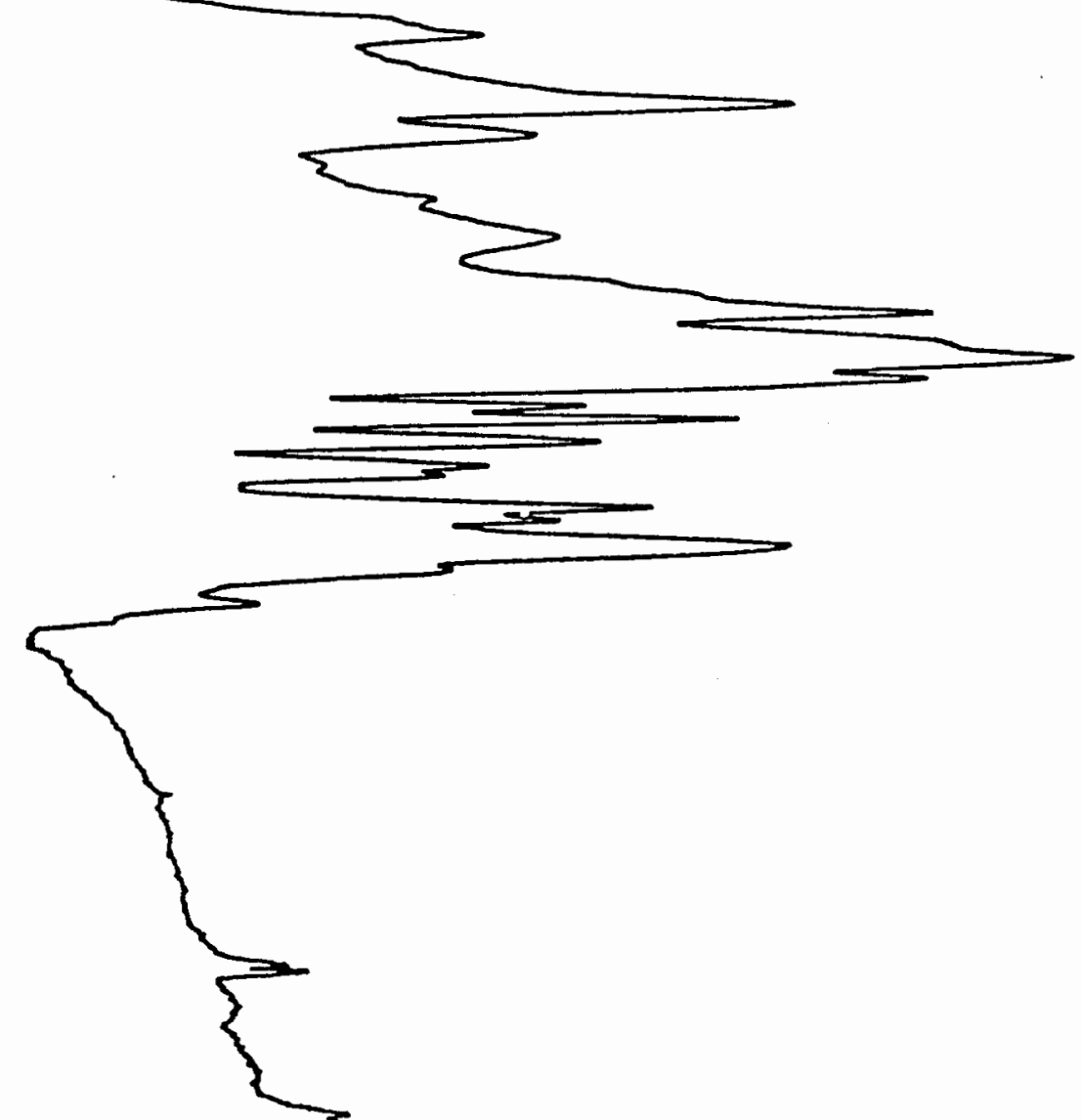

2

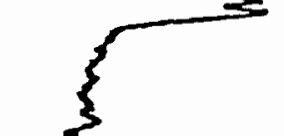

í

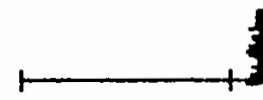




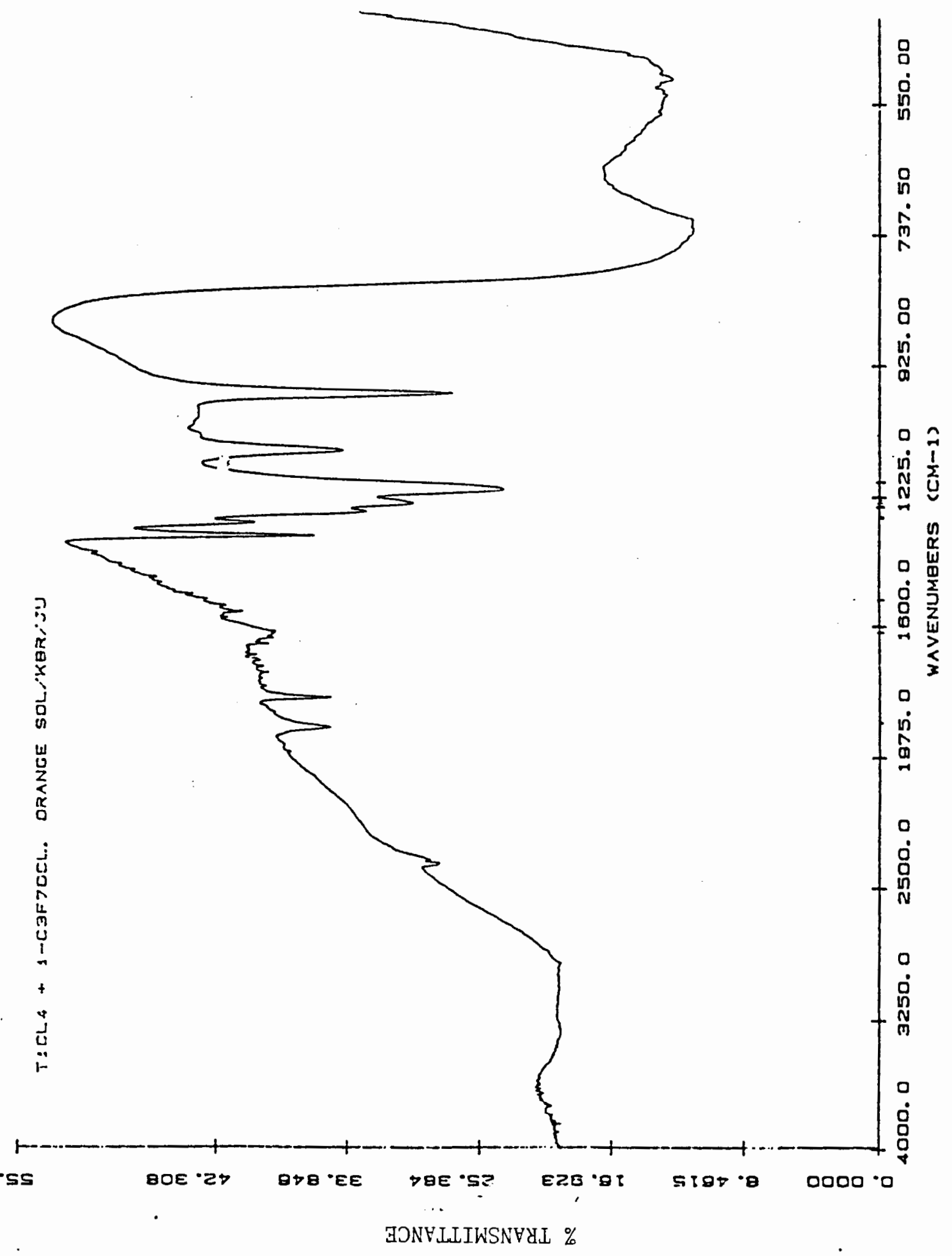




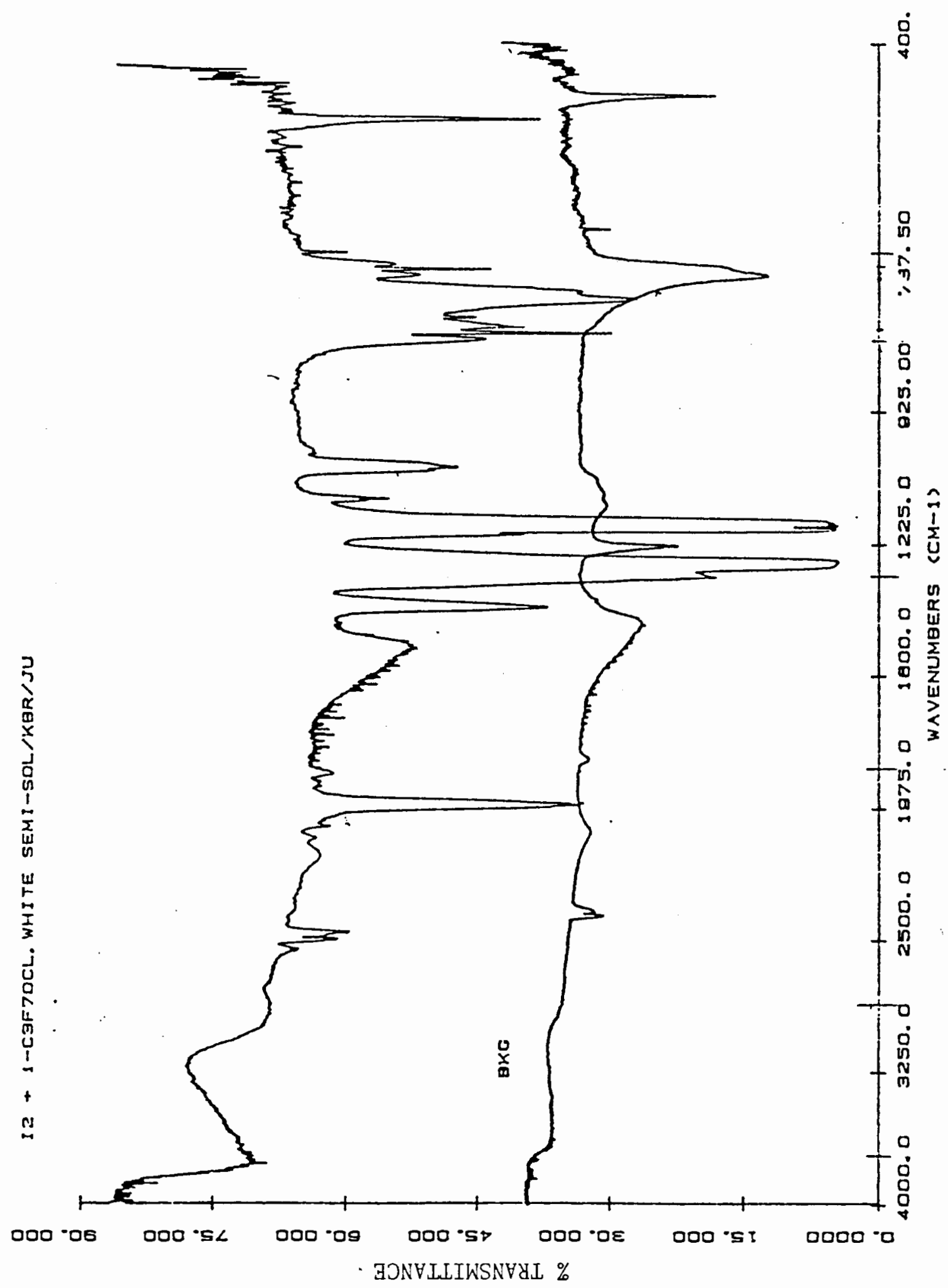




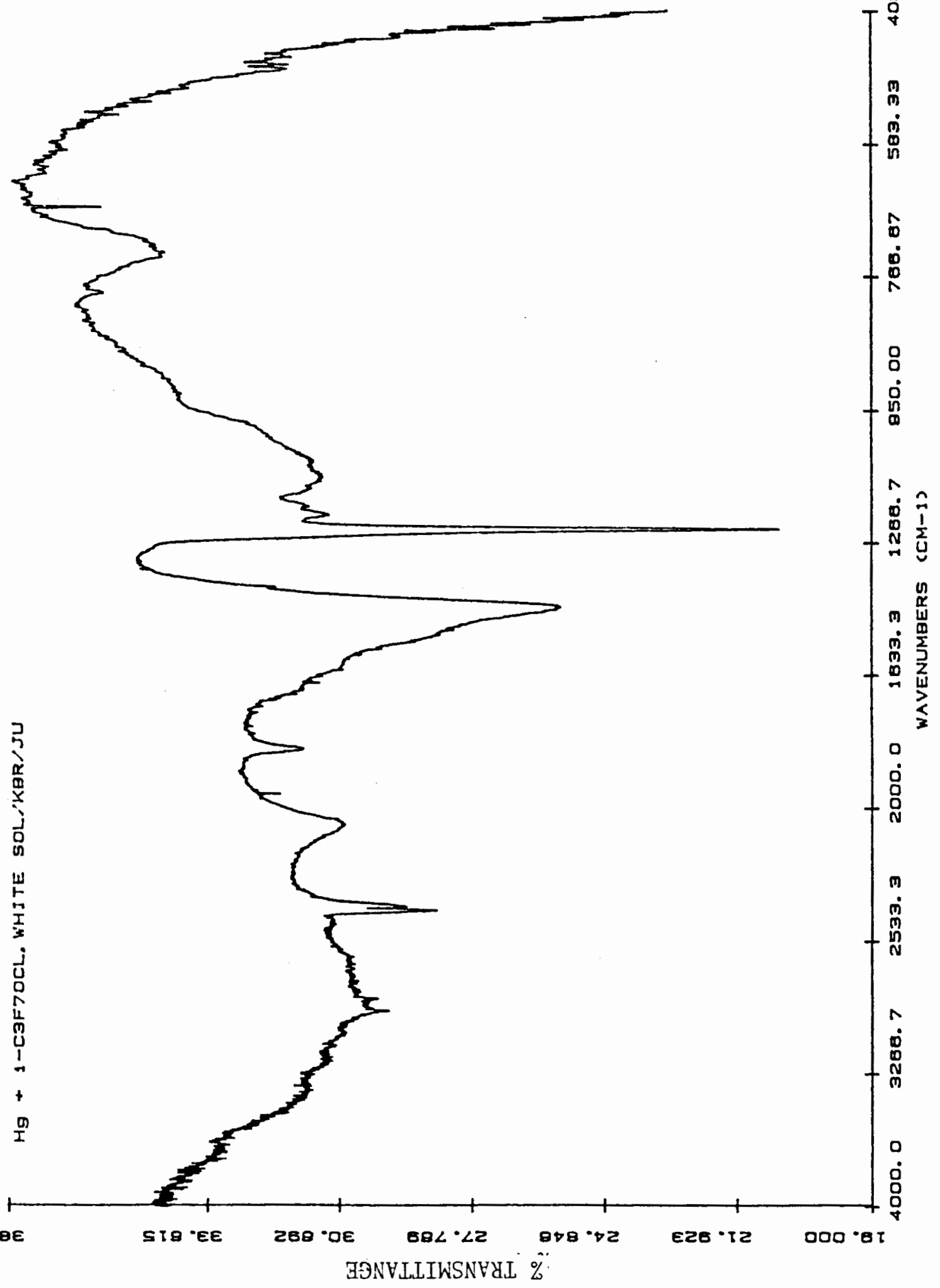


114

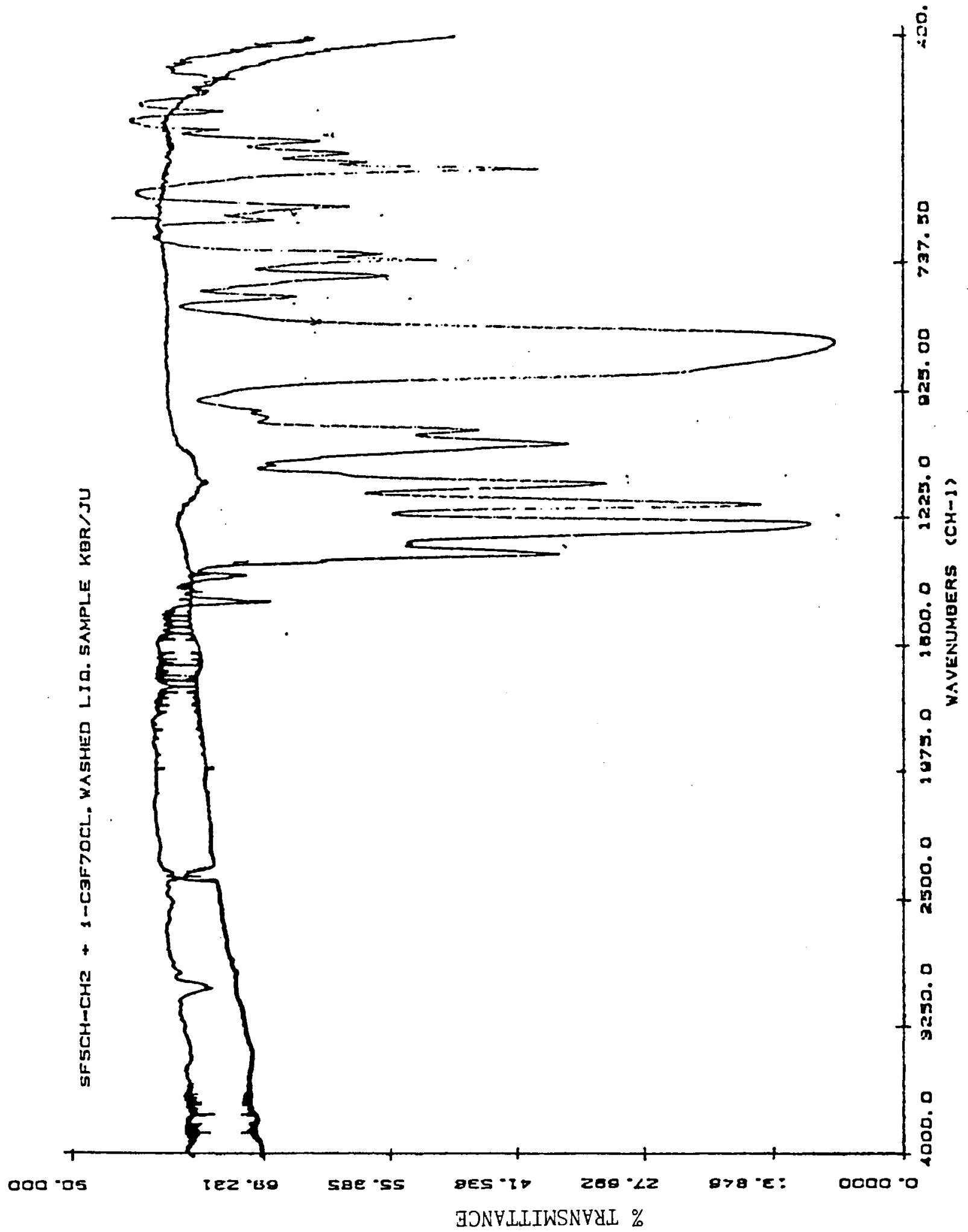


115

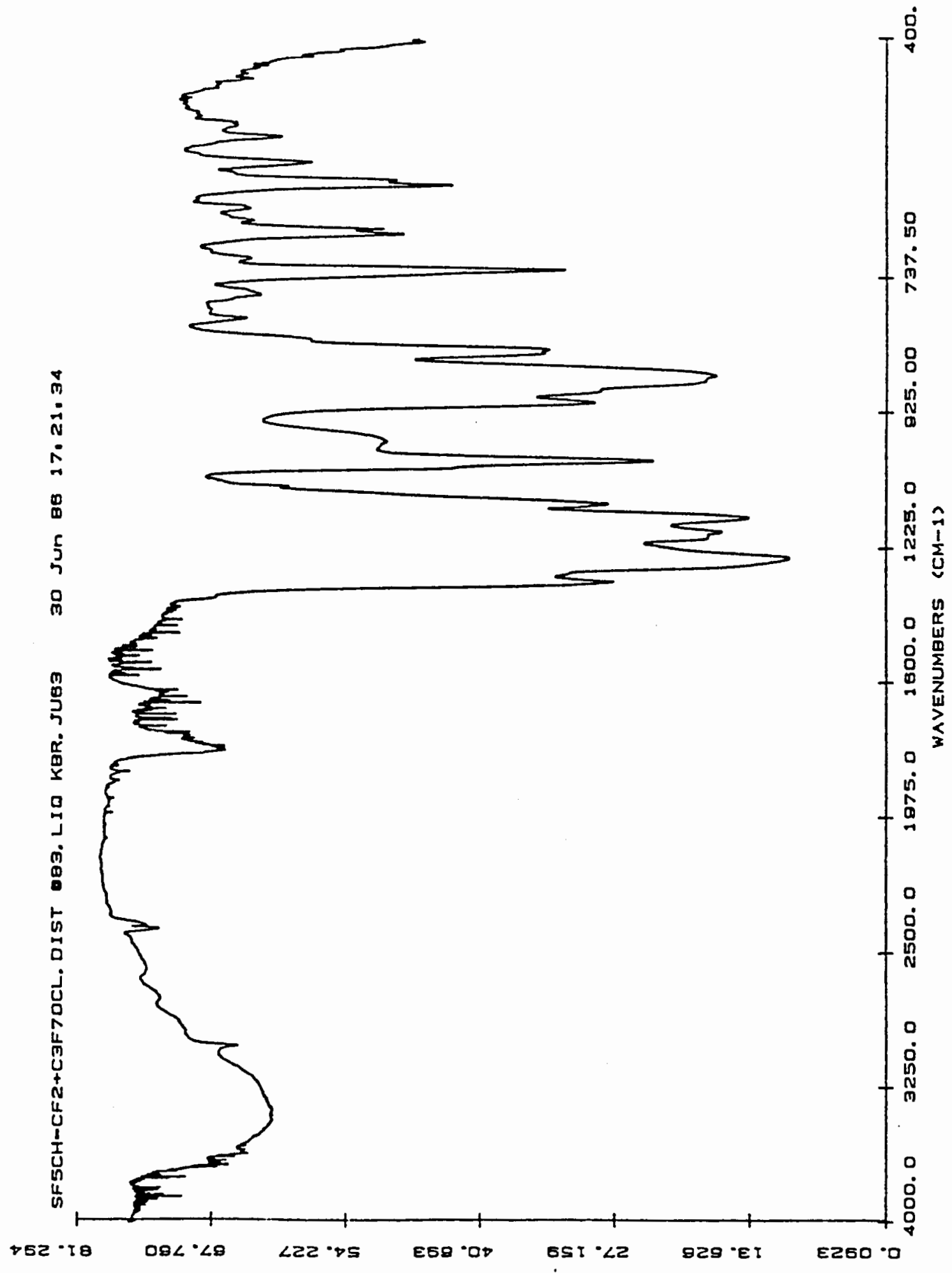




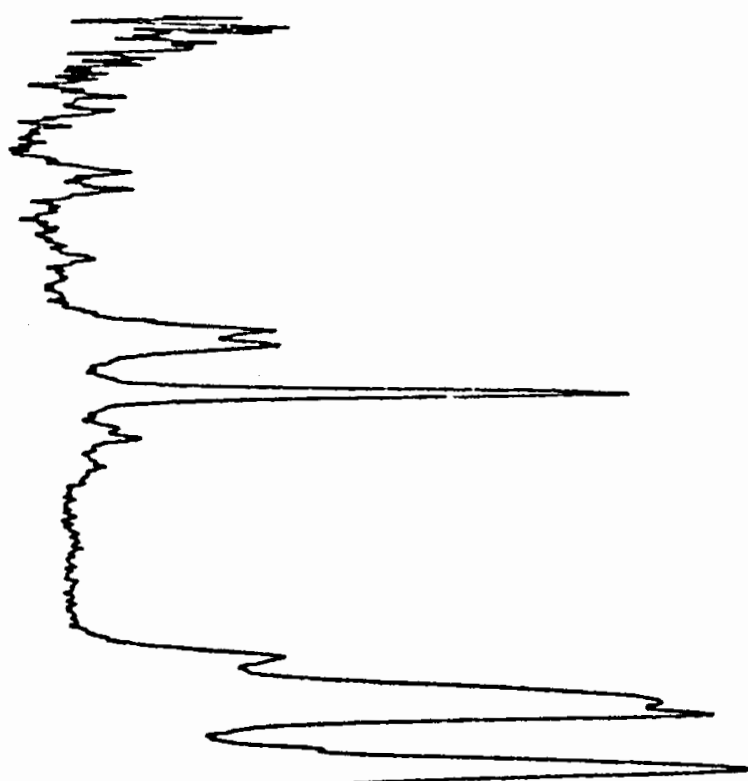

à
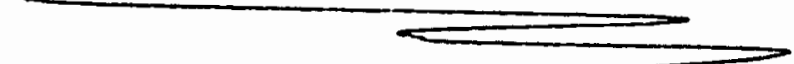

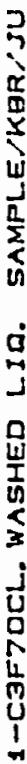

3

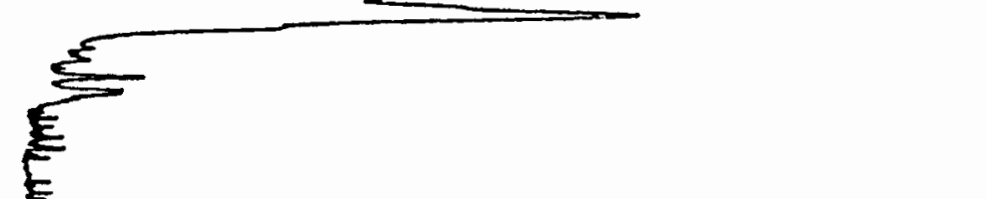

음

$+\stackrel{0}{N}$

$\stackrel{N}{\mathrm{I}}$

1
$I$
$I$
$\frac{1}{U}$
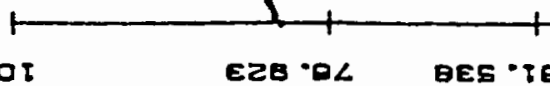

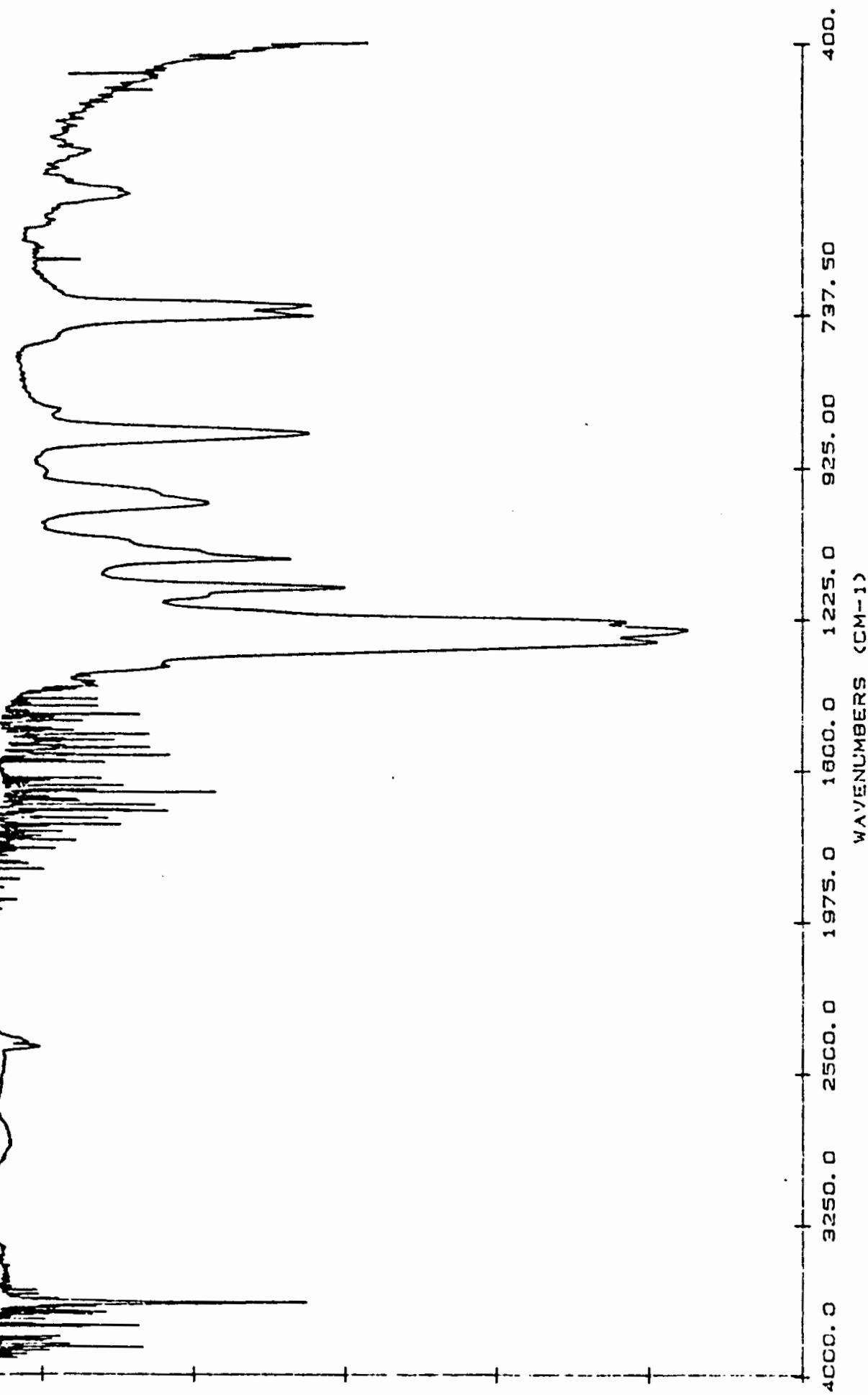


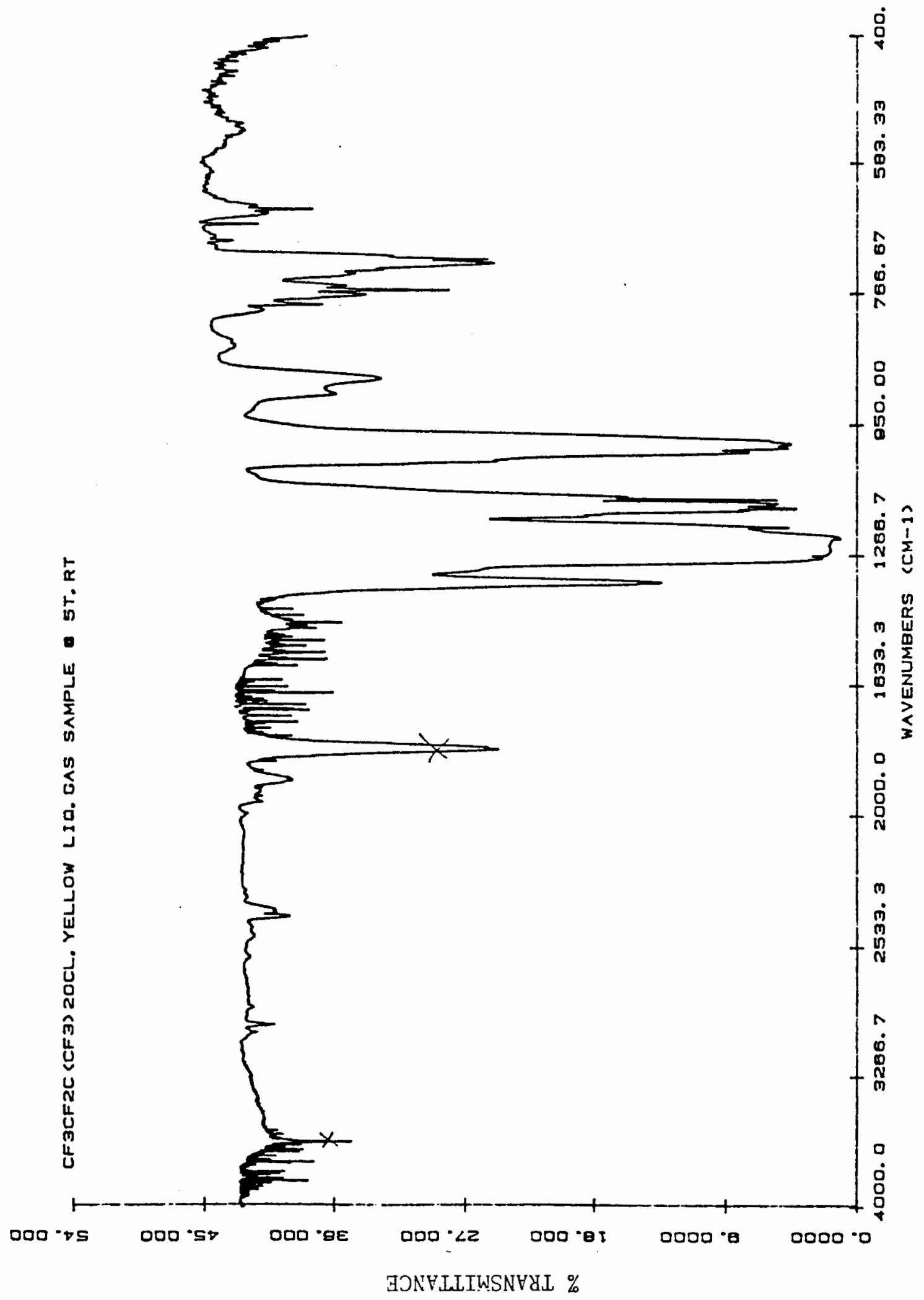

